\title{
Morocco Infrastructure Review
}

May 2020 (originally published in French in December 2019)

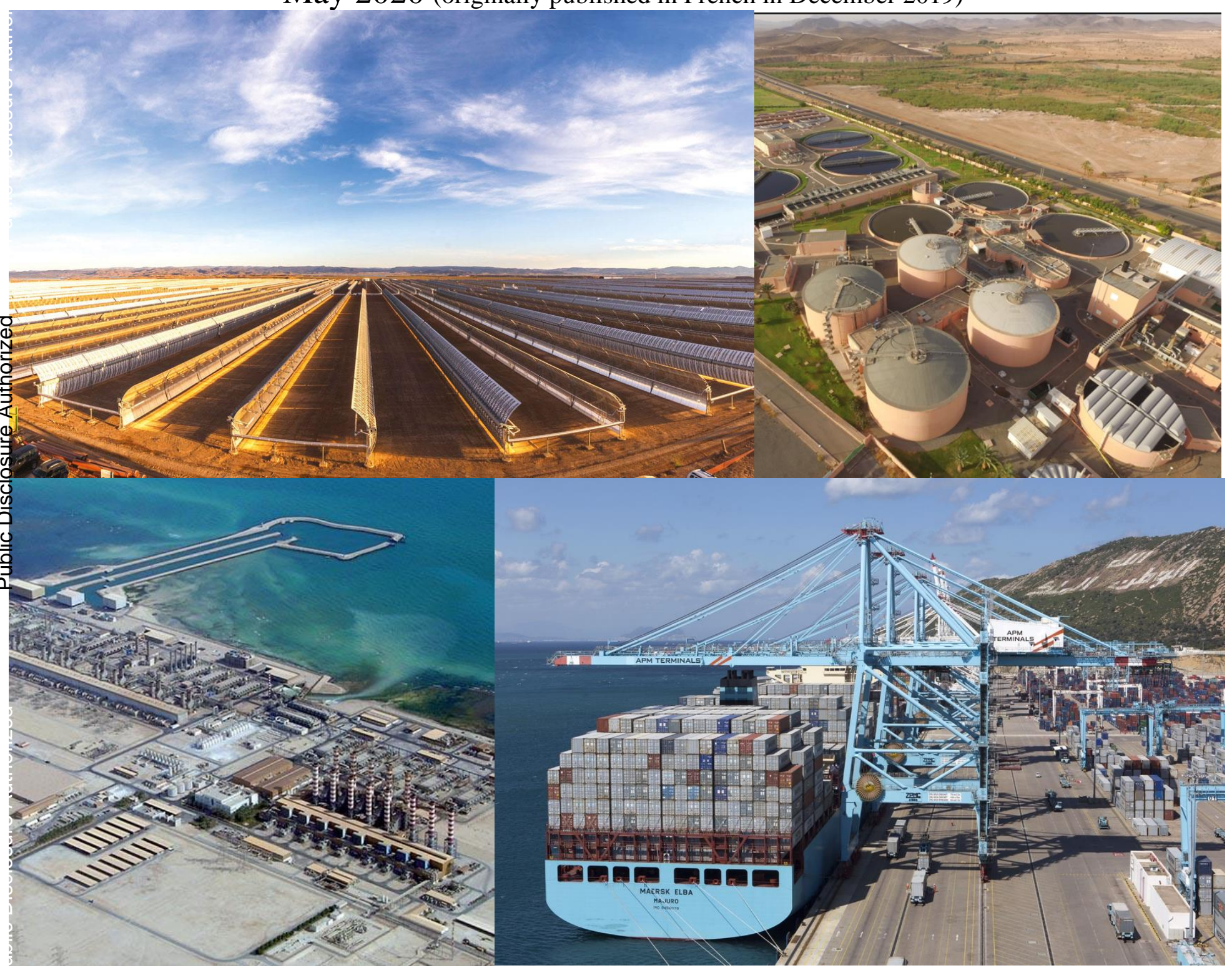

Final version 
(C) 2020 International Bank for Reconstruction and Development / The World Bank 1818 H Street NW, Washington, DC 20433

Telephone: 202-473-1000; Internet: www.worldbank.org

This work was originally published by the World Bank in French in 2019. In case of discrepancies, the original language should prevail.

This work is a product of the staff of The World Bank with external contributions. The findings, interpretations, and conclusions expressed in this work do not necessarily reflect the views of The World Bank, its Board of Executive Directors, or the governments they represent.

The World Bank does not guarantee the accuracy of the data included in this work. The boundaries, colors, denominations, and other information shown on any map in this work do not imply any judgment on the part of The World Bank concerning the legal status of any territory or the endorsement or acceptance of such boundaries.

\section{Rights and Permissions}

The material in this work is subject to copyright. Because The World Bank encourages dissemination of its knowledge, this work may be reproduced, in whole or in part, for noncommercial purposes as long as full attribution to this work is given.

Please cite the work as follows: 2020. Morocco Infrastructure Review.

World Bank, Washington D. C.

Any queries on rights and licenses, including subsidiary rights, should be addressed to World Bank Publications, The World Bank Group, 1818 H Street NW, Washington, DC 20433, USA; fax: 202-5222625; e-mail: pubrights@worldbank.org 


\section{Abbreviations and acronyms}

ABH Agences de bassins hydrauliques

ADD

Agence du développement digital

AdM

Autoroutes du Maroc

AMEE

ADM

Agence marocaine de l'efficacité énergétique

ANP

Autoroutes du Maroc

ANRE

Agence nationale des ports

ANRT

Autorité nationale de régulation de l'éléctricité

CAPEX

Agence nationale de réglementation des télécommunications

CNCP Commission nationale de la commande publique

CSP

Concentrated solar power

DEPP Direction des entreprises publiques et de la privatisation

GDP Gross domestic product

GWh Gigawatt hour

HCP Haut-commissaire au plan

ISP Internet service provider

ICT

IPP

LGV

information and communication technology

Ligne à grande vitesse

MASEN

MAD

Moroccan Agency for Sustainable Energy

MENA Middle East and North Africa

METLE Ministère de l'équipement, du transport, de la logistique et de l'Eau (Ministry of

MW

O\&M

ODA

Equipment, Transport, Logistics, and Water)

OECD

ONCF

ONDA

ONEE

OPEX

ORMVA

PERG

PIM

Megawatt

Operation and maintenance

Official development assistance

Organisation for Economic Co-operation and Development

Office national des chemins de fer

Office national des aéroports

Office national de l'électricité et de l'eau potable

Operating expenditure(s)

Offices régionaux de mise en valeur agricole

Public investment management

PNRR Programme national de routes rurales

PPP Public-private partnership

RAM Royal Air Maroc

SIE

Société d'investissement énergétique

SOE State-owned enterprise

USD United States dollars

USF Universal Service Fund

WDI

World Development Indicators 


\section{Acknowledgments}

The World Bank Group wishes to thank the Moroccan Government for the extensive cooperation extended during the preparation of this report. The Ministry of Economy and Finance (including the three departments: the Department of Public Enterprises and Privatization, the Directorate of Budget, and the Directorate of the Treasury and External Finance), the Ministry of General Affairs and Governance, the line ministries responsible for infrastructure and the main state-owned enterprises for infrastructure analyzed in this report provided detailed information and comments on earlier drafts.

The Morocco Infrastructure Review was prepared by the World Bank under the supervision of Marie Françoise Marie-Nelly (Country director for the Maghreb) and Carmen Nonay (Practice Manager, Water). The final report was prepared by Rajesh Advani (Sr. Infrastructure Specialist), with support from Michel Wormser (Consultant). The team would like to thank Xavier Reille (IFC Country Manager), Jaafar Friaa and Gabriel Sensenbrenner (Program Leaders) for their guidance and support. The team is also grateful for comments received from peer reviewers Marianne Fay (Chief Economist), Clive Harris (Head, Private Sector), and Ashish Khanna (Program Leader). The analytical work was carried out by a team consisting of Daniel Camos Daurella (Sr. Infrastructure Economist), Dambudzo Muzenda (Water Supply and Sanitation Specialist), Antonio Eustache (Consultant) and Mohamad Mahgoub (Consultant).

The financial support of the Public-Private Infrastructure Advisory Facility (PPIAF) is gratefully acknowledged.

The team is grateful to the following people for their input in preparation of this report:

IBRD: Jean-Denis Pesme (Manager), Kevin Carey (Manager), Steven Schonberger (Manager), Yolanda Tayler (Manager), Olivier Le Ber (Manager), Erik Fernstrom (Manager), Renaud Seligmann (Manager), Afef Haddad (Country Program Coordinator), Arnaud Dornel (Lead Financial Sector Specialist), Ousmane Kolie (Senior Financial Management Specialist), Arthur Foch (Senior ICT Policy Specialist), Augustin Maria (Sr. Urban Specialist), Carlo Rossotto (Lead ICT Policy Specialist), Asma Khouni and Claudine Kader (Program Assistants), Nabil Samir (Transport Specialist), Manaf Touati (Energy Specialist), Moez Cherif (Lead Energy Specialist), Diep Nguyen Van Houtte (Lead Transport Specialist), Patrice Caporossi (Senior Infrastructure Finance Specialist), Xavier Muron (Senior Infrastructure Specialist), Abdoulaye Keita (Senior Procurement Specialist), and the following consultants: Patrick Blanchard, Aurélie Dussenne, Richard Schlirf, Tito Yepes, Afaf Mkami, Abdoul Barry, Jean-Louis Martin, Wang Xuanhe, Faska Khrouz, Hassan Benabderrazik, Maria Bahnini, Michel Bellier, and Tayeb Amegroud.

IFC: Isabel Marques De Sa (Chief Investment Officer), Aurelien Boyer (Senior Investment Officer), Julie Carles (Principal Investment Officer), and Malak Draz (Investment Officer)

Numerous other people from the World Bank specializing in the following global themes contributed to this report: Macroeconomics, Financial Competitiveness and Innovation, Governance, Water, Energy, Transport and Digital. 


\section{Contents}

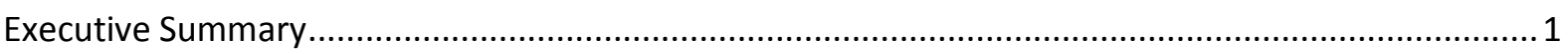

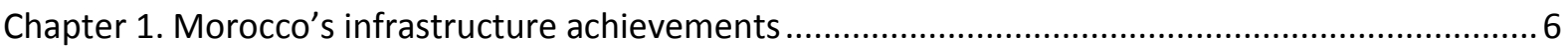

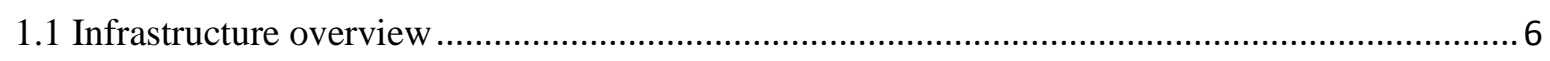

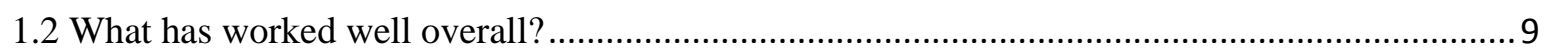

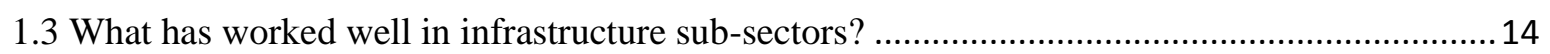

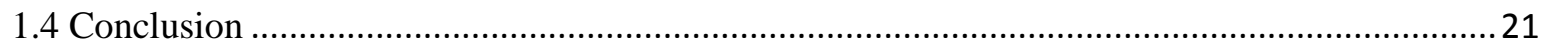

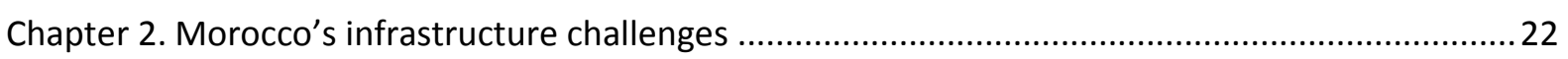

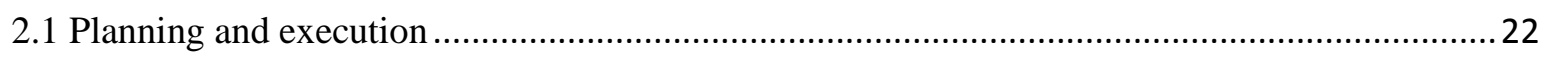

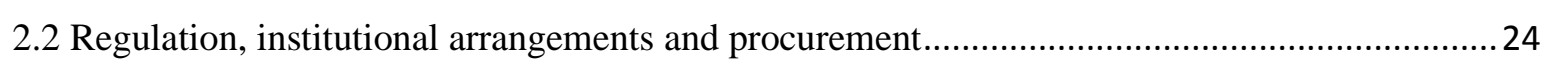

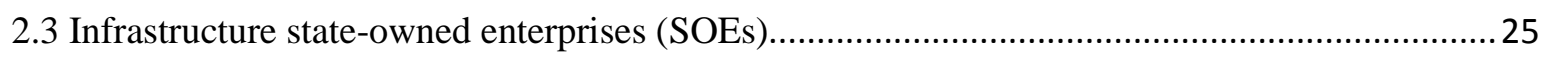

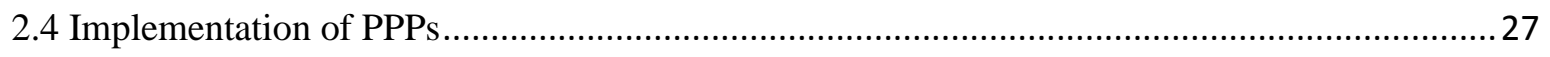

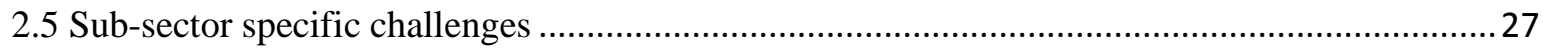

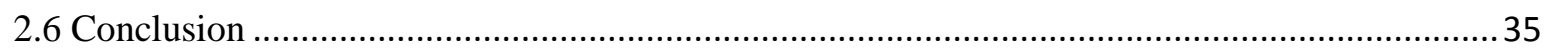

Chapter 3. Morocco's infrastructure investment \& spending needs ...................................................

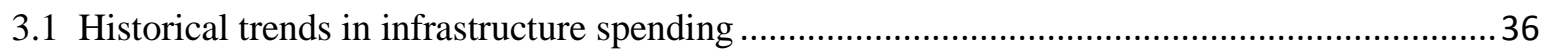

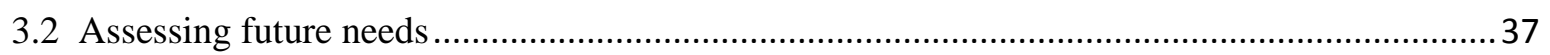

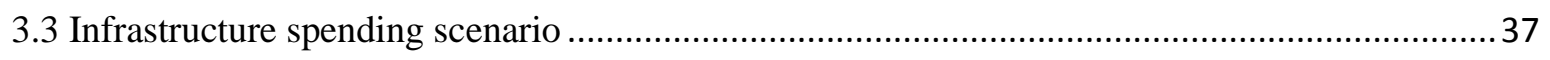

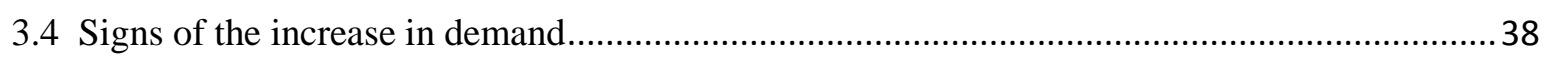

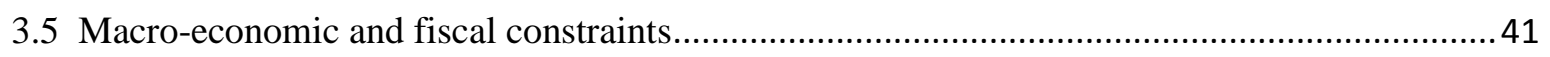

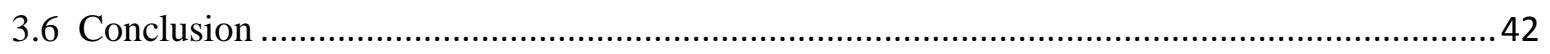

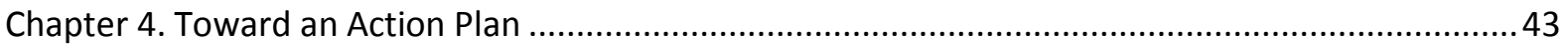

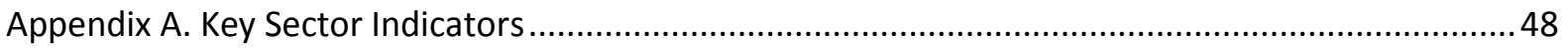

Appendix B. Sub-sector specific recommendations and investment project pipeline ......................... 54

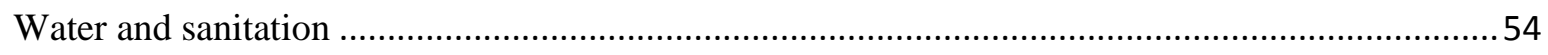

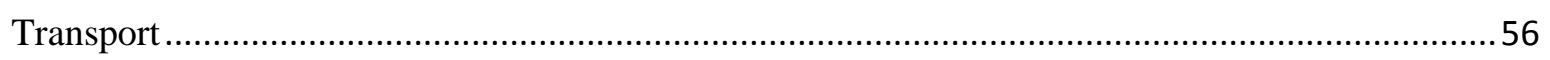

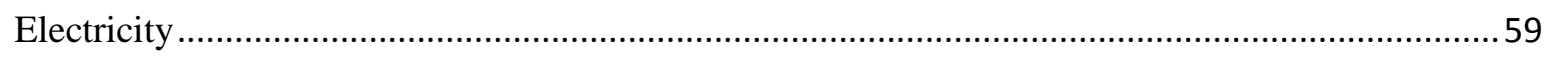

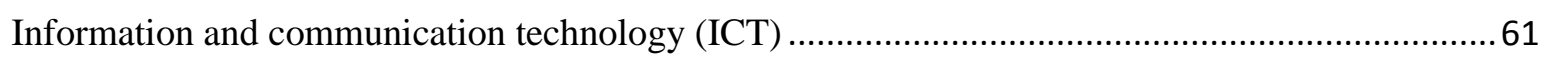

Appendix C. Methodology used to estimate infrastructure investment scenarios..............................64 


\section{Executive Summary}

Over the last twenty years, Morocco has invested massively in infrastructure. At the macroeconomic level, total investment of between 25 percent and 38 percent of gross domestic product (GDP) occurred between 2001 and 2017, one of the highest rates of investment globally. Much of this investment has gone into infrastructure, and more than half of it was undertaken by the public sector (treasury, public enterprises and local authorities). Morocco is also among countries receiving the most official development assistance relative to GDP, half of which is invested in infrastructure. The investments have created more reliable supply chains, improved access to markets and basic services, and increased productivity.

Investments in infrastructure have contributed to economic growth. Over the period 1985-2015, Morocco's economy has grown at an average rate of 4.3 percent per year, with infrastructure contributing about 1 percentage point to per capita GDP growth. Compared to other Maghreb countries, Morocco is doing better than Tunisia and Algeria on infrastructure growth payoffs, although it is still below the performance of Asian countries such as South Korea, Malaysia and China. The investments have also improved the country's competitiveness and its attractiveness to foreign investors.

Poverty has been considerably reduced. The quality of life has improved and obstacles that inhibit national development have reduced: poverty, unemployment, and regional imbalances. The percentage of the population living below the national poverty line of USD 2.15 per day fell from 15.3 percent in 2001 to 4.8 percent in 2014 . Urban poverty was virtually eradicated with only 1 percent of the urban population living in poverty, while poverty in rural areas declined by 16 percent, from 25 percent in 2001 to about 9 percent in 2014.

The investments have resulted in increased quality of and access to services. The quality of infrastructure services has improved with Morocco's global ranking moving from $64^{\text {th }}$ place in 2007 to $42^{\text {nd }}$ in 2017. Access to electricity is universal, as is access to drinking water in urban areas, and 89 percent of households have at least one basic sanitation service. Access to mobile telephony is good at 92 percent. Morocco has an extensive road network of $60,000 \mathrm{~km}$, one of the best railway networks in Africa, a world class port at Tanger Med, and a developed air transit network with 25 airports of which 19 are international.

The delivery of infrastructure services is predominantly through SOEs, most of which are covering operating costs through tariff revenues. Ten large SOEs provide infrastructure services: the Autoroutes du Maroc (ADM) for highways, the Agence Nationale des Ports (ANP), the Agence spéciale Tanger-Méditerranée (TMSA) and Marsa Maroc for ports, the Moroccan Agency for Sustainable Energy (MASEN) and the Office National de l'Electricité et de l'Eau Potable (ONEE) for electricity, water and sanitation, the Office National des Chemins de Fer (ONCF) for railways, the Office National des Aéroports (ONDA) for airports, Royal Air Maroc (RAM), the national airline, and Maroc Telecom ${ }^{1}$. In 2017, the combined annual operating revenue of these SOEs was MAD 107 billion (USD 11.1 billion), of which MAD 73 billion was for l'ONEE and Maroc Telecom, mainly from the sale of services to consumers. The combined self-financing capacity of 7 of the $\mathrm{SOEs}^{2}$ amounted to 12 billion Moroccan dirhams.

Morocco has experience with private sector participation and leveraging commercial finance for infrastructure. About 20 public private partnerships (PPPs) were undertaken between 1986 and 2017 across the infrastructure sectors and in agriculture. There have been notable successes, for example, in the operation of water supply in major cities, irrigation projects, ports and independent power production of electricity. Morocco has also been successful in raising commercial finance, with an estimated seventeen large-scale commercial infrastructure projects financed since 1997 at a cost of USD

\footnotetext{
${ }^{1}$ Maroc Telecom IS not technically an SOE due to its diverse shareholding; however, it is Morocco's largest telecom operator with 22 percent of its shares owned by the state

${ }^{2}$ In 2016 for SOEs for which data was available: AdM, ANP, MASEN, ONDA, ONEE, ONCF, TMSA
} 
12 billion, of which USD 9 billion was commercially financed. However, the vast majority of infrastructure projects have been undertaken by SOEs with financing from international development partners, which require state guarantees.

Morocco has made impressive progress in developing infrastructure but still faces challenges that have hindered the efficiency and impact of investments and increased its reliance on public resources and subsidies. Inadequate planning, uneven application of detailed investment plans, and inefficiencies in procurement have led to suboptimal choices, construction delays, and reduced outcomes. In some cases, these have contributed to higher unit costs for infrastructure development. Financial planning and the use of quantitative analysis to evaluate projects are insufficient given the high levels of investment in infrastructure. State subsidies and transfers to SOEs amount to MAD 29 billion (USD 3 billion) per annum, 20 percent of which is for infrastructure ${ }^{3}$.

The regulatory process lacks well-defined and transparent tools and processes. Regulatory functions are split across different entities, with some notable gaps. In an environment where regulation is mostly managed by contract, the lapses and non-systematic use of the contrats-programmes is a cause for concern. Also, the financial statements of SOEs are rarely disclosed. In some sectors, authorities use consultants to benchmark performance, however, the results are rarely made public. Tariff revisions are conducted by an inter-ministerial commission on prices without a public explanation of the rationale for tariff levels and structures. The recently established energy sector regulator is still not fully operational, and in water there are concerns over the fragmentation of roles and absence of a sectorwide regulatory framework.

A number of institutional weaknesses impact the efficiency and oversight of infrastructure SOEs. SOEs are responsible for a myriad of functions including infrastructure development, industrial development and poverty reduction, which sometimes overlap with other institutions. Despite having a core mandate in infrastructure, some SOEs engage in peripheral functions which has impacted their efficiency, burdening them with additional financial costs. The implementation of the Moroccan code of good corporate governance practices has been uneven and the boards of directors could be more effective. Typically, boards are comprised of representatives from key ministries. Some boards convene infrequently. The code encourages the introduction of independent board members expected to bring expertise, enrich debate and improve the quality of decisions. Since the summer of 2018, work has commenced on options for new economic models and restructuring certain SOEs that are experiencing significant constraints under the prevailing operational model.

The management of the contrats-programmes could be improved for SOEs subject to them. The contrat-programme is a key tool for managing the relationship between the state and SOEs, although some SOEs have other legislative tools and frameworks for supervision. They are not however applied evenly across all infrastructure agencies. For example, ONDA recently begun the preparation of its first contrat-programme to ensure alignment with government strategy. There are delays in the continuation of the contrat-programme, with several key agencies not having a valid one in place at this time. The contracts lack systematic incentives for performance - such as bonuses and sanctions - to encourage SOEs to meet their commitments. That said, actions to improve contract content and monitoring and evaluation have recently been undertaken. More emphasis on extracting and disseminating lessons from implementation, for example, by publishing reviews of contracts that have expired, could provide useful data to improve the contractual process.

At the end of 2017, the total debt (short and long term) of the ten-principle infrastructure SOEs amounted to nearly MAD 200 billion, which is equivalent to 19 percent of GDP. While it is prudent for market-based companies to have net fixed assets covered by a greater amount of equity and debt, a calculation of borrowing capacity for the main SOEs measured by debt relative to net cash flow reveals multiples of almost 10 for ADM, ONCF and $\mathrm{ONEE}^{4}$. These multiples are excessive, especially in cases

\footnotetext{
${ }^{3}$ State transfers to SOEs in 2017; sector allocation of $8 \%$ to transport, $8 \%$ to infrastructure and $4 \%$ to energy and mines (source: Report on SOEs for the 2019 budget year, Projet de Loi de Finances)

${ }^{4}$ For SOEs for which 2016-2017 figures are available
} 
where debt has been raised in foreign currency, whether directly or indirectly, as it further exposes the SOEs to exchange rate risk (albeit that the debt is partly concessional and benefits from long tenors).

Demand for infrastructure continues to grow across all sectors, putting pressure on existing assets. Due to population growth, urbanization, and improved per capita income levels, the growth in demand for infrastructure services has been quite rapid and is expected to continue to grow. Port traffic increased at an annual rate of 6 percent between 2000 and 2010, and in 2017 air traffic exceeded 20 million passengers for the first time. Electricity demand has increased at an average of 6 percent per annum since 2002, while the demand for drinking water has increased at 3.4 percent per annum. Climate change is having a negative impact on infrastructure, as seen in the damage to roads caused by floods and in water scarcity that has resulted in incidents of drought. This will call for more investment in wastewater reuse and desalination to build resilience to climate change.

The level of public debt will increasingly constrain government's ability to finance infrastructure from public sources. The ratio of central government debt to GDP of 65 percent - above the 58 percent unweighted average for the MENA region - represents a potential source of concern that will tighten the fiscal space for funding new infrastructure. In addition to this debt, the government provides guarantees to SOEs equivalent to 14 percent of GDP.

Looking forward, it would be critical for Morocco to maintain the momentum of investments in infrastructure. Continued spending is essential for Morocco to achieve its ambitious growth targets at a time when it is addressing challenges such as climate change, urbanization, and the pursuit of improved access to and quality of services. Achieving this at a time of reduced fiscal space will call for accelerated reforms aimed at lowering costs and increasing the efficiency, planning and outcomes from infrastructure investments, while mobilizing the expertise and resources of the private sector.

Four major cross-cutting areas of action are proposed. These actions are not sequential and may be carried out in parallel.

i. Improving the strategy, planning and impact of infrastructure investments. As noted in a 2016 report of the Moroccan court of auditors (Cour des comptes), certain ministries need to improve the definition of their sectoral strategy. Reform of the public investment management framework, as envisaged by the Ministry of Economy and Finance (MEF), is an important lever in improving planning and impact. It has four components (institutional, combined procedural and legal framework, project bankability, and training and communications) to aid in the selection of projects for financing by the state. The framework is expected to help identify commercially viable projects and evaluate progress throughout the project lifecycle. It is also expected to assess the financial and economic costs and benefits of proposed projects, which will help improve planning and improve value for money in public expenditure.

ii. Enhancing cost recovery and improving the management of fiscal impact. Through the adoption of quantitative techniques for performance benchmarking and the development of a rigorous methodology for setting tariffs, Morocco could identify areas to improve operating efficiency and cost recovery from user fees, while lowering the burden on fiscal resources. From a social perspective, cost reflective tariffs can be structured to safeguard the interests of the poor and vulnerable; hence, ministries and operators should design tariff structures that are aligned with social and demand management priorities. They should also consider applying periodic tariff adjustment mechanisms to compensate for inflation and operating cost variations, especially for essential inputs such as fuel.

iii. Improving the efficiency of SOEs. Increased efficiency could be achieved by rationalizing the mandates and responsibilities of public stakeholders across subsectors, applying the Moroccan code of corporate governance, increasing efficiency in the delivery of services, and strengthening the capacity to carry out new investments, including through more reliable use of the contratsprogrammes. These measures will eventually enable the SOEs to attract commercial investment 
on the strength of their own balance sheets. Partial equity listings of financially viable SOEs without full privatization - could help improve corporate governance, transparency, and the efficiency of public enterprises, while raising additional capital.

iv. Leveraging PPPs and mobilizing finance without state guarantees. Mobilizing private sector expertise and resources through PPPs can help improve the efficiency of infrastructure services and leverage government resources. In certain subsectors, user fees are sufficient to cover project costs and generate profits to attract private investors, whereas in other subsectors, the profitability and bankability of projects depends on state budget support. Channeling such support through a viability gap fund could make non-viable projects attractive to investors, especially where socioeconomic returns are high, while a project development fund could help prepare a robust pipeline for private sector participation. Strong technical capacity to originate, structure and monitor PPPs at national, regional and implementing agency levels is also essential to ensure effective management of the PPP process. Furthermore, while several SOEs have borrowed with the support of government guarantees, enabling them to borrow with less government support will help free fiscal resources. Morocco's financial system could further support domestic long-term borrowing, reducing overall foreign currency risk and diversifying financing sources while providing investment opportunities for local investors.

In addition to the cross-cutting actions outlined above, there are several measures to be taken at the infrastructure sub-sector level. The highlights of these are:

a. Water and sanitation: The proposed areas of reform consist of updating the institutional and regulatory framework, strengthening the viability of the agencies, and improving the management of water resources and reuse of wastewater. Envisaged measures: improving sector data and planning; establishing a water information system to collect, process and disseminate sectoral data through a national observatory; developing guidelines to implement the 2016 water law and facilitate the development of desalination, water recovery and reuse, while strengthening integrated water resources management; establishing performance and investment objectives in the contrat-programme between the state and ONEE; investing in rural water and sanitation to bridge access gaps; addressing financial sustainability by reviewing tariffs and other sources of finance (e.g. taxes and transfers) along the entire water chain; and, reconsidering the roles and functions of the agencies for regional agricultural development.

b. Transport: The proposed areas of reform are strengthening the regulatory framework, particularly with regards to the participation of the private sector, and improving the viability of public enterprises in the transport sector. Envisaged measures: increasing the operational efficiency of ONCF and considering opening parts of its operations to private sector participation; reviewing options for increased private sector participation in the ports and airports sub-sectors; continuing to improve the financial viability of AdM and ONCF, and the financial sustainability of the urban transport subsector through a review of tariffs and cost structures; and, sustaining the financial viability of the ports authorities (ANP, TMSA, and SODEP Marsa Maroc), and that of ONDA.

c. Electricity: The proposed areas of reform consist of liberalizing the renewable energy subsector, operationalizing energy efficiency measures, and pursuing the evolution of the institutional sector framework. Proposed measures: Operationalizing the independent regulatory authority, the Autorité Nationale de Régulation de l'Eléctricité (ANRE), to stimulate investment in renewables and regulate private energy companies; improving coordination within the sector by rationalizing the roles of sector agencies to clarify responsibilities, in line with the laws governing energy SOEs of 2016 (for renewables, law 13-09 is being revisited on its implications for public and private stakeholders); pursuing reforms to stimulate private investment in the small and medium size renewable energy market; and, operationalizing the law on energy efficiency to realize energy savings. 
d. ICT: Proposed measures: Strengthening the national policy framework to stimulate investment, including formal adoption of the national digital economy strategy and the sector orientation note for the period 2019-2024; stimulating competition by allowing new private sector entrants to invest in broadband infrastructure in Morocco; strategically utilizing the Universal Service Fund to attract private investment in broadband infrastructure in underserved areas; optimizing the use of existing digital infrastructures owned by SOEs; and stimulating the demand for broadband to boost domestic productivity by improving consumer readiness and increasing the availability of relevant local content.

Following this executive summary, Chapter 1 reviews the quantity and quality of infrastructure services in Morocco and the notable achievements that the country has made in this regard; Chapter 2 discusses Morocco's infrastructure challenges; Chapter 3 describes Morocco's infrastructure investment needs and macroeconomic constraints; and, Chapter $\mathbf{4}$ discusses proposed cross-cutting reforms. Appendix A provides key indicators for each infrastructure sector, Appendix B provides sector specific recommendations and lists selected projects in the infrastructure pipeline, and Appendix C explains the methodology used to derive the infrastructure investment estimates. 


\section{Chapter 1. Morocco's infrastructure achievements}

This chapter gives an overview of the notable achievements that Morocco has made as a result of its considerable investment in infrastructure. It reviews the substantial progress accomplished and provides a more detailed discussion of what has worked well in each of the economic infrastructure sub-sectors. The sector challenges, investment needs and macro-economic environment are subsequently discussed in chapters 2 and 3 .

\subsection{Infrastructure overview}

Morocco has achieved impressive progress in its infrastructure stocks. Over the past two decades, the country has invested heavily in all economic infrastructure sectors - transport (roads, rail lines, airports, and ports), water (including sanitation and irrigation), information and communication technology (ICT), and electricity - enabling a large proportion of its population to gain access to basic services. In recent years, Morocco has devoted considerable state resources towards infrastructure. Spending by the principal state-owned enterprises (SOEs) for transport, water and sanitation, irrigation, information and communication, and electricity has averaged 11.2 percent of gross domestic product (GDP). At the macroeconomic level, total investment of between 25 percent and 38 percent of GDP occurred between 2001 and 2017, one of the highest rates of investment globally. As a result of these supply-side measures, access rates are quite high nationally, although there are some gaps between rural and urban areas in water supply, sanitation, and ICT. Appendix A provides a list of access and performance indicators by sector.

Table 1.1 Access to Infrastructure in Morocco, National Level, 2005 and 2017

\begin{tabular}{|c|c|c|}
\hline & 2005 & 2017 \\
\hline Access to electricity (\% of population) & 80.3 & 100 \\
\hline People using at least basic drinking water services (\% of population) & 70 & $87^{\mathrm{a}}$ \\
\hline People using at least basic sanitation services (\% of population) & 73 & 89 \\
\hline Rail lines (total route-kilometers) & 1,907 & 2,109 \\
\hline Air transport, passengers carried & $3,492,984$ & $8,436,970^{b}$ \\
\hline Individuals using the Internet (\% of population) & 15 & 58 \\
\hline Mobile cellular subscriptions (per 100 people) & 41 & 121 \\
\hline
\end{tabular}

Source: World Development Indicators, 2017 \& WHO and UNICEF Joint Monitoring Program for water and sanitation Note a: Per ONEE, national access to basic drinking water service was 97 percent in 2017

Note b: Air passengers carried include domestic and international flights of authorized air carriers according to statistics from the International Civil Aviation Organization (ICAO) and estimates by ICAO staff. ONDA uses a different methodology and cites the number of air passengers carried at 9,192,770 in 2005 and 20,406,160 in 2017.

The stock and quality of infrastructure compares favorably to that of low- and upper- middleincome countries. For instance, Morocco has 139 large dams (with a total capacity of about 18 billion cubic meters ${ }^{5}\left[\mathrm{~m}^{3}\right]$ ) and around a hundred smaller dams and reservoirs. This represents a higher level of dam capacity per capita than the global median, and higher than that of other countries in the Middle East and North Africa (MENA), except for Egypt and Iraq (World Bank 2017). Morocco's renewable electricity output as a proportion of total electricity generation (17.2 percent in 2017) is much higher than other MENA countries such as Egypt (8 percent), Tunisia (3 percent), Jordan (1 percent), and Lebanon (3 percent). The rail network is 2,110 kilometers $(\mathrm{km})$ in total length, of which 75 percent is electrified and 28 percent double tracked. The railway network density - at $63 \mathrm{~km}$ per million inhabitants - is in line with that of other middle-income countries.

Access to basic infrastructure services is high. By 2018, 99.6 percent of Moroccan households had access to electricity thanks to the national rural electrification program, PERG, launched in 1996. According to the Office national de l'électricité et de l'eau potable (ONEE) and the Haut-Commissariat

${ }^{5}$ As of December 2017 
au Plan (higher planning commission), the rate of access to drinking water rose from 14 percent in 1994 to $85 \%$ in 2007 and to $96.6 \%$ by $2017^{6}$. This is largely the result of the drinking water supply program for rural populations (PAGER), which was launched by the government in 1997. Access to basic sanitation was 89 percent nationally, 94 percent in urban areas and 79 percent in rural areas in $2015^{7}$. In the ICT sector, access to mobile telephony is good with 92 percent access, but access to the internet is weaker at 62 (WDI 2017). In transport, Morocco has an impressive road network of $60,000 \mathrm{~km}$ and has created access in rural and mountainous areas, a network of motorways of over $1,800 \mathrm{~km}$ serving 60 percent of the population; developed airport infrastructure; one of the best rail networks in Africa including the first high speed rail link on the African continent; and a world class port at Tangier-Med.

The quality of Morocco's infrastructure has steadily improved over the last decade. Table 1.2 shows the change in the comparative global ranking of Morocco's infrastructure by sector in the ten years between 2007 and 2017. Morocco's ranking in international assessments of average infrastructure quality improved from 64th place to 42nd. Morocco is now considered to have better quality infrastructure than its Maghreb neighbors Algeria (ranked 97th) and Tunisia (ranked 86th). Morocco also outperforms its regional neighbors such as Lebanon (130th) and Egypt (73rd) but is well behind Gulf countries (such as Saudi Arabia, the United Arab Emirates, and Oman).

Table 1.2 Comparative ranking of Morocco's infrastructure, by sector, 2007 and 2017

\begin{tabular}{|c|c|c|}
\hline Category & $\begin{array}{c}\text { Rank among } \\
\text { 137 countries in 2017-18 }\end{array}$ & $\begin{array}{c}\text { Rank among 131 } \\
\text { countries 10 years earlier } \\
\mathbf{( 2 0 0 7 - 0 8 )}\end{array}$ \\
\hline Quality of overall infrastructure & 42 & 67 \\
\hline Quality of roads & 43 & 67 \\
\hline Quality of railroad infrastructure & 38 & 63 \\
\hline Quality of port infrastructure & 32 & 65 \\
\hline Quality of air transport infrastructure & 54 & 48 \\
\hline Available airline seat kilometers & 48 & 51 \\
\hline Quality of electricity supply & 46 & 103 \\
\hline Mobile-cellular telephone subscriptions per 100 \\
inhabitants
\end{tabular}

Source: Authors' elaboration based on the Global Competitiveness Reports by the World Economic Forum 2007-08; 2017-18

The investment in infrastructure has contributed to economic growth and poverty reduction. Over the period 1985-2015, Morocco has grown at an average rate of 4.3 percent per year ${ }^{9}$, during which the infrastructure sector added about 1 percentage point to per capita GDP growth. Compared to other Maghreb countries, Morocco is doing better than Tunisia and Algeria on infrastructure growth payoffs but is below the performance of Asian countries such as South Korea (1.7 percent), Malaysia (1.6 percent) and China $(2.7 \text { percent })^{10}$. The percentage of people living below the national poverty line of USD 2.15 a day fell from 15.3 percent in 2001 to 4.8 percent in 2014 . Urban poverty was virtually eradicated with only 1 percent of the urban population living in poverty, while poverty in rural areas declined by 16-percentage points from 25 percent in 2001 to about 9 percent in 2014.

\footnotetext{
${ }^{6}$ Sources: ONEE et Haut-Commissariat au Plan (HCP) (Objectifs du développement durable, https://odd.hcp.ma/ObjectifAssurer-un-environnement-durable_a144.html).

${ }^{7}$ UNICEF: Progress on household drinking water, sanitation and hygiene 2000-2017 (published 2019)

${ }^{8}$ The ranking is based on indicators developed for each country based on the answers provided by business leaders interviewed as part of a survey. For example, for the air transport, interviewees are asked to rate the air transport infrastructure in their country based on a scale from 1 (underdeveloped) to 7 (extensive and efficient by international standards). Individual answers are then aggregated to produce a score per country.

${ }^{9}$ Average GDP growth of Morocco over the period 1985-2015 calculated using WDI data.

${ }^{10}$ Based on a global model to calculate the impact of infrastructure development on economic growth over the past 30 years using indices to assess the contribution to per capita GDP growth change of the infrastructure sector as a whole, the infrastructure volume, and infrastructure quality
} 
The operation of infrastructure in Morocco is dominated by state-owned enterprises (SOEs). Out of 293 SOEs listed in the Ministry of Economy and Finance report on public enterprises, 23 are operating in infrastructure sectors. Most of these are in the commercial category, except the Agence Nationale des Ports (ANP), Caisse pour le Financement Routier (CFR), the Nador West Med port, and the tramway company (SRTS). CFR, Office National des Chemins de Fer (ONCF) - both rail, Office National des Aéroports (ONDA for airports), ONEE (electricity, water and sanitation), twelve municipal electricity/water distribution SOEs, and Régie autonome des frigorifiques de Casablanca (cold storage) are legally registered as "Etablissements Publics" to "droit public" (i.e., not to laws applicable to corporates) and are financially autonomous from the state. The remaining infrastructure SOEs are limited companies ("Sociétés Anonymes" - SA). Table 1.3 presents a list of infrastructure SOEs.

Table 1.3 - List of Infrastructure State-Owned Enterprises

\begin{tabular}{|c|c|c|c|}
\hline Sector & Sub-sector & $\begin{array}{l}\text { Number } \\
\text { of SOES }\end{array}$ & Names/Acronyms \\
\hline Energy & Power \& Gas & $\begin{array}{r}1 \\
1 \\
1 \\
11 \\
1\end{array}$ & $\begin{array}{l}\text { ONEE }^{11} \text { - Branche Electricité } \\
\text { MASEN (renewables) } \\
\text { MASEN }{ }^{12} \text { Capital (renewables) } \\
\text { RADEE (régies autonomes de distribution } \\
\text { d'eau et d'électricité) }^{13} \\
\text { RADEEM (Marrakech) }\end{array}$ \\
\hline \multirow[t]{7}{*}{ Transport } & Ports & $\begin{array}{l}1 \\
1 \\
1 \\
1\end{array}$ & $\begin{array}{l}\text { ANP (Agence Nationale des Ports) } \\
\text { TMSA (and in particular its subsidiaries } \\
\text { TMPA and TM2) in Tangiers } \\
\text { NADOR WEST MED } \\
\text { MARSA MAROC (ex SODEP) for other ports }\end{array}$ \\
\hline & Airline & 1 & RAM (Royal Air Maroc) \\
\hline & Airports & 1 & ONDA (Office National des Aéroports) \\
\hline & Rail & 1 & ONCF (Office National des Chemins de Fer) \\
\hline & Highways & $\begin{array}{l}1 \\
1\end{array}$ & $\begin{array}{l}\text { ADM (Société Nationale des Autoroutes Du } \\
\text { Maroc) } \\
\text { CFR (Caisse pour le Financement Routier) }\end{array}$ \\
\hline & Buses \& Trams & $\begin{array}{l}1 \\
1 \\
1\end{array}$ & $\begin{array}{l}\text { CASA TRANSPORTS (in Casablanca) } \\
\text { RATS (Régie Autonome des Transports } \\
\text { Urbains de Safi) } \\
\text { SRTS (Société du Tramway Rabat-Salé) }\end{array}$ \\
\hline & Logistics & $\begin{array}{l}1 \\
1\end{array}$ & $\begin{array}{l}\text { SNTL } \\
\text { RAFC (cold storage in Casablanca) }\end{array}$ \\
\hline $\begin{array}{l}\text { Water \& } \\
\text { Sanitation }\end{array}$ & $\begin{array}{l}\text { Water \& } \\
\text { Sanitation }\end{array}$ & $\begin{array}{r}1 \\
11\end{array}$ & $\begin{array}{l}\text { ONEE - Branche Eau } \\
\text { RADEE (régies autonomes de distribution } \\
\text { d'eau et d'électricité) regional }\end{array}$ \\
\hline Total & & 27 & \\
\hline
\end{tabular}

\footnotetext{
11 ONE (power) and ONEP (water and sanitation) merged in 2012 and are counted as a single SOE in this table.

12 MASEN and MASEN Capital are also counted as a single SOE in this table.

13 The various regional-municipal public utilities, active in both power and water distribution, have been regrouped under the acronym RADEE in this table.
} 


\subsection{What has worked well overall?}

The delivery of infrastructure services is predominantly through state-owned enterprises (SOEs), most of which are covering operating costs from tariff revenues. Ten large SOEs provide infrastructure services: the Autoroutes du Maroc (ADM) for highways, the Agence Nationale des Ports (ANP), the Agence spéciale Tanger-Méditerranée (TMSA) and Marsa Maroc for ports, the Moroccan Agency for Sustainable Energy (MASEN) and the Office National de l'Electricité et de l'Eau Potable (ONEE) for electricity, water and sanitation, the Office National des Chemins de Fer (ONCF) for railways, the Office National des Aéroports (ONDA) for airports, Royal Air Maroc (RAM), the national airline, and Maroc Telecom ${ }^{14}$. In 2017, the combined annual operating revenue of these SOEs was MAD 107 billion (USD 11.1 billion), of which MAD 73 billion was for l'ONEE and Maroc Telecom. The majority of revenues were from the sale of services to consumers. The combined surplus operating cash flow of seven of these SOEs was MAD 12 billion (USD 1.3 billion) ${ }^{15}$.

Morocco performs quite well on indicators of governance, as determined by the World Governance Indicators. It compares favorably to its peers among lower-middle-income countries on measures of government effectiveness, regulatory quality, rule of law, and control of corruption-all indicators to which investors are attentive. Morocco's legal and regulatory framework for public procurement has improved in the past few years. Procurement processes for major infrastructure financed by the state or by SOEs are governed by Decree 2-12-349 of March 20, 2013. The current legal framework for public procurement is well balanced - reflecting principles of economy, equality, transparency and integrityand for the most part reflects international best practices. Furthermore, SOEs receiving state financial support are subject to procurement regulations and management controls in accordance with article 18 of law $n{ }^{\circ}$ 69-00 of November 11, 2003. Morocco is one of two countries in the region (the other being Egypt) with a code of good corporate governance practices, which applies to both public and private enterprises. Launched in 2008 with an annex on SOEs added in 2012, it addresses issues such as company strategic orientation, budgeting, activities and objectives, recruitment of managers, financial disclosure and compliance with accounting principles. It also covers board appointments, responsibilities of board members, and treatment of shareholders and stakeholders. Its adoption and application on a "comply or explain" basis is consistent with international best practice (OECD, 2012). Morocco is also relatively more transparent in disclosing information on SOEs than its neighbors. The Department of Public Enterprises and Privatization (DEPP) provides consolidated statistics on SOE performance, state support to SOEs and indicative future restructuring plans. Similarly, the Court of Auditors issues reports on SOE performance. On the financing side, Morocco has gradually adopted the legal and regulatory framework needed to mobilize long-term savings towards diversified long-term investments without bank intermediation through mutual funds, and securitized assets and bonds. As has been done in countries such as Malaysia, Chile, and Peru, there is potential to channel more savings towards financing or refinancing core infrastructure.

Morocco has made significant progress in strengthening its public procurement system over the past fifteen years. A government decree reformed the central procurement board into a new policy, complaints handling, and capacity building body, the Commission Nationale de la Commande Publique $(\mathrm{CNCP})$. The $\mathrm{CNCP}$ is an independent and autonomous entity, and its mandate includes overseeing public procurement, controlling public spending, ensuring transparency and parity in the development and execution of contracts between competitors, and improving complaints handling. In January 2018, the government installed the twelve members of the CNCP to make it operational.

Morocco has had significant experience with various forms of private sector participation in the development and operation of infrastructure. This analysis identified twenty public private

\footnotetext{
${ }^{14}$ The list also includes Maroc Telecom, which is not technically an SOEs due to its diverse shareholding. Nevertheless, it is Morocco's largest telecom operator with 22 percent of its shares owned by the state

${ }^{15}$ For the following SOEs for 2016 for which data was available: AdM, ANP, MASEN, ONDA, ONEE, ONCF, TMSA
} 
partnerships ${ }^{16}$ (PPPs) that were undertaken between 1986 and 2017, almost all of them as concessions or involving the delegation of services in commercial sectors including electricity, water, irrigation and ports. These PPPs were negotiated on a case-by-case basis by local public authorities or by the state, and many were concluded before the adoption of Law 54-05 of February 14, 2006 for the delegated management of public services. Notable successes have been recorded in the water sector in three major cities: Casablanca (with Lyonnaise des Eaux, now Suez, in 1997, for a 30-year concession); Rabat (with Redal in 1998 for a 30-year concession); and, Tangiers (with Amendis, in 2002, for a 25-year concession) (ACWUA, 2014). In Casablanca, water supply coverage in the concession area went up from 71 percent to 93 percent in the first eight years. In Tangier and Tetouan (together serving about 1.1 million people), water coverage rose from 67 percent to 76 percent and from 79 percent to 86 percent, respectively, between 2001 and 2005. There was a marked reduction in non-revenue water across the three cities, which decreased from 36 percent in 1997 to 20 percent in 2018. Another example of a successful PPP is that of the port of Tangier-Med. Morocco is one of a handful of countries to have successfully developed a PPP irrigation scheme at Guerdane. The government also recently signed a PPP contract to construct, operate, and maintain a desalination plant for irrigation and drinking water at Chtouka, a region near the coast that relies heavily on agriculture.

Successes have also been recorded in the energy sector, where the independent electricity producer model has been facilitated by ONEE. Several power plants were developed using take-orpay contracts. For example, the Jorf Lasfar coal fired power plant is one of the largest independent power facilities of its kind in Africa or the Middle East, the original contract for which was signed in 1997. At the end of 2018, 61.6 percent of electricity production came from private operators ${ }^{17}$. This proportion is expected to increase to 76 percent in 2019 and to 83 percent in 2023 (source ONEE).

There is significant experience with renewable energy PPPs. More recently, the PPP model implemented by MASEN has helped boost renewable energy development in Morocco. As a public limited company, MASEN has the mandate to coordinate and optimize the tendering process to select qualified bidders to develop and operate renewable energy projects. MASEN manages risk allocation to maximize the competitiveness of each project by taking on one or more of the following roles: purchase of electricity, land provision, lender, shareholder or developer and manager of common infrastructure sites. For its initial projects, and to reduce the cost of funding, MASEN has financed the investments largely using concessional debt backed by state guarantees. This model has enabled MASEN to attract international development partner finance, while benefitting from the reduced cost of renewable technologies. As the competitiveness of renewable technologies improves, the use of commercial financing will increase resulting in a more balanced financing mix of renewable energy projects. Africa's first green bond for MAD 1,150 million (USD 120 million) issued by Morocco illustrates the use of innovative financing, and has helped finance solar projects such as Noor Laayoune, Noor Boujdour and Noor Ouarzazate IV.

A relatively sound system is in place to manage the procurement and implementation of PPP contracts. PPP procurement is well defined and includes open procedure, restricted procedure, and competitive tendering with the possibility of multistage tendering. The members of the inter-ministerial commission on PPPs and their substitutes are appointed by order (arrêté) of the Minister of Economy and Finance. The public notice of a PPP is issued by the procuring authority and is made available online, allowing both Moroccan and foreign companies to submit their bids within 40 calendar days ${ }^{18}$. Transparency is maintained throughout the procurement process, with no restrictions on direct negotiation. Answers to clarifications on procurement notices and requests for proposals are to be publicly disclosed. There is no standstill period, negotiations with the selected bidder are not restricted,

\footnotetext{
16 Interpretation of PPP for the purposes of this paper: A long term contract between a public party and a private party for the development and management of a public asset, including potentially the management of a related public service, in which the private party bears significant risk and management responsibility throughout the life of the contract, provides a portion of the finance at its own risk, and remuneration is significantly linked to performance and/or the demand or use of the asset or service so as to align the interests of both parties.

${ }^{17}$ Either in the context of PPPs, Law 13-09 or self-production.

${ }^{18}$ Depending on the complexity of an operation, this period may be extended.
} 
and an excerpt from the contracts is disseminated and made accessible online. Foreign companies working in Morocco under PPP agreements are allowed to repatriate their income. Dispute resolution mechanisms exist, notably national arbitration, international arbitration and procedures to settle disputes between investors and the state. Lenders' step-in rights are expressly established in the regulatory framework, as are the grounds for and consequences of terminating PPP contracts.

Restrictive agreements and practices are regulated by law, making the business environment more conducive to private investment. Morocco's Competition Law No. 06-99 on free pricing and competition (June 2000) established the authority of the Competition Council as an independent executive body with investigative powers. Together with the Central Authority for the Prevention of Corruption, the council is one of the main actors in charge of improving public governance and advocating for further market liberalization. Law No. 20-13 of 2014 amended the powers of the Competition Council to bring them in line with the 2011 constitution, and it is now charged with: i) making decisions on anti-competition practices and controlling concentrations, with powers of investigation and sanction, ii) providing opinions during official consultations by government authorities, and iii) publishing reviews and studies on the state of competition ${ }^{19}$.

Morocco has exploited the mixed ownership model to help co-finance investment in infrastructure. While SOEs dominate the infrastructure space, Morocco has utilized sociétés anonymes and sociétés mixtes ownership structures, and joint ownership arrangements between the government and the private sector are common. In ICT, the state owns 30 percent of Itissalat Al Maghrib (also known as Maroc Telecom) while Etisalat holding has a 53 percent stake and the remaining 17 percent is held by public investors. Meditel (also known as Orange) has state participation through the Caisse de Dépot et de Gestion, which holds 25.5 percent, while Orange holds 49 percent and Financecom 25.5 percent. Sixty-nine percent of Wana Corporate (also known as Inwi), the third operator, is owned by $\mathrm{Al}$ Mada (a Moroccan private investment fund with pan-African investments) and the remaining 31 percent by Zain. In the transport sector, after over 40 years of state ownership, the Compagnie du Transport au Maroc (CTM) $)^{20}$ was fully privatized in 1993 and listed on the Casablanca stock exchange. The sale of CTM resulted in a radical improvement in the company's management, finances and services (L'Economiste, 1997). Similarly, Morocco's main port operator Societe d'Exploitation de Ports (SODEP) or Marsa Maroc, raised MAD 1.94 billion (USD 198 million) through its initial public offering in 2009, of which 30 percent came from individual investors. The energy sector also has mixed ownership, as in the case of MASEN and ONEE, while some independent power producers (IPPs) are privately owned.

Morocco has also recorded successes in raising commercial financing. This analysis has identified seventeen large-scale commercial infrastructure projects financed since 1997 at a cost of USD 12 billion. The list includes economic infrastructure projects (electricity generation, ports, and water) without taking into consideration telecommunications networks, which are financed on a corporate basis by the three major mobile and fixed network operators. The total cost of 17 major projects was approximately USD 12.2 billion (in current dollars) over the period 1997-2017, with commercial financing accounting for approximately USD 9 billion, including financing from export credit agencies (refer to Table 1.4 and Box 1 with definitions of commercial financing).

Table 1.4 Large Commercial Infrastructure Projects Financed in Morocco ${ }^{21}$, 1997-2017

\begin{tabular}{|l|c|c|c|c|}
\hline Name & Sector & $\begin{array}{c}\text { Year of financial } \\
\text { close }\end{array}$ & $\begin{array}{c}\text { Project cost } \\
\text { (MUSD) }\end{array}$ & Type of financing \\
\hline Jorf Lasfar 1 & Energy, Coal & 1997 & 1,483 & Project Finance \\
\hline Al Koudia & Energy, Wind & 1999 & 60 & Project Finance \\
\hline
\end{tabular}

\footnotetext{
${ }^{19}$ Source: https://www.export.gov/apex/article2?id=Morocco-Legal-Regime

20 CTM offers passenger, freight and transportation services, mainly through coach buses, and serves 130 destinations domestically and abroad.

${ }^{21}$ Excluding private projects developed within the framework of law 13-09 i.e. the Akhfennir 1 and 2 wind projects (200 MW); Foum Al Oued (50 MW); Cimar (5 MW); Haouma (50 MW); Lafarge (50 MW); Aftissat (200 MW); Jbal Khalladi (120 MW).
} 


\begin{tabular}{|c|c|c|c|c|}
\hline Tahaddart & Energy, gas & 2003 & 329 & Project Finance \\
\hline Guerdane & Water & 2005 & 86 & Public Finance \\
\hline TC1 Tanger Med 1 & Transport, Port & 2005 & 170 & Corporate Finance $^{1}$ \\
\hline TC2 Tanger Med 1 & Transport, Port & 2008 & 150 & Project Finance \\
\hline Tarfaya & Energy, Wind & 2012 & 564 & Project Finance \\
\hline Jorf Lasfar 2 & Energy, Coal & 2013 & 1,813 & Project Finance \\
\hline Noor Ourzazate I (CSP) & Energy, Solar & 2013 & 1,000 & Structured Public Finance $^{2}$ \\
\hline Safi & Energy, Coal & 2014 & 2,590 & Project Finance \\
\hline Khalladi & Energy, Wind & 2015 & 180 & Project Finance \\
\hline Noor II \& III CSP & Energy, Solar & 2015 & 2,000 & Structured Public Finance $^{2}$ \\
\hline Noor Ouarzazate IV PV & Energy, Solar & 2017 & 78 & Structured Public Finance $^{2}$ \\
\hline $\begin{array}{l}\text { Noor Laayoune I/Noor } \\
\text { Boujdour I }\end{array}$ & Energy, Solar & 2017 & 130 & Structured Public Finance ${ }^{4}$ \\
\hline TC3 Tanger Med 2 & Transport, Port & 2015 & 280 & Corporate Finance $^{1}$ \\
\hline TC4 Tanger Med 2 & Transport, Port & 2016 & 900 & Corporate Finance $^{1}$ \\
\hline Agadir - Chtouka & Water & 2017 & 400 & Project Finance $^{3}$ \\
\hline Total & & & 12,213 & \\
\hline
\end{tabular}

\section{Box 1.1: Explaining Commercial Financing}

In the context of the discussion on infrastructure financing in this paper, the term "commercial finance" refers to finance that has any of the following characteristics:

i. the borrower is "commercial", which includes profit oriented SOEs as well as private sector projects or utilities.

ii. the lender is "commercial", referring to profit-oriented banks or financial investors.

iii. the terms of the transactions are consistent with arm's length market practices of commercial lenders

iv. the financings are ultimately repaid from cashflows or sources of funds that do not rely on government budget and taxpayer contributions.

The main types of commercial financing are: project finance (project cost USD 1 billion per annum during 2012-2017) and corporate finance (project cost USD 240 million per annum not including the ICT sector and mainly through shareholder equity and loans). Additionally, in recent years Morocco has actively resorted to structured public finance (ODA loans made directly to SOEs and guaranteed by the state). The volume of infrastructure projects financed on a structured public finance ${ }^{22}$ basis (mostly through MASEN) has averaged around USD 640 million annually during 2013-2017. The electricity sector accounts for 82 percent of project finance (Figure 1.1 shows the commercially financed infrastructure transactions and Table 1.5 shows the disaggregation by sector). A comparison of Morocco and 12 peers in size, per capita income, and sovereign rating, shows that Morocco is well within the norm for mobilizing project finance in infrastructure. Morocco's sovereign credit is currently rated at (or near) investment grade, with a Standard \& Poor's and Fitch ratings of BBB- and a Moody's rating of Ba1.

22 "Structured public finance" refers to external loans from development agencies made directly to SOEs for which the responsibility for repayment rests with the SOEs. 
Figure 1.1 Commercial Financing for Infrastructure in Morocco, 1995-2015

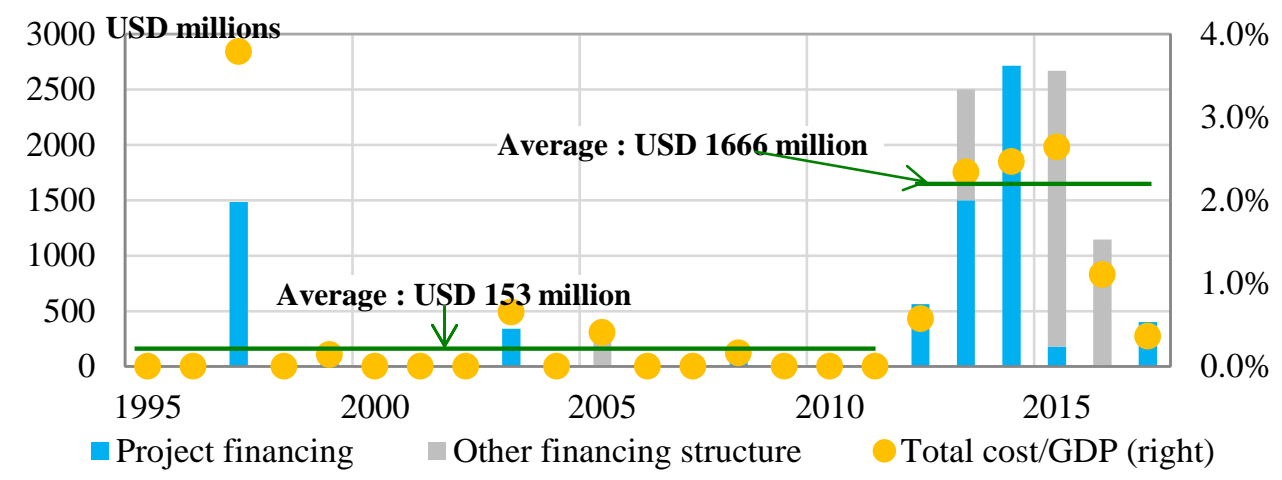

Source: Project Finance International and authors' calculations.

Table 1.5 Commercial Financing of Large Infrastructure Projects in Morocco since 1997, by Sector

\begin{tabular}{|lccc|}
\hline \multicolumn{1}{|c}{ Sector } & Number of & \multicolumn{2}{c|}{ Project cost } \\
\cline { 3 - 4 } & transactions & USD billion & \% \\
\hline Thermal power stations (coal or gas) & 4 & 6,215 & $51 \%$ \\
Wind or solar farms & 7 & 4,014 & $33 \%$ \\
Port terminals & 4 & 1500 & $12 \%$ \\
Water (desalination and irrigation) & 2 & 486 & $4 \%$ \\
\hline Total & 17 & 12,215 & $100 \%$ \\
\hline
\end{tabular}

Source: International finance publications and team's estimates

Sources of funds for these large-scale commercial infrastructure projects between 2013 and 2017 include: 30 percent from shareholders (equity and loans), 29 percent from state agencies (notably onlending through MASEN), 19 percent from international sources and export credits (guaranteed), 14 percent from domestic banks, and 6 percent unguaranteed loans from international banks. New loans from domestic banks averaged USD 250 million annually.

Morocco is also among countries receiving the most official development assistance (ODA) relative to its GDP, half of which has been invested in infrastructure. According to estimates of the Organisation for Economic Co-operation and Development (OECD), over the period 2012-16, annual ODA flows into Morocco were about USD 2.4 billion (2.3 percent of 2016 GDP) in disbursements and USD 2.7 billion in new commitments. On average, just over half of this amount, USD 1.3 billion (1.2 percent of 2016 GDP), was for infrastructure (Table 1.6). In 2016, among peer countries in the MENA, South Asia, and Southeast Asia, only Jordan received greater ODA flows as a proportion of GDP (Figure 1.2). Comparing ODA flows per capita leads to the same conclusion: Morocco receives, as a proportion of its GDP and its population, higher ODA flows, particularly for financing infrastructure, than almost all of its peers. The ODA has strengthened the infrastructure providers, which has helped attract commercial financing and partnerships with the private sector. For example, ODA investments in MASEN and ONEE have improved their financial sustainability, allowing them to enter into financing and power purchase agreements with private enterprises.

Table 1.6 ODA Received by Morocco (Disbursements in USD billion)

\begin{tabular}{|l|c|c|c|c|c|c|}
\hline & $\mathbf{2 0 1 2}$ & $\mathbf{2 0 1 3}$ & $\mathbf{2 0 1 4}$ & $\mathbf{2 0 1 5}$ & $\mathbf{2 0 1 6}$ & $\begin{array}{c}\text { average } \\
\mathbf{2 0 1 2}-\mathbf{1 6}\end{array}$ \\
\hline Total ODA received & 2.0 & 2.6 & 2.8 & 2.0 & 2.7 & 2.4 \\
\hline ODA/GDP (\%) & $2.1 \%$ & $2.4 \%$ & $2.5 \%$ & $2.0 \%$ & $2.6 \%$ & $2.3 \%$ \\
\hline ODA/capita & 61 & 76 & 81 & 58 & 76 & 70 \\
\hline $\begin{array}{l}\text { Including: ODA for } \\
\text { infrastructure }\end{array}$ & 871 & 1,141 & 1,521 & 1,140 & 1,725 & 1,280 \\
\hline
\end{tabular}

Source: OECD. 
Figure 1.2 ODA Received by Morocco and Select Peers for Infrastructure, 2016

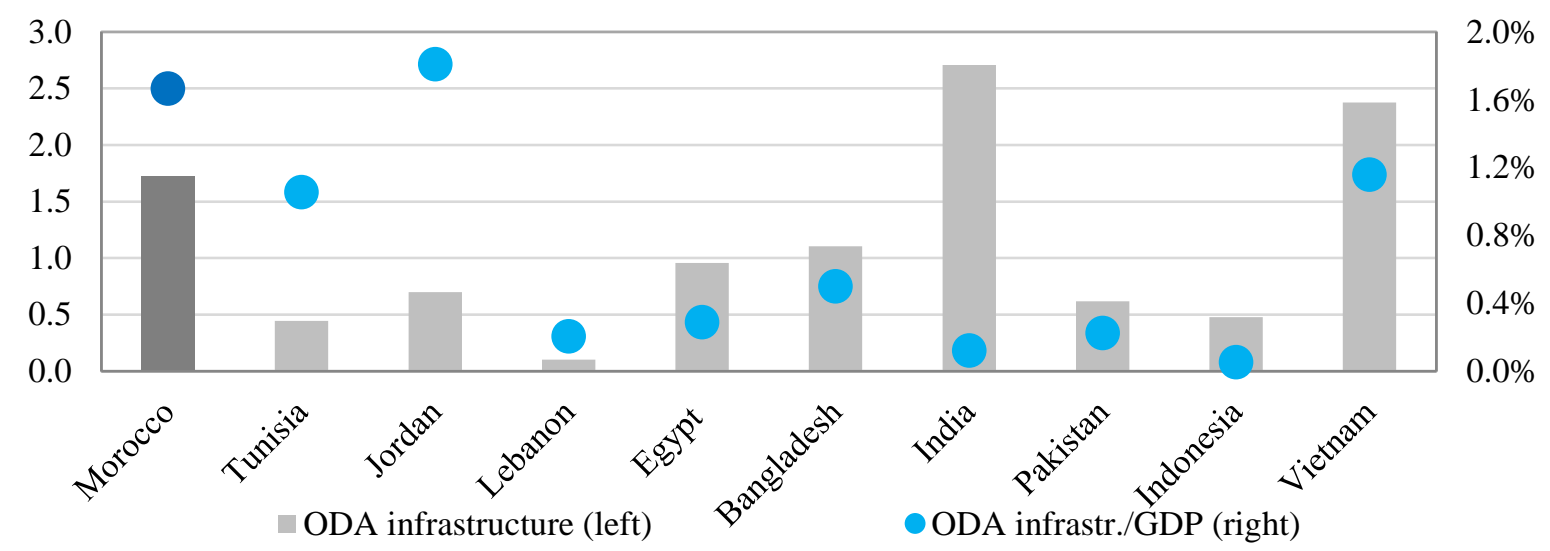

Source: OECD.

Reform of the public investment management framework initiated by the Department of Budget. This on-going reform aims to improve the selection of projects for state funding and to provide a system to evaluate progress throughout the project lifecycle. It is structured around four main components i) institutional: creation of a sub-department within the Department of Budget to monitor the public investment management (PIM) framework and of units within line ministries and SOEs to steer overall public investment; ii) unified legal and procedural framework: development of a legal framework to harmonize the rules for managing public investment projects supported by guides and practice manuals, including technical guidelines and methodologies for project evaluation; iii) project data bank: establishment of a database / information system on public investments to operationalize the PIM; and, iv) training and communication: implementation of a training plan to build stakeholder capacity to manage public investments and development of a communication plan to support implementation of the reforms and raise public awareness about the challenges and achievements of the program.

\subsection{What has worked well in infrastructure sub-sectors?}

This section looks at the successes that Morocco has achieved in the key infrastructure sub-sectors, and covers transport, energy, water and sanitation, and information communication and technology (ICT).

\section{Transport}

As Table 1.7 illustrates, Morocco outperforms the MENA regional average in terms of connectivity in three out of four transport sub-sectors - paved roads, ports and airports - and is almost at the benchmark level in railways.

Table 1.7 Country Comparison of Transport Subsector Performance in MENA

\begin{tabular}{|c|c|c|c|c|c|}
\hline & $\begin{array}{c}\text { Paved roads } \\
\%\end{array}$ & $\begin{array}{c}\text { Railways } \\
\%\end{array}$ & $\begin{array}{c}\text { Ports } \\
\%\end{array}$ & $\begin{array}{c}\text { Airports } \\
\%\end{array}$ & $\begin{array}{c}\text { Average } \\
\%\end{array}$ \\
\hline Egypt & 86 & 77 & 85 & 135 & 96 \\
\hline Jordan & 118 & 72 & 76 & 76 & 86 \\
\hline Morocco & 113 & 59 & 95 & 103 & 93 \\
\hline Tunisia & 108 & 166 & 45 & 126 & 111 \\
\hline MENA & 83 & 61 & 60 & 110 & 79 \\
\hline
\end{tabular}

Source: World Bank 2017.Note: MENA = Middle East and Africa. Methodology developed by the World Bank's Transport GP 23

\footnotetext{
${ }^{23}$ Numbers in the table are indicators on the quantity of infrastructure (based on connectivity). Road and rail connectivity are based on national connectivity. Their measures are based on normalized averages of lengths of paved roads or railways per $\mathrm{km}^{2}$ of land area, per capita and per USD of GDP. The method is explained in the following report: "Transport
} 
An assessment of what has worked well in each part of the transport sub-sector is presented below.

\section{a) Urban transport}

An effective approach has been taken to private sector participation in tramways in Rabat and Casablanca. Under management contracts for tramway operations in greater Rabat and greater Casablanca, operators receive a per-kilometer compensation from the conceding authority for the provision of specified services. The contracts, which contain financial incentives for reliability and quality, reduce commercial risk and could enable operators to access private financing in future, although the government chose to publicly finance these projects. According to a survey of tramway users $^{24}$, most were very satisfied or satisfied on issues of passenger welcome and information, punctuality and hours. Specifically, 54 percent were satisfied with the attitude and cordiality of tramway agents; 57 percent with information provided; 52 percent with the ticket price; 80 percent with the frequency; and, 80 percent with the reliability of information provided on board through audio and visual announcements.

\section{b) Ports}

World class ports. Tanger Med is a major international port hub and a gateway for Morocco's imports and exports. Tanger Med 1 was the first port to be developed as a public-private partnership (PPP) in 2007. The construction of Tanger Med 2 was completed in 2015, and it is expected to become operational in 2019. On its commissioning, the Port of Tangier will become the largest maritime transit hub in the Mediterranean Sea and on the African continent. The dry port of Casablanca, part of the 40 ha logistics platforms developed at Casablanca, Fes, Marrakech and Tanger, was the first of its kind in the country. ${ }^{25}$ It consists of an integrated customs dry ports and logistic zones connected to the rail network and was completed in 2008 at a cost of MAD 100 million (about USD 10 million).

The ports sector framework has enabled private sector financing following the implementation of relatively recent reforms. Law 15-02 of November 2005 launched a series of reforms in the ports sector, notably the creation of the national port agency (the Agence Nationale des Ports, ANP). The reforms clarified each entity's mandate and roles; liberalized the management, operation, and financing of ports; and introduced concessions and competition. Today, there is a clear institutional and regulatory framework: ANP is responsible for all of Morocco's ports, except Tanger Med, which is administered by the TMPA and Nador West Med currently under construction. The local port operator Société d'Exploitation des Ports, commercially operating as Marsa Maroc, manages and provides logistic services for terminals at nine ports across the country. The Tanger Med Special Agency (TMSA) owns the land and infrastructure and serves as the Tanger Med regulator.

\section{c) Airports}

Open Skies Agreement with the European Union. The airport sector has witnessed massive growth in demand in the past few years, spurred by the signing of the Open Skies Agreement with the European Union in 2006. To capitalize on this growing demand, several airport projects are planned in the following decade.

ONDA is in a generally sound financial health, with a strong capital base, an ability to cover its operating costs and to generate net profits (net profit in 2016 was MAD 485 million). ONDA's overall financial performance has been positive over the period 2011-16, in part due to the constant increase in

Infrastructure for MED11 Countries, CASE Network Report No. 108. 2012". Port and airport connectivity indicators are based on the Liner Shipping Connectivity Index (http://unctadstat.unctad.org/wds/TableViewer/tableView.aspx) and Air Connectivity Index (http://documents.worldbank.org/curated/en/859151468161649899/pdf/WPS5722.pdf), respectively.

24 Source: Les sixièmes journées internationales de réflexion en marketing Etude de satisfaction des usagers du Tramway Rabat-Salé

${ }^{25}$ Source : Un Premier Port Sec Sous Douane en Service, I'Economiste.com, http://www.leconomiste.com/article/un-premierport-sec-sous-douane-en-service, 1 August 2008 
air traffic at an annual average of 6 percent driven by more tourism and the large diaspora, and to the high collection rate of navigation charges at around 99 percent $^{26}$.

\section{d) Roads}

Morocco is ahead of its peers in paved road density. As of 2017, the total road network was 60,000 $\mathrm{km}$ long, of which 2,500 km (2 percent) was made up of highways (about 1,771 km) and expressways $\mathrm{s}^{27}$, $41,500 \mathrm{~km}$ (71 percent) was paved roads, and almost $16,000 \mathrm{~km}$ was unpaved roads (27 percent). Since 1990, the pace of road development has been constantly increasing and, today, Morocco boasts one of the most developed highway networks in Africa. Its road network also compares favorably to middleincome peers such as Peru, Serbia, Malaysia, and the Philippines (World Bank 2016).

The development of rural roads has had a positive impact on poverty. The government has prioritized rural road development as part of a strategy of reducing poverty, isolation, and social inequality across the country. Through successive programs - the first (1995-2005) and second (200616) national program for rural roads (Programme National de Routes Rurales, PNRR 1 and 2) and the Programme de Mise à Niveau Territorial (PMAT) —almost 25,000 km of rural roads were constructed or rehabilitated. Between 2000 and 2015, the paved road network in rural areas doubled to more than 60 percent mostly through paving previously unpaved secondary and tertiary roads. Thanks to the PNRR 1 and 2, almost 80 percent of the rural population now lives less than a kilometer from an allweather road, compared with only 34 percent in $1995^{28}$.

Autoroutes du Maroc (ADM) has generally respected its obligations under the last contrat programme. The contrat programme for 2008-15 included planned investment of MAD 31.7 billion, excluding VAT, which was successfully executed by ADM through MAD 37.2 billion of investment during this period, achieving most of its investment program (except $30 \mathrm{~km}$ of highways that were not finished). Investments have kept pace, reaching MAD 3.0 billion in 2016 and MAD 1.3 billion in 2017.

ADM has started to modernize its operations by subcontracting them to specialized companies. For instance, ADM has collaborated with Vinci, a French civil engineering company, to modernize and automate the toll system. While this is a relatively low-level contract, such cooperation with private companies is an encouraging sign that ADM is set to become more service oriented.

Dedicated funding mechanisms have created some stability in the sector. The first, the Fonds Spécial Routier, was established in 1989 and has an average budget of MAD 2 billion a year. The fund is financed by the fuel tax, vehicle registration tax, and a tax on axles prorated on weight. The second instrument is the Caisse de Financement Routier, which was established in 2005 and is financed by international financial institutions, toll revenues, and municipalities. These two mechanisms fund national and rural roads which are not commercially viable and cannot in general be developed as PPPs. They do not fund highways.

\section{e) Railways}

Morocco has one of the best railway networks in Africa. In the latest Global Competitiveness Index (2017-18), Morocco was ranked 38th out of 138 countries for the quality of its railroad infrastructure ${ }^{29}$ (WEF 2017). This puts Morocco ahead of all African countries and also of some of its middle-income peers such as the Philippines (91st) and Jordan (81st). Morocco is also the first country in Africa to build a high-speed rail line, the Ligne à Grande Vitesse Maroc (LGV), connecting Tangier and

\footnotetext{
${ }^{26}$ Source: ONDA

27 Highways are tolled whereas expressways are not. The level of services between the two also differs.

${ }^{28}$ This indicator only accounts for villages of more than 50 people

${ }^{29}$ Ranking by the World Economic Forum 2017-2018:

http://reports.weforum.org/global-competitiveness-index-2017-2018/countryeconomy-profiles/\#economy=MAR
} 
Casablanca over a $350 \mathrm{~km}$ route that passes through several cities. The line was completed and operationalized in late 2018 and is expected to spur economic and commercial activity - for instance, passenger travel time between Tangier and Casablanca went down from 4 hours 45 minutes to 90 minutes. The passenger line will also free-up the existing line to carry more freight to Tangier Med port. In urban areas, light rail systems are mainly operating in greater Rabat and Casablanca and are undergoing significant extension.

ONCF, as an experienced rail operator, has made substantial investments in both the quantity and quality of rail infrastructure over decades. ONCF was established as a state-owned public enterprise (établissement public à caractère industriel et commercial) in 1963 under the authority of the Ministry of Equipment, Transport, Logistics, and Water (METLE). It is the only provider of passenger rail services (except for light urban rail) and freight (except for private rail tracks). Its foundational legal framework is still in place, but a new law (52-03) of 2005, enabled the transformation of ONCF into a public limited company (Société Anonyme) - although this is still not effective. Furthermore, ONCF managed to meet its investment program as set out in its 2010-15 contrat programme.

\section{Energy}

Universal access to electricity. Thanks to the national rural electrification program, PERG, electricity access increased from 18 percent in 1995 to 99.6 percent in 2018. This program was financed through the participation of local communes, beneficiary households, and the national power utility, the Office National de l'Electricité et de l'Eau Potable (ONEE) at a cost of USD 2.5 billion $^{30}$. It has been so successful that the government plans to shut it down by 2022 (see Box 1.2).

Comparatively good quality of electricity supply. Although ONEE continues to experience network losses, it has significantly improved the duration of power cuts to 40 seconds (not counting exceptional incidents) in 2017, which is much lower than ONEE's own target of 1 minute, and a major improvement from the average duration of 23 minutes in 2008.

Morocco is on course to maximizing the use of domestic renewable energy resources. In 2009, Morocco adopted a national energy strategy aimed at reducing the country's import dependency, lowering energy intensity across the economy, managing demand and mitigating climate change. The renewable energy target was initially set at 42 percent of installed power generating capacity by 2020 , split equally between solar, wind and hydro. The target was adjusted to 52 percent by 2030 following the COP21 in Paris in 2015. Along with the United States, South Africa, India and China, Morocco represents a significant share of the concentrated solar power (CSP) market in the short- to mediumterm (World Bank, 2014) - a flexible technology that meets peak demand after sunset thanks to thermal storage. The country has more than 3,500 megawatts (MW) of renewable energy projects in operation today. The Noor Ouzarzate solar complex launched in 2010 had by the end of 2018 achieved an installed capacity of $580 \mathrm{MW}$. The Noor Laayoune I and Noor Boujdour I solar power plants, with a combined capacity of $105 \mathrm{MW}$ were also commissioned in 2018. Projects under development, Noor Tafilalt, Noor Midelt I and II, and Noor PV II, will all contribute to the 2030 targets. Morocco also has 1,200 MW of onshore wind projects in operation, including nearly $700 \mathrm{MW}$ developed by private companies under law 13-09. Another $850 \mathrm{MW}$ of wind projects on five sites are under development, and the existing Koudia Al Baida wind farm is being upgraded from 50 MW to $120 \mathrm{MW}$. Morocco has 1,770 MW of hydroelectric capacity from more than 20 dams $^{31}$ around the country, including the Afourer pumped storage power station of $460 \mathrm{MW}$. A similar station at Abdelmoumen is under development. All these projects contribute to the integration of renewable energies into the electricity network and the achievement of national goals through support from MASEN, ONEE and the private sector.

\footnotetext{
${ }^{30} \mathrm{~A}$ financing agreement has been signed with United Arab Emirates to provide individual photovoltaic kits to the households of the non-electrified communes covered by INDH

${ }^{31}$ Withdrawals from dams are prioritized for irrigation
} 
Box 1.2 PERG: Reducing urban-rural disparities in access to electricity

The nationwide deployment of Morocco's public utility-led national rural electrification program, PERG, began in 1996. Most of the progress occurred during the first decade, followed by a levelling out in the last 10 years or so. Initially, the target was to achieve 80 percent rural electrification by 2010, but the early success prompted an adjustment of the target to 98 percent by 2007, which was met in 2012. In terms of electricity infrastructure development, the total length of the low-voltage grid grew from 27,000 in 1996 to $164,000 \mathrm{~km}$ in 2012 (IEA 2014). Figure B 1.1 shows the change in access rates since the program's inception.

Figure B 1.1 Evolution of Morocco's rural electrification rate from 1995 to 2016

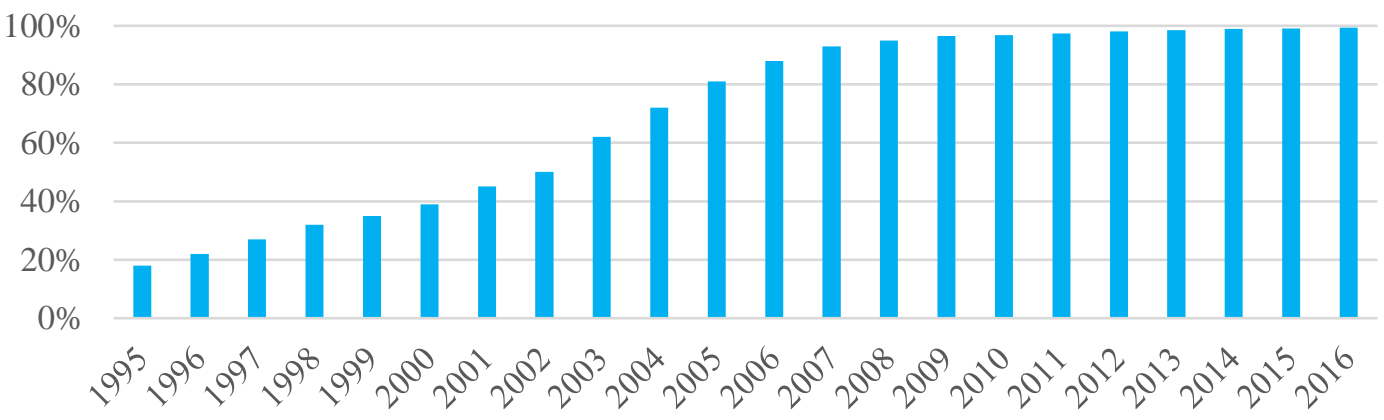

Compared with previous rural electrification programs in Morocco (the national program for rural electrification from 1982 to 1986, for example), the PERG utilized a more innovative financing model. It was financed through the participation of local communes, which met 20 percent of the connection costs, and beneficiary households, which met 25 percent of the connection costs (Islamic Development Bank, 2013), with the remaining 55 percent being borne by ONEE. The overall budget allocated to the program was MAD 24 billion of which 12.25 billion (51 percent) was sourced from donor institutions (Ministry of Energy 2017). Most of the connections were made directly to the grid, but basic, individual 75 watt peak (Wp) solar kits were also used for lighting and television and a $200 \mathrm{Wp}$ kit for refrigeration. A total of 51,559 solar kits were deployed by 2016. The PERG has had quantified and beneficial economic effects on the commercial, light industrial, and agricultural sectors.

Source: Ministère de l'Energie, des Mines et du Développement durable (MEMDD).

ONEE's contrat programme has helped strengthen its performance and stabilize the investment program. Under ONEE's 2014-2017 contrat programme, the company committed - among other things - to save MAD 8.2 billion (USD 870 million) through improved technical and commercial performance and cost reduction. It also developed the Safi thermal electricity plant, which will meet 25 percent of the national electricity demand in 2018. On the state's side, commitments included annual adjustments to the electricity, water and sanitation tariffs during the span of the contrat programme, and MAD 2 billion (USD 213 million) for the recapitalization of ONEE. The contrat programme has ended with 63 percent of the targeted electricity investments achieved. ONEE managed to save MAD 3 billion (USD 319 million) and its net profit evolved from a deficit to a net gain between 2013 and 2016.

Clear policy framework for energy efficiency. The National Energy Strategy (2009) set a goal of achieving 12 percent of energy savings by 2020 and 15 percent by 2030. This strategy was complemented by the 2011 Energy Efficiency Law (Law 47-09), which introduced appliance labeling, mandatory energy audits in industry, energy norms for new buildings, and mandatory impact studies for large energy projects. The Government of Morocco is focusing efforts to improve energy efficiency in all buildings and has issued a decree that allows for thermal regulations in residential buildings. Thermal building regulations apply to new residential and tertiary developments and support energy-efficient construction techniques for a new generation of environmentally friendly buildings. Measures have been developed and implemented for energy-efficient public street lighting and in public buildings and mosques.

\section{Water}


Morocco has invested in resource mobilization (dams, transfers), based on extensive planning by watershed. To mitigate the impacts of scarcity and interannual variability of freshwater supply, the country has developed dam storage capacity of 18.6 billion cubic meters capable of absorbing significant variations in precipitation (from 5 to 50 billion $\mathrm{m}^{3} / \mathrm{year}$ ). It has also set up inter-basin transfers to secure water resources for strategic consumption in Casablanca and Marrakech.

Virtually universal access to water supply and good access to sanitation. According to ONEE and the Haut-Commissariat au Plan, universal access to improved water sources in urban areas was generally achieved in 1995, while in rural areas the rate of access to drinking water rose from 14 percent in 1994 to 85 percent in 2007 and 96.6 percent by 2017 thanks to the rural drinking water supply program (PAGER) launched in 1997 (the national rate of access differs from the World Development Indicator of 87 percent on account of methodology). PAGER cost around USD 1.8 billion and was implemented by ONEE and local authorities. Eighty-three percent of the Moroccan population had access to basic sanitation in 2015 compared with 69 percent in 2000. In urban areas, 89 percent of the population had access to sanitation in 2015 compared with 87 percent in 2000.

On the whole, the state-owned utility ONEE is considered to be well-performing, and water distributors are deemed to be quite effective (ACWUA 2014). ONEE, the main institution responsible for water and sewerage service provision, is the largest infrastructure SOE by revenue and asset base. It owns bulk water assets and operates more than 80 percent of water supply in the country. It has embraced modern operating techniques. For instance, since 2000, ONEE has been using a systems, applications and products software, or SAP, which allows it to closely monitor the company's financial situation and implement management controls holistically across the major organizational functions. While most of its infrastructure investments have been financed through concessional loans, a share of commercial financing has been mobilized from local banks (at the end of 2017, local debt of the water department accounted for 31 percent; source: ONEE). In its 2014-2017 contrat programme, ONEE achieved 82 percent of its targeted investments in water.

Municipalities, which are responsible for water distribution, have taken a relatively proactive approach to integrating private capital. Municipalities use four models of water distribution and sanitation service provision: i) direct management; ii) autonomous agencies (in 12 cities); iii) delegation to ONEE (in around 600 small and medium towns); and, iv) delegation to the private sector by municipalities (concessions in the four large cities of Casablanca, Marrakech, Rabat and TangerTétouan). The municipal service providers have been cut off from most public financing since 2006, as a result of which they have generally financed themselves from commercial sources for major infrastructure investments with 5 to 15 -year loans at interest rates of 4 to 6 percent in local currency. Additionally, private water and energy concessionaires (such as Lydec) are listed on the Casablanca stock exchange and have been able to mobilize private capital through equity issues. This has increased the water sector's visibility with private financiers, both domestically and internationally.

The management of irrigation is decentralized and managed by regional authorities. Morocco has 1.46 million ha of permanently irrigated land, 682,600 ha of which are part of nine large-scale irrigation projects operated by nine public regional agricultural development offices (Offices regionaux de mise en valeur agricoles, ORMVAs). The ORMVAs are autonomous agencies with the mandate to develop agricultural land potential by: constructing new irrigation schemes, and rehabilitating and modernizing existing ones; ensuring irrigation and drainage facilities are operated and maintained; and, providing irrigation advisory services to farmers. The remaining area is shared between small- and medium-scale irrigation schemes managed by water users' associations (334,000 ha) and private irrigation schemes (441,000 ha).

Demand-side measures are in place to contain agricultural uses of water. In an effort to increase the productivity of water in agriculture, the Government of Morocco put in place a national plan for saving water in irrigation (Plan national d'économie de l'eau d'Irrigation, PNEEI). The PNEEI promotes more productive water use via efficient irrigation technologies (mainly drip irrigation) to be 
introduced over 555,000 hectares (ha) of irrigated land by 2020, of which 335,000 ha are in private farms and 220,000 ha are in large-scale irrigation areas. This process is supported by an agricultural development fund with up to 100 percent subsidy for the adoption of drip and microsprinkler irrigation and with 70 percent subsidy for sprinkler irrigation. Morocco's green plan (Plan Maroc vert) is expected to contain irrigation water demand growth from 12.04 billion $\mathrm{m}^{3}$ per year in 2010 to 12.4 billion $\mathrm{m}^{3}$ per year by 2030, mainly through water-saving measures. As the agriculture sector accounts for 80 percent of the country's water consumption, introducing water efficiency measures for agriculture is an effective way of making more water available for industrial and domestic use. An example of successful water demand management through the use of PPPs is shown in Box 1.3.

\section{Box 1.3 Irrigation PPPs: Risk Management a Key Success Factor}

Morocco is one of a few countries in the world with PPPs in irrigation, notably the Guerdane irrigation project. The project uses drip irrigation technology to grow high-value citrus fruit for export. The project managed demand risk by initiating a pre-subscription process before tendering, which helped ensure a sufficient base of end-users and signaled farmer willingness to pay to potential private partners. It also set the tariff below the marginal opportunity cost - if the farmer wanted to pump groundwater, he or she would pay more than purchasing it from the operator.

The source of water for irrigation is a dam, and the ability to transport the water reliably was crucial to the agricultural and commercial activities in the area and to the financial viability of the project. The state managed this risk through the following mechanism: if dam capacity fell below a certain threshold, the state would either compensate the operator or adjust the tariffs to mitigate financial loss to the operator. So far, the risk has not materialized and the state has not had to use the mechanism. However, the specificities of Guerdane as an area that grows high-value citrus fruit for export are not easy to replicate. The strong leadership by the Ministry of Agriculture in implementing this PPP was also a key success factor.

Source: Authors' elaboration.

\section{ICT}

Solid mobile connectivity performance. Morocco compares favorably to some of its peers in Africa and Asia on the Global System for Mobile Communications (GSM) connectivity index, which measures four key enablers of mobile internet adoption: i) quality of telecom infrastructure; ii) affordability of telecom services and devices; iii) consumers' readiness; and, iv) the relevance and availability of local content and services. Morocco's score of 58 (out of 100) is comparable to the scores of Egypt (56), Algeria (55.9), India (53.7), Kenya (51) and Pakistan (37.1). It performs particularly well on affordability (68) and content (66.5). The mobile phone market has now reached saturation (122 percent in 2016) as measured by the number of SIM cards relative to the population. The quality of connection and internet speed are also deemed good. According to the ANRT, 35 percent of the population does not yet have access to the internet, especially because of the high cost of service. Furthermore, while the connection quality and internet speed are considered among the best in Africa, they are largely lower than countries in central and eastern Europe (Akamai).

The private sector plays a leading role in the delivery of mobile services, with state financing through equity investments. The three largest operators of mobile services are: i) Itisalat Al Maghreb (44 percent market share), with the Emarati-based Etissalat as the majority shareholder with a 53 percent stake and the state with a 30 percent stake; ii) Medi Telecom-known as Meditel (33 percent market share), now operating as Orange which holds 49 percent of Meditel's capital; and, iii) Wana Corporate (23 percent market share) now branded as Inwi, in which the Kuwaiti-based Zain holds a 15.5 percent stake.

Maroc Telecom's financial health can be characterized as robust. Since partial privatization in 1998 (30 percent of equity remains with the treasury), Maroc Telecom has gone from one win to another, and today has a strong presence in nine African countries in the Maghreb and the rest of Africa through subsidiaries. The operation of its foreign branches has boosted Maroc Telecom's net earnings, which in 2017 amounted to MAD 5.9 billion. 


\subsection{Conclusion}

This chapter has shown that overall, the stock of Morocco's infrastructure has improved substantially in recent years, and rates of access to most services are high. Quantity and quality are impressive, except in a few subsectors, which are hampered by inadequate maintenance, such as roads, or underinvestment, such as broadband and sanitation. Morocco has also succeeded in attracting private sector investment in infrastructure, which helped co-finance a number of major projects. Investment in infrastructure has enabled Morocco to enjoy steady economic growth. However, there are several challenges facing Morocco's infrastructure sectors, which must be addressed for the country to continue on a strong growth trajectory. These challenges are discussed in Chapter 2. 


\section{Chapter 2. Morocco's infrastructure challenges}

While the first chapter focused on the impressive progress made by Morocco in developing its infrastructure, a number of challenges have constrained the impact of its investments and increased the reliance on fiscal support. Key challenges include weaknesses in planning, regulations, tariffs, procurement, as well as with the institutional setup, efficiency and sustainability of SOEs. And while the private sector has been involved in all the infrastructure subsectors, there is room to improve the interaction between the public and private sectors, especially if private investment is expected to reduce some of the fiscal burden in future. This remaining agenda has been acknowledged at the very highest level in Morocco. His Majesty the King, Mohammed VI, noted the inefficiencies of public services in speeches he gave on October 14, 2016, and July 29, 2017. This acknowledgement sparked increased attention on improving service delivery and the governance of public service providers. This chapter highlights areas that would need most attention.

\subsection{Planning and execution}

There are examples in the transport sector of inadequate planning and uneven application of investment blueprints that have resulted in higher costs, construction delays and sub-optimal project outcomes. While assessments of several infrastructure projects carried out by specialized firms note that costs and completion times are competitive when compared to peer countries, in some cases, infrastructure planning, budget execution and project implementation could be improved. For example, a recent report of the court of auditors (la Cour des comptes) noted that the airports office (ONDA) does not systematically respect the orientations of the schema directeur - or investment blueprint developed in coordination with its line ministry, the Ministry of Equipment, Transport, Logistics, and Water (METLE). While the schema directeur (2002-2020) provides a guide which can evolve with changes in demand, the strategic plans developed by ONDA lack details and numbers to back assumptions regarding the selected areas for development. For example, the strategic plans present capacity expansion objectives without justifying them on a case-by-case basis or providing details of the investments to be made to achieve them, which has led to poor choices in certain cases. Zagora airport was expanded in 2011 to handle 250,000 passengers, although it was not part of any schema directeur. The investment, part of a development strategy to build infrastructure necessary for regional development, was implemented as a PPP with co-financing between ONDA, the region and the province. Ultimately, the passenger volume was less than 5,000 in 2016 - about 2 percent of its capacity. There are other examples of poor planning in transport and energy. For example, most ports - with the exception of Tanger Med and Josf Lasfar - are located within cities, which has created challenges for expansion and generated tensions between the ports and surrounding cities. Table 2.1 provides other examples of poor planning and weak execution leading to reduced outcomes and higher costs.

Table 2.1. Airport Projects with Time and Cost Overruns

\begin{tabular}{|l|c|c|c|c|c|c|}
\hline \multicolumn{1}{|c|}{$\begin{array}{c}\text { Airport } \\
\text { project }\end{array}$} & $\begin{array}{c}\text { Initial } \\
\text { planned } \\
\text { date }\end{array}$ & $\begin{array}{c}\text { Actual } \\
\text { completion } \\
\text { date }\end{array}$ & Delay & $\begin{array}{c}\text { Initial } \\
\text { planned } \\
\text { budget }\end{array}$ & $\begin{array}{c}\text { Actual } \\
\text { budget }\end{array}$ & $\begin{array}{c}\text { Cost } \\
\text { overrun }\end{array}$ \\
\hline $\begin{array}{l}\text { Casablanca- } \\
\text { Mohamed V }\end{array}$ & 2011 & 2018 & 7 years & $\begin{array}{c}1.16 \text { billion } \\
\text { MAD }\end{array}$ & $\begin{array}{c}1.9 \text { billion } \\
\text { MAD }\end{array}$ & $\begin{array}{c}740 \text { million } \\
\text { MAD }\end{array}$ \\
\hline $\begin{array}{l}\text { Marrakech- } \\
\text { Ménara }\end{array}$ & 2013 & 2016 & 3 years & $\begin{array}{c}907 \text { million } \\
\text { MAD }\end{array}$ & $\begin{array}{c}1.22 \text { billion } \\
\text { MAD }\end{array}$ & $\begin{array}{c}320 \text { million } \\
\text { MAD }\end{array}$ \\
\hline $\begin{array}{l}\text { Oujda- } \\
\text { Angads }\end{array}$ & 2010 & $\begin{array}{c}\text { Put into } \\
\text { service } \\
\text { without a } \\
\text { formal } \\
\text { reception }\end{array}$ & - & $\begin{array}{c}650 \text { million } \\
\text { MAD }\end{array}$ & $\begin{array}{c}1.3 \text { billion } \\
\text { MAD }\end{array}$ & $\begin{array}{c}\text { 650 million } \\
\text { MAD }\end{array}$ \\
\hline Fes-Saiss & 2013 & 2015 & 2 years & & & \\
\hline Rabat-Salé & 2010 & 2012 & 2 years & & & \\
\hline
\end{tabular}




\begin{tabular}{|l|c|c|c|c|c|c|}
\hline Beni-Mellal & - & - & - & 96 million & 199 million & 103 million \\
& & & & MAD & MAD & MAD \\
\hline
\end{tabular}

Source: La Cours des comptes (court of auditors), 2017

While sector plans are detailed and specific, the identification and financial planning of investment projects could be improved. Every infrastructure sector in Morocco has developed strategies and plans - usually with a horizon of 2030 and with a pipeline of possible projects - but they are generally not anchored in thorough model-based or quantitative analysis. Multi-year investment planning and project development are often overlooked or examined through other processes during construction, such as the three-year budgeting program that came into effect in January 2019. Perhaps the most glaring example is the airports subsector. While ONDA has reviewed and adapted the guidelines of the master plan developed with its line ministry (METLE) to account for new air traffic trends (especially after the Open Skies reform), some airport projects were oversized, faced with budget overruns and delivered several years behind schedule. In the case of ONEE, part of its mission is to plan, manage and develop electricity transport networks and extensions to rural areas. Such planning is done in accordance with the guidelines of government and governed by various bodies within ONEE (strategy and investments committee, budgetary commission, etc.), and reinforced through the contrat programme. However, these planning functions should be part of a well-defined long-term strategy and the overall plans defined by the responsible ministry.

Some persistent weaknesses prevent the contrats programmes from being fully effective. The contrats programmes, which formalize contractual commitments, are the main tool for structuring and managing the relationship between the state and infrastructure SOEs. Firstly, they are not applied evenly across all infrastructure agencies. ONDA, for example, has never had a contrat programme with the state and has relied instead on the schema directeur, which is limited in its scope to investment rather than broader institutional commitments that could improve its performance. Secondly, the contrats programmes lack incentives for performance - such as bonuses and sanctions - that could entice both the state and public enterprises to meet their respective commitments. Third, there is often a delay in the succession of one contrat programme to another. For example, ADM's last contract was in 2015 but a new one has not been put in place. Similarly, ONEE's contract ended in $2017^{32}$ and ONCF's in 2015. New ones are being prepared but there have been gaps of over two years in the definition of priorities for these enterprises. Greater emphasis is needed on contract monitoring, evaluation and extracting lessons. There is little cross-fertilization of experiences across different agencies in the implementation of contrats programmes, which undermines the potential for improving SOE performance. Figure 2.1 shows the history of contrats programmes with selected SOEs.

\footnotetext{
${ }^{32}$ A new ONEE contrat programme is planned for the period 2019-2023
} 
Figure 2.1 History of Contrat Programmes in Morocco

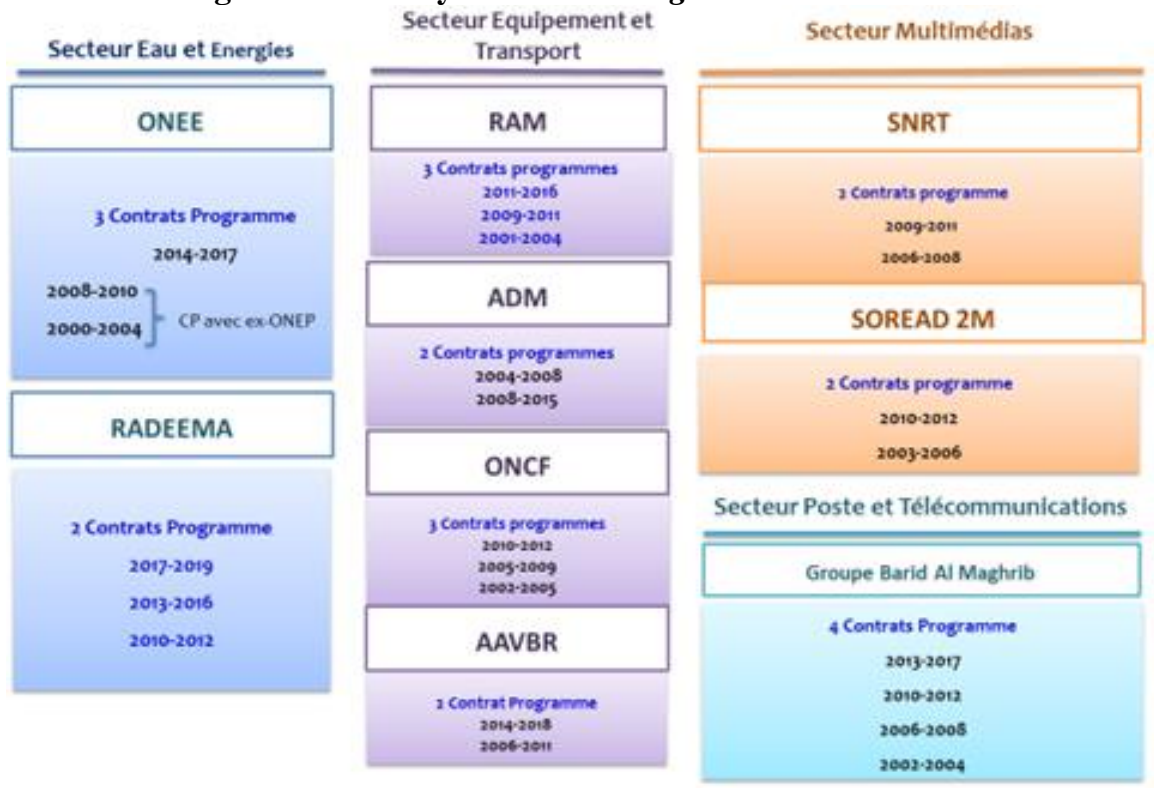

Source: Presentation of the Ministry of Economy and Finance, DEPP, July 12, 2019

\subsection{Regulation, institutional arrangements and procurement}

There is a lack of well-defined tools and processes for regulatory functions across the infrastructure sectors. There is limited transparency of technical information needed to independently assess sector performance. Authorities, at least in some sectors, have been relying on consultants to benchmark their performance; however, the information is rarely made public, reducing the scope for useful feedback from key stakeholders. Tariff reviews are conducted and decided on by the InterMinisterial Commission on Prices ${ }^{33}$ without publicly explaining the rationale for tariff levels and structures. Not enough attention is paid to the design of tariff structures, which provide differentiated prices that can be used to signal social and demand management priorities. In addition, tariff reviews are irregular, which result in accumulated financing gaps and lower cost-recovery from revenues. Financial information on several sectors is somewhat more accessible, but usually falls short of international regulatory standards. Morocco does not have regulatory accounting guidelines that for instance require operators to provide sufficient details in their cost accounting. Such detailed information is needed to improve cost recovery or to rebalance tariffs for the social good. If there is a political choice to maintain subsidies to a sector, regulations should ensure that these subsidies provide value for money to taxpayers - something that is not systematically applied in regulatory practice in Morocco.

Regulatory functions are split across different entities, and institutional responsibilities are not clear. In energy, for instance, the Ministry of General Affairs and Governance oversees issues related to price and tariff regulation while the inter-ministerial commission on prices is in charge of developing or adjusting tariff structures. Furthermore, the Ministry of Economy and Finance (MEF) assumes the licensing function, as it is mandated to grant authorizations for non-renewable energy projects. The establishment of a functional energy sector regulator has also been delayed, and although the president of the organization was recently named, the agency is not yet fully operational. In the water sector, there is no clear attribution of functions related to inter-basin transfers and water resource sharing except through information mechanisms used by water basin agencies (agences de bassins hydrauliques $\mathrm{ABH})$. Consequently, there is no arbitrator for water resources issues that cross each ABH's river basin, undermining water security at a time of increasing water scarcity. In terms of the standard functions of economic regulation, the Ministry of Interior assumes the role for municipal distribution (the Régies)

33 This commission is hosted by the Ministry of General Affairs and Governance; note this ministry was disbanded in the reshuffle of October 2019 and its functions assumed by the MEF 
in 12 cities. It also supports the monitoring of private concessions through Services Permanents de Contrôle. ONEE's governance framework is managed through its contrat prgramme and committees for strategy and investment and internal audit. With regards to ONEE's electricity services, the scope and nature of its control by the new regulator (ANRE) remains to be assessed once the agency is fully operational.

The failure to operationalize the competition council and the national anti-corruption agency could have an adverse impact on the business environment and on Morocco's ability to attract investment. The IMF noted in its latest staff report on Morocco (March 2018) that operationalizing the competition council has become urgent in order to support more private sector-led growth. While the authorities indicated that the nomination of new council members was imminent, as of September 2018 this is still a pending action. The national anti-corruption agency (l'Instance centrale de prévention de la corruption) is in a similar situation.

Procurement weaknesses have resulted in implementation gaps. For instance, there are no standardized templates for calls for tenders customized by type of procurement process. The requirement that each evaluation consist of three parts (administrative, technical, and financial) causes delays, especially as there are not enough qualified specialists to undertake the technical and financial evaluations. Examples of projects with private sector participation experiencing delays include the Agadir desalination plant and a new airport terminal at Casablanca to be executed by ONDA. In addition, there is no system for monitoring the progress of submissions, which undermines transparency and accountability. The signing and execution of contracts are often delayed-sometimes by up to twice the estimated timeline - because of missing requirements that should have been foreseen during the preparation phases, such as, the acquisition of land, inputs, supplies, or the completion of related works. That said, measures have been taken by ONDA to improve its procurement procedures, including amending its market regulations on July 9, 2014 to align the procedures with the 2014 public procurement decree, strengthening the principles of competition and transparency, and improving the definition of project consistency.

\subsection{SOEs (the principal providers of infrastructure services)}

State-owned enterprises (SOEs) have certain weaknesses. These enterprises perform numerous functions, notably infrastructure development, delivering principle public services, facilitating industrial development, and supporting poverty reduction through tariff policies. Some SOEs also engage in peripheral functions such as real estate, while others have roles that overlap with other institutions. The multiple roles have created inefficiencies and resulted in heavy financial costs (for example, managing pension liabilities). To illustrate, Autoroutes du Maroc (ADM) is nominally responsible for developing and managing highways in Morocco, but in reality, it plays the role of owner, administrator, manager, and supplier (World Bank 2016), although most of the activities linked to its role as a supplier are outsourced to private contractors. It is charged, among other things, with creating and operating tourist services, hotels, and other services alongside highways. SOEs also face challenges with procurement, as noted above.

There is a general need to clarify the internal governance structures of SOEs. The case of ONEE is illustrative. In 2012, it was restructured to combine the Office national de l'électricité (ONE), the electricity company, and the Office national de l'eau potable (ONEP), the water company. While the two companies are one entity in name, in practical terms the merger is not complete ${ }^{34}$. A revised organizational chart was not developed, and today each branch retains its original organizational structure from before the merger. It seems that ONEE has started to implement some synergies between the two main activities; however, the scope of such synergies will be probably limited to distribution and some

\footnotetext{
${ }^{34}$ It should be noted, however, that there is no ambiguity in the current internal structure of ONEE. A provisional organizational structure has been approved by ONEE's Board of Directors. What remains is to optimize the structure to realize the expected synergies (Source: ONEE)
} 
common support services. Moreover, ONEE has several internal governance committees on paper - such as the Management Committee (Comite de direction), the Ethics Committee and the Strategy and Investment Committee - but not all of them are operational, and when they are, their members do not always meet on a regular basis. The government has tried to reform SOE governance but implementation in practice has been partial. There is no good mechanism for monitoring the performance of SOEs against the code of good corporate governance practices or the recommendations of the Court of Auditors, and SOEs appear to have some discretion over the need to follow the guidelines and recommendations ${ }^{35}$.

SOE boards of directors are not as effective as they could be. These boards (conseils d'administration) decide strategic orientations and define and supervise SOE activities. Typically, they are comprised of a representative of key ministries (MEF; interior; line ministries; industry and commerce; head of government's office and other relevant ministries). There is no representation from employees, users or commercial sectors. As noted by the Court of Auditors, there is no regulatory framework specifying the conditions of appointment of state representatives on the boards of directors of SOEs (Cour des comptes, 2016); although in the case of ONEE, the regulatory framework is set by Law 40-09, which defines the conditions for the appointment of state representatives in ONEE's board. However, ONEE's board meets infrequently (approximately once a year) and does not include independent directors or representatives of employees in its activities, although committees and commissions under the board meet regularly.

A financial analysis of ten infrastructure SOEs was carried out for the period 2009-2018. The ten SOEs are: Autoroutes du Maroc (AdM) for highways; the Agence nationale des ports (ANP), the Tanger-Med special agency (TMSA) and Marsa Maroc for ports; the Moroccan Agency for Sustainable Energy (MASEN) and the Office national de l'électricité et de l'eau potable (ONEE) for electricity, water and sanitation; the Office national des chemins de fer (ONCF) for railways; and the Office national des aéroports (ONDA) for airports; and the national airline, Royal Air Maroc (RAM). The list also includes Maroc Telecom, which is technically not an SOE as defined by the MEF due to its majority private shareholding but remains Morocco's largest telecoms operator.

In 2016/17, these 10 SOEs accounted for one-third of the total revenues of all SOEs (i.e. about 100 billion dirhams for infrastructure), but have much higher levels of debt ( $3 / 4$ of the total), lower profitability ( $1 / 4$ of the total) and lower capitalization (10\% of equity), while accounting for more than 40 percent of total investments.

Over the 2014-2017 period, revenue growth was modest (+ 9\%). Other than MASEN (created in 2010), the infrastructure SOEs that experienced the strongest revenue growth over the 2014-2017 period (more than 20\%) are, in descending order, ADM, TMSA, MARSA and Maroc Telecom.

Comparing their expenses over the period 2013-2017 with the main operational parameters and workforce, ONEE and ONDA achieved the highest efficiency gains, while ONCF and RAM achieved the least.

In terms of profitability (excluding Maroc Telecom which, although evolving in a sector exposed to some competition, makes substantial profits), the net profit of the nine other infrastructure SOEs was only $1 \%$ of their turnover over the period 2013-2017. These weak earnings are mainly due to losses made by ONEE and ADM.

The capitalization of these 9 SOEs (expressed by the ratio of equity / own funds in the balance sheet at the end of 2017) is poor at 22 percent. It remains to be seen if reassessing the book value of net fixed assets changes this ratio. ONEE, with negative own funds, brings down the average as its's balance sheet value is nearly 30 percent of the 9 SOEs. MASEN ( 9 percent) and RAM (14 percent at the end of 2016) also have relatively insufficient capitalization. However, adding to the equity of ONEE the

\footnotetext{
${ }^{35}$ With regards to ONEE, action plans have been drawn up in response to the recommendations of the court of auditors, steered by a committee made up of the divisional directors
} 
investment subsidies and the sustainable provisions for risks and charges recognized in the balance sheet increases its capitalization ratio from -2 percent to +35 percent.

At the end of 2017, the total financial debt (short and long term) of these 10 infrastructure SOEs was close to 200 billion dirhams, equivalent to 19 percent of GDP. It is prudent for companies operating in market sectors to ensure that their net fixed assets are covered by equity and financial debts. By omitting the particular case of ONEE (refer above to the impact of subsidies and provisions), neither ADM nor ONCF (or for that matter Maroc Telecom) passed this test at the end of 2017 (2016 for the ADM). A calculation of financial debt to self-financing capacity of the main infrastructure SOEs for which the 2016-2017 figures are available, gives multiples of almost 10 for ADM, ONCF and ONEE. These multiples are excessive, especially in cases where the debt has been raised, directly or indirectly, in foreign currencies, which exposes these SOEs to significant exchange-rate risk.

\subsection{Implementation of PPPs}

In spite of the existing PPP legal framework, the development of a pipeline of bankable PPP projects has been slow. Since the passage of Law 86-12 on PPPs in 2014, only two PPP projects have been proposed. The first was for the construction and maintenance of the Bab Ouendar Dam, for which it was recommended that the evaluation report be revised in accordance with the regulations in force, and in particular Article 4 of Decree 2-15-45 of May 13, 2015 on PPP contracts. The second was for the construction, co-financing, operation, and maintenance of a desalination station and wind farm in Dakhla. The evaluation report has been submitted to the Minister of Economy and Finance for decision. The inter-ministerial commission in charge of PPPs is established at the MEF to give a reasoned opinion, on the basis of which the Minister makes his decision in favor or against the project. A new project to set up a pharmaceutical production unit for serum, vaccines and biological products has received a favorable opinion from the Minister.

Although the law provides a framework for the state to engage in PPPs, further efforts are needed to build a portfolio of bankable projects and attract potential investors. Amendments to the legal framework for PPPs is under review and is expected to address outstanding issues. The amendments focus on the following main areas: broadening the scope of PPPs by integrating local authorities into the law (these represent a significant potential for projects but remain outside the scope of the current law); establish a commission chaired by the Head of Government to decide, among other things, the annual PPP program; simplify the process for dealing with unsolicited proposals; and, clarify negotiation procedures.

\subsection{Sub-sector specific challenges}

\section{Transport}

\section{a) Urban transport}

Slow and congested urban public transport. Moroccan cities suffer from insufficient public transport coverage in poor neighborhoods, which tend to be located in peripheral areas linked by poor-quality roads. Moreover, the commercial speed of public urban transport as reported by operators is particularly low and unpredictable. Speeds often drop to around $5 \mathrm{~km}$ per hour on average in the densest urban areas during peak hours. This is mostly due to frequent and sometimes unnecessary stops, inefficient boarding and alighting, and congestion. An aging fleet of buses is characterized by unreliable service. There are also governance issues that undermine the quality of urban transport, including low passenger fares, limited financial resources of municipalities, and low municipal capacity to procure and manage complex projects. 
Cities have limited financial resources for urban transport, as local taxes revenues are limited. Local tax revenues are mostly from property taxation and minor licensing revenues. Despite the central government's significant investment in the light rail systems in greater Rabat and Casablanca (USD 1.3 billion), investment needs in public urban transport infrastructure remain substantial, requiring around USD 3 billion over the next decade according to the Ministry of the Interior (World Bank 2015). Cities still rely on fiscal transfers (60 percent of their budget on average) and the central government is responsible for collecting 30 percent of the national value added tax on behalf of cities. Local borrowing capacity is therefore limited. Moreover, funding for public transport is hindered by the absence of an optimal funding mechanism from the central government.

The central government's capacity to monitor urban transportation and to design and implement technical support programs for cities is still a work in progress. The Ministry of Interior's (MoI) directorate of local governments' (Direction générale des collectivités locales) division of urban mobility and transport (Division des déplacements urbains et des transports) possesses adequate expertise to provide technical guidance to cities, particularly to prepare urban mobility master plans. However, its human resources appear limited given its responsibilities. MoI also lacks necessary systems and tools (such as a strengthened central monitoring and evaluation system) to support the urban transport sector. There is a dearth of experienced and skilled staff with adequate technical expertise, despite several capacity building initiatives that proved to be worthwhile but limited in scope. Moreover, municipal services in charge of urban transport are usually overwhelmed by operational and administrative tasks. In addition, a majority of cities (especially smaller ones) have limited implementation capability since they lack experience in managing complex projects and large contracts with the private sector for civil works and services.

Experience with private concessionaires for urban bus transport has proven problematic. A bus concession concluded in 1985 for Casablanca proved disappointing. The government launched a new tendering process in 2003 and signed a contract with M'dina Bus (with RATP Development as a shareholder), the only bidder for a 15 -year concession to develop buses in greater Casablanca. This concession will not be renewed in 2019 when it ends as it has not lived up to expectations. There are several reasons for the failures. First there were insufficient financial provisions (tariffs) in the contract. Second, there was significant competition from taxis, which undercut traffic volumes for urban buses and damaged the operational profitability of the service. Third, the delegating authority was unable to meet its part of the contractual obligations such as installing bus lanes, approach lanes (couloirs d'approche), and priority access at traffic lights. Fourth, the private operator also failed to live up to its commitments and the bus fleet remains in poor condition. There was also a lack of dialogue between the private and public partners, and protests from unions and other social groups led to vandalism and higher operating costs. Stareo in Rabat was another failure, and Veolia - the private operator - left the sector altogether.

\section{b) Ports}

The Ports Law requires two different public contracting authorities, depending on the type of PPP intervention. In the case of construction, the state is the contracting authority, but for all other activities ANP is the public partner. Hence, two contracts need to be signed-one for port construction with the state and a second for operations and management with ANP — which creates inefficiencies in procurement and contract management.

Sustaining the successes of PPPs and sector reforms is a key challenge. The government of Morocco has identified several projects under its Plan portuaire 2035, including the construction of about five new ports, the extension of four others, and the improved integration of five urban ports with the rest of Morocco's cities. The five ports are: Kenitra, Safi, Jorf Lasfar and Nador West Med, all of which are under construction. The development and expansion of ports could help in spreading industrial production around the country. While it is encouraging to see a pipeline of projects, it is important to study whether there is a sound economic case for these projects. 


\section{c) Airports}

Diversified supply versus concentrated demand at airports, and poor quality of certain airport infrastructure, especially during construction. Morocco has 25 airports of which 19 are international but more than 80 percent of traffic passes through only three airports: Mohammed V in Casablanca, Marrakech-Menara and Agadir-Al Massira. A 2017 report by the Court of Auditors found that apart from these three airports, most others run net annual deficits. There are also instances of excess capacity, notably at Beni-Mellal, Oujda-Angads and Zagora. The same report also noted the poor aesthetic condition of certain infrastructure during the works phase, including at Mohammed V and Fès-Saiss airports during the construction / redevelopment phase, but which was later rectified per the recommendations of the Court of Auditors. ONDA has made considerable progress in improving passenger experience and the quality of airport infrastructure, in particular through better maintenance, which has seen increased spending from MAD 45 million in 2012 to MAD 153 million in 2018, and through additional annual spending of around MAD 30 million for the maintenance of runways and aircraft parking.

Despite a mostly good financial position, ONDA has some vulnerabilities. ONDA had debt of MAD 4 billion in 2016, of which MAD 1.1 billion (29 percent) was in foreign currency. The local currency debt is related to a bond issue in 2010 to be repaid in 2020. The agency has invested heavily in infrastructure construction in recent years and must ensure stable revenue generation and management of operating costs to meet its impending repayment obligations. Although the non-aeronautical revenues remain limited compared to the airport charges, it is worth mentioning that ONDA has recently put in place a new commercial strategy ${ }^{36}$ that aims at strengthening and developing non-aeronautical revenues ${ }^{37}$. With the exception of a handful of projects, ONDA has not systematically undertaken environmental impact assessments for airport projects, as obliged by Law no 12-03. Moreover, it has faced significant delays in developing key infrastructure, as already noted in section 2.1 (see table 2.1).

\section{d) Roads}

Deteriorating state of roads. Despite the overall high quality of roads, this has considerably deteriorated since 2002. While quantity of the road stock increased, the budget for maintenance (both periodic and routine) consequently decreased. As of 2015, almost half of the road network was deemed to be in poor shape (ministère de Transport, Plan routes 2030). The share of road length considered to be suitable for traffic declined from 66 percent in 2002 to 54 percent today, thus returning to 1990 levels (ministère de Transport, Plan routes 2030). Secondary roads (regional and provincial) have been particularly affected (World Bank 2016). The main reasons for this deteriorating performance is insufficient spending on maintenance, the impacts of climate change, and increased road traffic.

The central government's role as a network planner could be improved. In the roads sector, ADM was established in 1989 as a limited company and tasked with developing and operating roads in Morocco. Its board of directors is chaired by the Minister of Transport and is comprised of directors of major departments, MEF and its shareholders. Managerial and technical competence within ADM is considered to be high (World Bank 2016). However, while the Direction des routes used to have excellent technical capacity, this has declined in recent years. Part of the problem is the gradual retirement of its most experienced staff without plans to replace them, while other staff have left for more lucrative jobs in the private sector (World Bank 2016).

\footnotetext{
${ }^{36}$ The new strategy aims to support the transition towards a business model based on competition and favoring activities with variable fees accompanied by reassessed minimum guaranteed annuals. The "Walk Through" approach which allows to drain the maximum passengers to the shops has been also adopted for the development of new commercial galleries as well as for the rehabilitation of the old ones. Benefits of this new approach are already is some commercial galleries such as the bonded gallery of the new airport terminal in Marrakesh that has recorded an increase of the minimum commercial fees of $125 \%$ compared to the levels recorded with the old bonded gallery in 2015.

37 Non-aeronautical revenues increased from MAD 473 million in 2013 to MAD 812 million in 2018 (an average annual increase of 9.4\%) and their share in the airport turnover is constantly growing (30\% in 2016 and 32\% in 2018).
} 
ADM's financial position is fragile and could deteriorate if it continues to expand infrastructure. ADM experienced net financial losses between 2013 and 2017, reaching a low of MAD -3.9 billion in 2016. The mains reasons included some projects being undertaken for strategic rather than commercial reasons, lower volumes of traffic than expected on recently constructed roads, and an exceptional allocation for major maintenance and repair projects in 2016. Fares are also relatively low to moderate compared to other middle-income countries and are rarely raised. Moreover, the central government has asked ADM to develop many highways for "strategic" reasons" that are not commercially (and sometimes not economically) viable, which has worsened the company's financial position. ADM's debt was MAD 41 billion at the end of 2016, comprised of MAD 16.5 billion from a bond issue to finance cash flow requirements, MAD 21.7 billion of concessional loans from international financial institutions, and MAD 2.9 billion in loans from local banks. While the situation seems to have improved in 2017 as a result of a major recapitalization involving a change in the calculation of depreciation and a debt restructuring, the improvements may not last in the wake of growing investment requirements. However, despite ADM's desire to initiate a new contrat programme to widen 700 kilometers of existing highways, no new contract has been signed with the state since the last one ended in 2015 . ADM could also consider PPP approaches to roads development, although a judicious study of the areas where PPPs could add value - and make financial sense - is necessary.

\section{e) Railways}

ONCF's financial position is precarious as a result of major investment projects. At the end of 2016, ONCF's indebtedness was over 40 times cash generation with financial debt reaching MAD 26.5 billion, a 63 percent increase over 2011. In 2017, ONCF experienced a MAD 614 million loss and its debt increased by 31 percent to MAD 35 billion. About 62 percent of the 2016 debt $^{38}$ was in foreign currency (of which 45 percent was in euros), due to ONCF's borrowing from international financial institutions. The construction of the Ligne à grande vitesse (LGV) and an intense investment program in the rest of the network are the debt drivers, as these projects were mostly financed by increases to ONCF's capital allocation and debt (Table 2.2). While ONCF's operating income increased slightly ( +3 percent) between 2011 and 2016, its expenses increased by 15 percent, largely due to personnel and financing costs. ONCF receives no financial compensation from the state for the liabilities it incurs in providing transport services in peri- and interurban settings, although these have been minimized in recent years. ONCF has revisited its pricing policy by ending single fares and adjusting passenger fares within a flexible rant (yield management), notably for its $\mathrm{Al}$ Atlas and high-speed trains. This new policy allows customers to choose by class, date of purchase, date and time of travel, and offers discounts that allow customers to choose from a range of options.

Table 2.2. Evolution of ONCF's Debts (MAD millions)

\begin{tabular}{|l|c|c|c|c|c|c|c|c|}
\hline & $\mathbf{2 0 1 1}$ & $\mathbf{2 0 1 2}$ & $\mathbf{2 0 1 3}$ & $\mathbf{2 0 1 4}$ & $\mathbf{2 0 1 5}$ & $\mathbf{2 0 1 6}$ & $\mathbf{2 0 1 7 p}$ & $\mathbf{2 0 1 8 p}$ \\
\hline $\begin{array}{l}\text { Tanger } \\
\begin{array}{l}\text { Med } \\
\text { Project }\end{array}\end{array}$ & 4256 & 3937 & 3591 & 3302 & 3006 & 2676 & 2231 & 1897 \\
\hline LGV & 382 & 942 & 3032 & 5619 & 7969 & 10179 & 16015 & 17345 \\
\hline $\begin{array}{l}\text { General } \\
\text { program }\end{array}$ & 8281 & 7748 & 7617 & 7642 & 8621 & 9596 & 12159 & 12561 \\
\hline
\end{tabular}

Source: Authors' elaboration.

The planned transformation of ONCF remains unclear. ONCF is meant to undergo a reform to become a limited liability company and is likely to change its name. The legal change would entail opening up the railway sector to competition, allowing new operators to invest in infrastructure projects or form partnerships with the incumbent operator in selected services. At the same time, ONCF is planning to continue devolving all its activities with a market value to subsidiaries and retaining infrastructure aspects under its operations.

382016 numbers used for granularity, as 2017 figures were not available at the time of writing 


\section{Energy}

Reliance on imported energy. Morocco imports over 93 percent of its domestic energy needs, making it the largest energy importer in the MENA region (2017) ${ }^{39}$. Petroleum imports accounted for 20 percent of total imports and 50 percent of the trade deficit (2013) ${ }^{40}$. While Morocco is increasing the use of alternative sources of energy and reducing its dependency on fossil fuels, the country - and ONEE's financial situation - are vulnerable to fluctuations in international energy prices and supply shocks.

Grid expansion has seen an increase in network losses. The national electricity network recorded a loss of 13.4\% in 2017. While network losses in Morocco are lower than Tunisia and Algeria, they remain high when compared to Jordan and Egypt (11 percent) or Saudi-Arabia (7 percent). The losses are partly attributed to the rapid expansion of the grid and to instances of individual and collective fraud. While the expansion was necessary to absorb the supply from new renewable energy sources expected to come on board, it has been at the expense of investments in systems optimization. Promoting a more intensive share of renewable sources in the energy mix could help alleviate the pressure on the grid but this approach requires adequate financing and private sector involvement to make an impact.

Insufficient emphasis on energy efficiency. While Morocco has invested heavily in augmenting its energy supply, there has been significantly less focus on promoting energy efficiency, which is important for curbing demand, lowering investment needs in power plants, and energy imports. The Ministry of Energy, Mines and Sustainable Development adopted a national energy strategy in 2009 (updated in 2011) with a goal of achieving 12 percent of energy savings by 2020 and 15 percent by 2030. There is room to improve performance and efficiency at utility level across the chain of generation, transmission and distribution to help achieve these targets.

Despite some financial improvements of late, ONEE's financial situation is still worrisome. Electricity sales in 2017 increased by 9 percent over 2016, reaching MAD 31.5 billion (excluding valueadded tax). ONEE had a positive net income of MAD 1,570 million in 2017 (compared with MAD 790 million in 2016). Its total debt is significant at MAD 58 billion by the end of 2017, and it has pension related liabilities of MAD 28 billon. Investments over the past two decades in network expansion and rural electrification have contributed over the years to ONEE's financial difficulties. The company incurs certain risks that it cannot compensate for from other parties. As the company responsible for securing the country's electricity supply, ONEE incurs the cost of ensuring adequate capacity of and balance within the electricity network. It also takes market risk relating to variations in demand in the short, medium and long term, and is bound to meet obligations under power-purchase agreements with rigid "take or pay" clauses. Additionally, it is exposed to the risk of commodity price fluctuation (coal, natural gas, etc) with no indexing mechanism through sales price adjustments, as tariff levels and structure remain rigid.

The institutional setup of the sector has become more complex in the last 20 years. This is in large part due to the growing number of agencies and stakeholders and the absence of a regulator that can arbitrate their different - and not always aligned — interests. As can be seen in figure 2.2, ONEE is the main electricity utility in Morocco. It intervenes as an electricity distributor whenever distributors dependent on communes (régies and contracted operators) cannot provide this service. The merger of the electricity and water operations under ONEE may need to be revisited, as a new organizational structure has not been developed and each branch follows its pre-merger structure. Meanwhile, several dedicated agencies were created in order to advance reforms and boost renewable energy. These include the renewable energy agency, MASEN; the energy efficiency agency, Agence marocaine pour l'efficacité "énergétique (AMEE) ${ }^{41}$; the energy financing agency, Société d'investissement énergétique (SIE); and the renewable energy research institute, Institut de recherche en énergie solaire et en énergies renouvelables (IRESEN). The Ministry of Energy (Ministère de l'énergie, des mines et de

\footnotetext{
${ }^{39}$ Report of the Centre Marocain de la Conjoncture

${ }^{40}$ World Bank references from 2013 to 2014

${ }^{41}$ Formerly known as ADEREE
} 
l'environnement) has overall ministerial responsibility for the sector and oversees the activities of ONEE, MASEN, AMEE, and SIE. Institutional rationalization is needed to avoid overlaps in roles and responsibilities, especially with the expected decentralization of services ${ }^{42}$. For example, the Court of Auditors, among others, has expressed concern that AMEE's planning functions overlap with those of the Ministry of Energy. This is especially the case given that a 2014 decree (décret $\mathrm{n}^{\circ} 2.14 .541$ ) proposes a new department for clean energy within the ministry. Given that several entities are operating in the clean energy space, there is room for greater institutional coordination.

Figure 2.2 Institutional Structure of Morocco's Electricity Sector, 2017

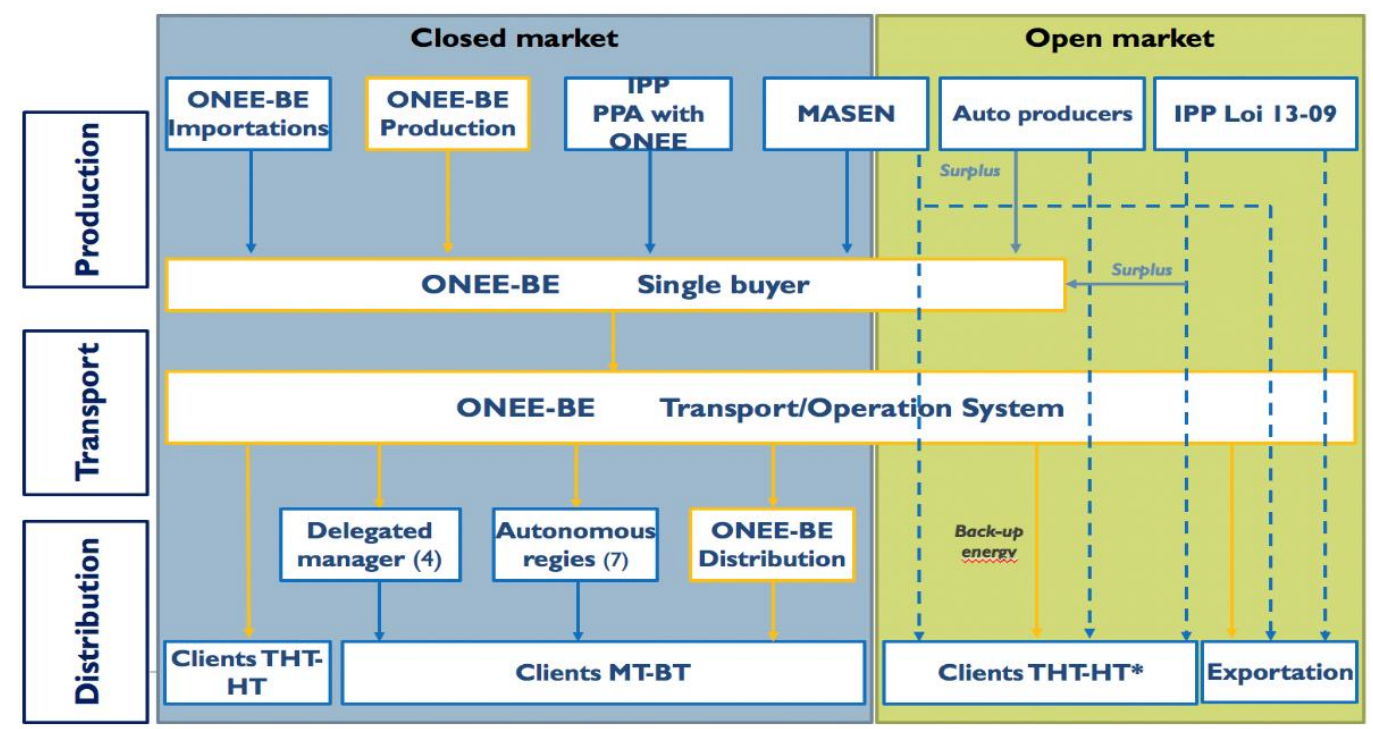

Source: Diagnostic EP, Secteur de l'Electricité, ONEE.

Note: ONEE-BE = ONEE Electricity Branch; IPP = Independent Power Producer; THT = Very High Tension; $\mathrm{HT}=$ High Tension; $\mathrm{MT}=$ Medium Tension; $\mathrm{BT}=$ Low Tension .

Progress in restructuring the sector has been slow. According to the Global Power Sector Reform Index, Morocco is ranked 55 out of 88 on four dimensions of reform (regulation, competition, private sector participation and restructuring). The areas of weakest reform efforts are regulation and restructuring. When compared with its middle-income peers, Morocco's performance in enhancing competition is not that strong. Countries like Argentina, Turkey, Guatemala and Mexico have all done more to promote competition in their power sectors than has Morocco.

For the initial 3 projects in the solar plan, the offtaker model used by MASEN for IPPs requires significant government support to attract private investment. For the initial three projects, MASEN is a loss-making off-taker that signs power purchase agreements with private operators bidding on tenders, and with ONEE. It pays a certain price to the electricity producers and then resells the electricity to ONEE at a lower price, absorbing the loss. These initial projects required this financial support to kick-start the renewable energy market, but growing competition and technological improvements are expected to enable diversified funding sources in future resulting in a more balanced economic model.

The establishment of the independent regulator has been slow. The establishment of a regulator for the energy sector was first conceived in 1997 and enabled in 2015 with the passing of Law 48-15, which proposed the creation of the Autorité nationale de regulation de l'électricité (ANRE). In its initial phase, the role of the agency is to establish and oversee the conditions and rules governing the integration of renewable energy projects into the grid, and to ensure overall good governance of the sector. ANRE's president was named but the agency is not yet fully operational. If well structured, it could increase the attractiveness of the power sector for private actors while ensuring competition, transparency, and smooth functioning of a liberalized electricity market. One important challenge will be to define the

${ }^{42} \mathrm{~A}$ study is underway on this topic (Source: ONEE) 
scope of regulation (i.e. in terms of sector functions; existing concession contracts; etc.) and organize it in a sector with very different players (a national operator; municipal public operators and private concessionaires).

\section{Water}

It is possible to improve water supply and sanitation service levels in rural areas. Although the official figure provided by ONEE for access to drinking water (97 percent in rural areas) is impressive, there are opportunities to improve the level of water services by switching from public to household connections, provided consumers are willing to pay for the service. Work remains to be done to improve sanitation coverage in rural areas, where access to basic sanitation is 79 percent. Although the number of households practicing open defecation decreased by more than half (from 16 percent in 2007 to 7 percent in 2017), the percentage of households using on-site sanitation facilities such as septic tanks, cesspools, or latrines has not evolved much.

The water sector is highly fragmented, with several public actors, multiple levels of governance, and a variety of market participants, both public and private. At state level, the water sector is under the overall responsibility of the Ministry of Equipment, Transport, Logistics, and Water (METLE), although state supervision of ONEE is exercised by the Ministry of Energy, Mines and Sustainable Development. Until recently, a dedicated secretariat for water (Secrétariat d'état à l'eau) was in charge of water issues, with some autonomy from METLE but this statute was reversed by a government decision in August 2018 that eliminated the secretariat. Other ministerial departments are also involved in the water sector such as the Ministry of General Affairs, Ministry of the Interior, and Ministry of Economy and Finance. The Ministry of the Interior oversees municipal service providers in the public sector (régies autonomes), as well as private distributors granted concessions by municipalities (World Bank 2017). There is therefore a need to improve coordination between agencies in the water sector to respond to the demands of the population and industry in a manner that does not affect the sustainability of service delivery. Given the different nature and role of various sector players, organizing sector regulation is another challenge.

Tensions between the cost of service and the policy of tariff equalization has reduced the selffinancing capacity of the sector. In urban areas, the volume of water billed at the "social" rate constitutes a substantial part of volume distributed, and for which the selling price is considerably lower than the cost. A drop in domestic consumption has been observed in several cities after the increase in the tariff for large consumers, leading to a reduction in operator margins. In Casablanca, for example, municipal consumption has dropped by 90 liters / person / day to 87 liters between 1997 and 2018, while planning documents provided for an increase to 120 liters. Similar trends are observed in Agadir and Settat. Consequently, infrastructure renewal needs are only partially funded, which has delayed the achievement of network investment targets.

The tariff system in place does not generate adequate resources to finance and maintain the infrastructure to mobilize water resources. The government's primary concern is to ensure access to water services (drinking water, sanitation and irrigation) for the entire population, and it regulates tariffs for this purpose. This in turn drives the revenues public service providers (ONEE water and electricity, and the regional agricultural development offices). Moreover, in the context of a delicate hydrological situation, any reduction in resource allocations to users (ONEE or ORMVA) results in revenue loss or additional costs to compensate for these reductions, which should technically be reflected in the price of services. 


\section{$\mathrm{ICT}^{43}$}

The Government has prepared, but has not yet officially adopted, the Morocco digital strategy. Obtaining government approval for a digital economy strategy driven by wide access to broadband is a priority. This should be done in cooperation with the sector's main stakeholders and following an open and participatory process.

Mobile telephony, once a growing segment of the ICT sector, is starting to show signs of saturation and stagnation. The penetration rate of mobile telephony (number of SIM cards in relation to the population) was 127 percent in 2018 (National Telecommunications Regulatory Agency - ANRT, 2019), but the market is no longer growing, which explains along with the fall in retail prices, the decline in operator revenues (World Bank, 2016). According to the annual report of the International Telecommunication Union, the annual turnover of the sector has decreased from 3.8 billion USD in 2014 to 3.2 billion USD in 2016. Despite the 127 percent penetration rate based on the number of SIM cards, the penetration rate based on single subscribers remains close to 68 percent, suggesting that there is still potential for growth, especially in the post-paid segment which accounts for only 9 percent of subscribers (ANRT, 2019). The price of incoming international calls remains very high: in 2019, the price of a Skype Out call to Morocco was 17 times higher than in France ${ }^{44}$.

While broadband is the driving force behind the digital economy, penetration remains low despite some recent improvements. In 2018, the ANRT estimated that the internet penetration rate was 64 percent of the population (compared to 50 percent in 2016), which is lower than that estimated by the regulator in Senegal at 68 percent. However, international databases suggest much lower rates for both Morocco and Senegal ${ }^{45}$. There is also an urban-rural divide, with 82 percent of urban households having access to the internet compared to 56 percent in rural areas (ANRT, 2019). In addition, broadband infrastructure coverage is significantly lower in secondary cities than in large cities ${ }^{46}$.

To enable the large-scale development of the digital economy, Morocco should continue to accelerate the development of broadband, which faces three major obstacles:

- Lack of competition: Morocco continues to limit the entry of actors who would like to deploy their own infrastructure without commercializing the broadband frequencies. Compared to other countries in sub-Saharan Africa, such as Senegal, Morocco has no internet service provider licensed to deploy its own infrastructure, nor infrastructure wholesale operators or virtual mobile network operators. Hence, the broadband market is controlled by the three existing operators. In addition, competition is not exercised across all geographical areas covered because of an imbalance in terms of fiber optics infrastructure between the three existing operators: in 2016 it was estimated that Itissalat Al Maghrib has a fiber optic backbone of nearly 25,000 km compared to 5,000 km for Meditel and 6,000 km for WANA.

- Lack of regulation: Despite notable efforts and recent decisions by ANRT in 2018 and 2019, broadband infrastructure regulation (ADSL and fiber optics) does not cover certain essential aspects, such as the international connectivity and fiber optics markets. Furthermore, free access to fiber optic networks belonging to alternative infrastructure operators (ONEE, ONCF) is another major regulatory challenge to which Law 121.12 has brought improvements but which have not yet been implemented.

\footnotetext{
${ }^{43}$ This section benefited from the written comments from the ANRT team received on May 6, 2019.

${ }^{44} \mathrm{https}$ ://www.skype.com/fr/calling-rates/Morocco (June 24, 2019).

45 This is explained by different calculation methods due to different definitions of internet access.

${ }^{46}$ ANRT does not publish a network coverage map, but the www.nperf.com site illustrates differences in digital access between cities and within cities
} 
- Limited use of the Universal Service Fund (USF): At the end of 2016, it was estimated that the use of the (USF), which is financed by 2 percent of the total turnover of operators, has not been sufficiently orientated towards broadband development: (i) USD 288 million was still available at the USF; (ii) a total of 6 projects have been initiated by the USF since its inception in 2005 but most of them are in the education sector; (iii) none of the USF projects have significantly funded the deployment of broadband infrastructure in neglected areas. As indicated by the ANRT in May 2019, very large broadband projects were adopted in December 2017 by the management committee of the USF following consultation with the licensed operators, in order to solicit proposals to use the funds of the USF to co-finance fiber optic infrastructure in geographical areas eligible for universal service. However, this consultation is still ongoing and is expected to conclude with a call for proposals $^{47}$.

\subsection{Conclusion}

While the achievements have been substantial, this chapter has discussed important challenges that impact all four infrastructure sub-sectors in Morocco, notably with respect to planning, procurement, organization, and the institutional set up and oversight of SOEs. Progress in each of these areas could improve the efficiency of the infrastructure sectors, the impact of investments, and reduce unit costs.

Finally, strengthening the regulatory framework could promote efficiency gains through benchmarking, and help improve tariff setting and cost recovery. Actions to increase the sustainability of the SOEs and better use of the contrats-programmes to monitor progress would help strengthen SOE performance. The ability of the government to pursue its ambitious agenda without loss of momentum will depend on its ability to address these infrastructure sector challenges.

${ }^{47}$ https://www.anrt.ma/publications/appels-doffres/consulter-les-appels-doffres 


\section{Chapter 3. Morocco's infrastructure investment \& spending needs}

This chapter reviews past infrastructure spending, based on a public expenditure review carried out as part of this analysis and drawing on government data. It then presents scenarios for future investment and spending needs of the various infrastructure-related sectors and highlights specific pressing infrastructure challenges. In the face of these needs, this chapter then outlines the macro-economic and fiscal constraints that may curtail the government's ability to continue financing infrastructure through public debt.

\subsection{Historical trends in infrastructure spending}

Morocco has benefited from high and increasingly stable rates of economic growth in recent decades. Over the period 2010-2017, GDP grew by 3.6 percent per annum, and in preceding decades by 4.7 percent $2000-2009$ and 3.2 percent $1990-1999$. On a per capita basis, after increasing by around 1.5 percent on average between 1989 and 2000, growth doubled reaching an average of 3.1 percent between 2001 and 2017 (World Bank, Pinto, 2019). The fluctuation, as measured by the standard deviation of GDP growth, dropped from 6 in 1990-99 to about 1.8 in 2000-2017 (MEF 2019). Domestic demand has been the main driver of growth. There have been structural changes to the economy with a decline in the share of agriculture and manufacturing in GDP and an increase in tertiary sector participation (mainly telecommunications and financial services) and off-shore activities. Domestic demand has supported growth through expanded consumption and high levels of public investment through state-owned enterprises (Pinto, 2019).

Between 2011 and 2017, infrastructure SOEs spent an average of about 11.2 percent of GDP) on infrastructure. This estimate is derived from data from the MEF based on investment expenditure of 10 infrastructure SOEs (AdM, ANP, MASEN, Maroc Telecom, Marsa Maroc , ONCF, ONDA, ONEE, RAM, TMSA). Of the total of 11.2 percent, 2.8 percent is for new capital investments (CAPEX) and 8.4 percent is for operating costs. This figure does not include investments by private sector and local governments, which would add to this number. Overall investment in the Moroccan economy has also been high; Between 2001 and 2017, total investment fluctuated between 25\% and 38\% of GDP, one of the highest investment rates in the world. Table 3.1 summarizes the numbers examined.

Table 3.1 Actual spending by main infrastructure SOEs in recent years (\% of GDP)

\begin{tabular}{|l|c|c|c|c|c|c|c|c|}
\hline & $\mathbf{2 0 1 3}$ & $\mathbf{2 0 1 4}$ & $\mathbf{2 0 1 5}$ & $\mathbf{2 0 1 6}$ & $\mathbf{2 0 1 7}$ & $\mathbf{2 0 1 8}$ & $\mathbf{2 0 1 9}$ & $\begin{array}{c}\text { Average } \\
\mathbf{2 0 1 3}-\mathbf{1 7}\end{array}$ \\
\hline $\begin{array}{l}\text { Operating } \\
\text { expenditure }\end{array}$ & $\mathbf{8 . 2 \%}$ & $\mathbf{8 . 3 \%}$ & $\mathbf{8 . 6 \%}$ & $\mathbf{8 . 8 \%}$ & $\mathbf{8 . 3 \%}$ & & & $\mathbf{8 . 4 \%}$ \\
\hline Electricity and W\&S & $3.6 \%$ & $3.7 \%$ & $3.6 \%$ & $3.4 \%$ & $3.4 \%$ & & & $3.5 \%$ \\
\hline Transport & $2.6 \%$ & $2.6 \%$ & $2.6 \%$ & $2.9 \%$ & $2.6 \%$ & & & $2.7 \%$ \\
\hline ICT & $2.0 \%$ & $2.0 \%$ & $2.4 \%$ & $2.4 \%$ & $2.3 \%$ & & & $2.2 \%$ \\
\hline Capital expenditure & $\mathbf{2 . 5 \%}$ & $\mathbf{2 . 3 \%}$ & $\mathbf{3 . 3} \%$ & $\mathbf{2 . 9 \%}$ & $\mathbf{2 . 2} \%$ & $\mathbf{2 . 5 \%}$ & $\mathbf{2 . 7 \%}$ & $\mathbf{2 . 8 \%}$ \\
\hline Electricity and W\&S & $0.9 \%$ & $0.9 \%$ & $1.1 \%$ & $1.0 \%$ & $0.6 \%$ & $1.1 \%$ & $0.9 \%$ & $0.9 \%$ \\
\hline Transport & $1.5 \%$ & $1.4 \%$ & $1.7 \%$ & $1.5 \%$ & $1.1 \%$ & $1.4 \%$ & $1.8 \%$ & $1.4 \%$ \\
\hline ICT & $0.0 \%$ & $0.0 \%$ & $0.5 \%$ & $0.4 \%$ & $0.4 \%$ & & & $0.4 \%$ \\
\hline TOTAL & $\mathbf{1 0 . 6 \%}$ & $\mathbf{1 0 . 6 \%}$ & $\mathbf{1 1 . 9 \%}$ & $\mathbf{1 1 . 7 \%}$ & $\mathbf{1 0 . 5 \%}$ & $\mathbf{2 . 5 \%}$ & $\mathbf{2 . 7 \%}$ & $\mathbf{1 1 . 2 \%}$ \\
\hline
\end{tabular}

Source: Ministére de l'Economie et des Finances (MEF) reports on SOEs.

https://www.finances.gov.ma/fr/Pages/Gestion-entreprises-publics.aspx?m=NOS\%20METIERS and Blanchard (2019). Data for 2018 and 2019 are provided as indications of trends according to the budget.

In addition to the above numbers drawn from actual government spending data, a parallel analysis was carried out to estimate new capital expenditure (CAPEX) and renewal CAPEX based on the approximate value of assets and using international unit costs (note this approach is based on economic rather than accounting principles). This also reveals high spending on CAPEX investment and renewal. 
Table 3.2 presents the results of this modeling, and Appendix $\mathrm{C}$ provides the methodology used to estimate these scenarios. Note that the model excludes operating costs such as fuel and salaries.

Table 3.2 Historical spending on infrastructure using international unit costs

\begin{tabular}{|l|c|c|c|c|c|c|c|c|c|}
\hline & \multicolumn{3}{|c}{ New CAPEX } & \multicolumn{3}{c|}{ Renewal CAPEX } & \multicolumn{3}{c|}{ Total } \\
\hline & $\begin{array}{c}\mathbf{1 9 8 5 -} \\
\mathbf{1 9 9 0}\end{array}$ & $\begin{array}{c}\mathbf{1 9 9 5 -} \\
\mathbf{2 0 0 5}\end{array}$ & $\begin{array}{c}\mathbf{2 0 0 5 -} \\
\mathbf{2 0 1 5}\end{array}$ & $\begin{array}{c}\mathbf{1 9 8 5} \\
\mathbf{1 9 9 0}\end{array}$ & $\begin{array}{c}\mathbf{1 9 9 5 -} \\
\mathbf{2 0 0 5}\end{array}$ & $\begin{array}{c}\mathbf{2 0 0 5 -} \\
\mathbf{2 0 1 5}\end{array}$ & $\begin{array}{c}\mathbf{1 9 8 5 -} \\
\mathbf{1 9 9 0}\end{array}$ & $\begin{array}{c}\mathbf{1 9 9 5 -} \\
\mathbf{2 0 0 5}\end{array}$ & $\begin{array}{c}\mathbf{2 0 0 5}- \\
\mathbf{2 0 1 5}\end{array}$ \\
\hline Transport & 1.0 & 2.0 & 1.1 & 3.1 & 2.8 & 2.6 & 4.1 & 4.8 & 3.7 \\
\hline ICT & 0.4 & 0.6 & 0.5 & 0.1 & 0.3 & 0.4 & 0.6 & 1.0 & 0.9 \\
\hline Electricity & 0.9 & 1.1 & 1.2 & 0.9 & 0.8 & 0.8 & 1.8 & 1.9 & 2.1 \\
\hline W\&S & 0.2 & 0.2 & 0.1 & 0.2 & 0.2 & 0.2 & 0.4 & 0.4 & 0.3 \\
\hline TOTAL & $\mathbf{2 . 5}$ & $\mathbf{3 . 9}$ & $\mathbf{3 . 0}$ & $\mathbf{4 . 4}$ & $\mathbf{4 . 1}$ & $\mathbf{4 . 1}$ & $\mathbf{6 . 9}$ & $\mathbf{8 . 0}$ & $\mathbf{7 . 0}$ \\
\hline
\end{tabular}

Based on a model of valuation of infrastructure stocks

\section{2_ Assessing future needs}

Setting up and comparing various scenarios can help forecast investment needs. Even though forecasting investments is a subjective exercise, it helps to identify the factors behind stated needs and resources needed to fulfil these needs. Single-number estimates of infrastructure investment needs can indeed be misleading but comparing a baseline with a high estimate provides a range of possible costs and the magnitude of commitments to be made by authorities to either maintain long term trends or to increase the level of investment. It also allows decision makers to compare the implications of decisions relating to policy objectives. This report provides a high estimate for Morocco's investment and spending needs in the years to come compared with a baseline extrapolating long term trends.

Note that budget allocations for infrastructure must be accompanied by the appropriate policy and regulatory measures to increase their impact ${ }^{48}$.

\subsection{Infrastructure spending scenario}

Using an infrastructure stocks valuation model, a scenario analysis was prepared showing estimates of spending. A baseline and a high estimate show a range of projected spending based on assumptions about costs and other parameters but are not built on an analysis of actual or objective needs for every sector. A needs analysis would define priorities based on the country's social, economic and environmental objectives. These estimations are meant to initiate a policy dialogue not to replace sector planning and modelling. Refer to Appendix $\mathrm{C}$ for the methodology used to derive the estimates.

(i) A scenario based on the 30-year average (1985-2015) or "Baseline Scenario": The annual change in infrastructure stocks over the period 1985-2015 multiplied by the international unit costs of infrastructure stocks in 2016.

(ii) A scenario targeting the $\mathbf{4 0}^{\text {th }}$ percentile of infrastructure stocks in upper middle-income countries by 2030 or "High Growth Scenario": The yearly evolution of infrastructure stocks is computed for Morocco to reach upper-middle-income countries' 40th percentile of infrastructure stocks by 2030, as assessed in 2015. This figure is again multiplied by 2016 international unit costs for the construction of infrastructure.

These estimates suggest a range of expenditure needs from 11.5 percent to 18.3 percent of GDP (investment, renewal CAPEX and operating cost expenditure). The analysis provides estimates of future investment and renewal CAPEX spending. Operating costs (OPEX - such as fuel and salaries)

\footnotetext{
${ }^{48}$ International evidence shows that the welfare multipliers from investment in infrastructure are sensitive to the reaction of growth output elasticity to investment in infrastructure. This elasticity is highly sensitive to the quality of institutions, policies, and regulation.
} 
are estimated at 4 percent, being the difference between total operating expenses of SOEs (assumed to include renewal CAPEX in Table 3.1) and estimates of renewal CAPEX alone from the economic model in Table $3.2^{49}$. As in all countries with large infrastructure stocks, renewal CAPEX is essential to maintain service delivery levels. Table 3.3 presents the results of this scenario analysis.

Table 3.3 Scenarios of future infrastructure spending (\% of GDP)

\begin{tabular}{|l|c|c|c|c|}
\hline & $\begin{array}{c}\text { Investment } \\
\text { CAPEX }\end{array}$ & Renewal CAPEX & OPEX & Total \\
\hline Baseline scenario & 3.4 & 4.1 & 4.0 & 11.5 \\
\hline High-growth scenario & 9.9 & 4.4 & 4.0 & 18.3 \\
\hline
\end{tabular}

The baseline growth scenario resembles Morocco's current spending on infrastructure, but spending will likely need to accelerate if Morocco is to catch up with higher income countries and meet some of the pressing needs discussed in the next section.

\subsection{Signs of the increase in demand}

Demand for infrastructure continues to grow across all sectors, putting pressure on existing assets. The principal drivers of this demand are population growth, increased urbanization, and improved per capita income levels. Some of the demand growth has been quite rapid. Port traffic increased steadily, at an annual rate of 6 percent between 2000 and 2010 due to national growth, steady investments, and an official policy of integrating Morocco's economy with regional and international markets. In 2017, air traffic exceeded 20 million annual passengers for the first time (ONDA 2018). Figure 3.1 illustrates this trend (even though the data provided is only until 2011, the trend has continued in a general upward direction since then). Electricity demand has been increasing at an annual average rate of around 7 percent since 2002, far above economic growth rates, while the demand for drinking water has been increasing at an average pace of 3.4 percent per year. The latter is of concern for a country with renewable freshwater resources of 625 cubic meters per capita ${ }^{50}$, below the threshold of 1,000 cubic meters defined as water scarcity. In the ICT sub-sector, there are demands for increased broadband access, as 35 percent of the population does not yet have access to the service, due to high cost and lack of competition.

Figure 3.1 Evolution of Road, Rail, and Air Traffic in Morocco, 2000-11

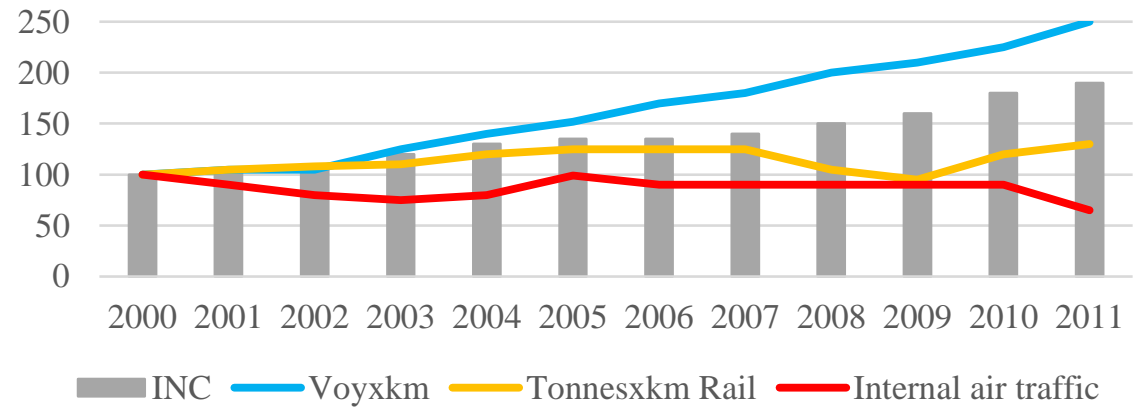

Source: Ministère de Transport, Plan Route 2030.

Figure 3.1 (b) Evolution of Air Passenger Traffic in Morocco 2005 - 2018

\footnotetext{
${ }^{49}$ Note that the figure of 4 percent is not based on an evaluation of actual operating costs

50 Source : Water department, Morocco (Le département de l'eau) for 2018
} 


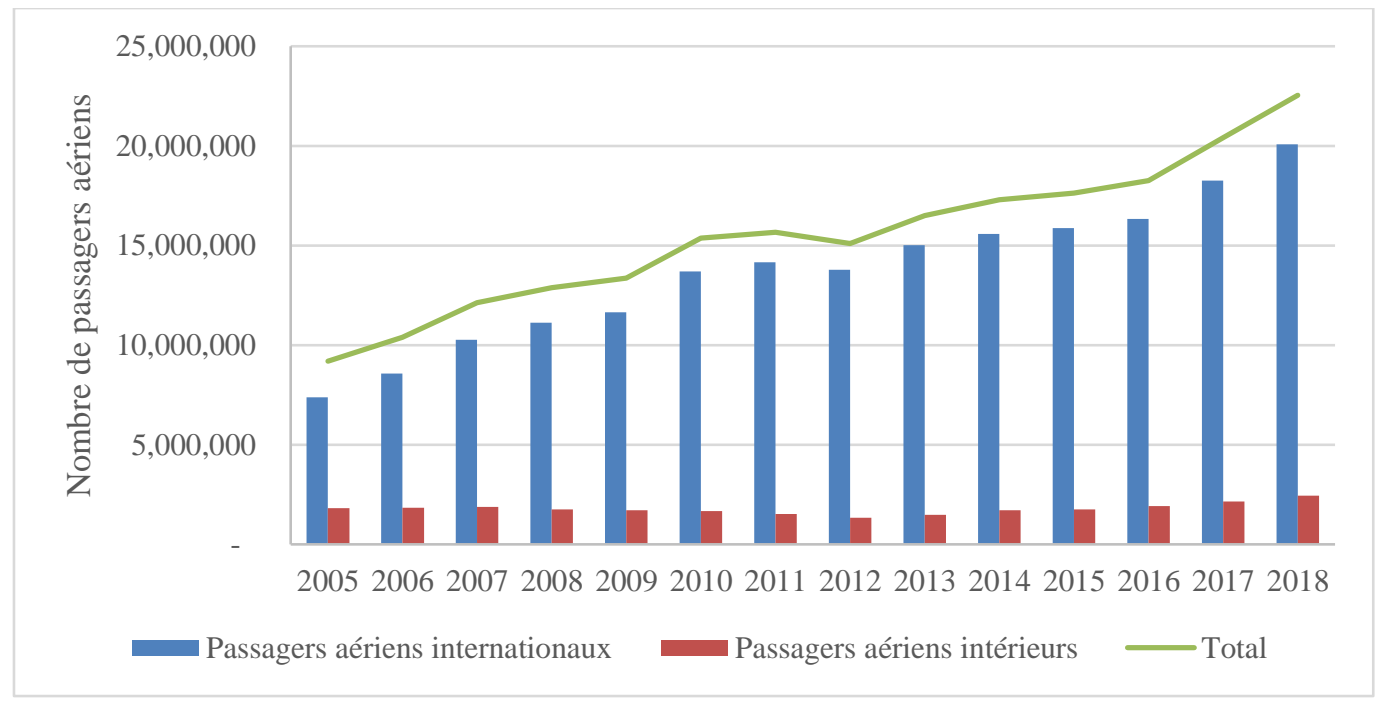

Source: ONDA statistics.

Electricity demand has been increasing at an annual average rate of around 7 percent since 2002, while reserve margins are low. Almost 74 percent of this growth in demand has been met with electricity from fossil-fuel-based power plants and 14 percent with imports from Spain. Demand peaked at 5,860 MW in 2015 due to the increased use of air-conditioning, which reduced the country's reserve margins to an amount closer to a total installed capacity of 8,158 MW. However, it should be noted that the rate of increase in demand for electricity has decelerated since 2015 due to the gradual increase in prices, improving energy efficiency and supporting the universal access agenda.

As a result of successive droughts and reduced water availability, pressure on water resources has increased over the past decades. Morocco's renewable freshwater resources is currently at 625 cubic meters/capita/year, well below the global water scarcity threshold of $1,000{ }^{\text {cubic }}$ meters/capita/year (Figure 3.2). About 70 percent of the population is exposed to high or very high surface water stress and 12 percent to groundwater stress (World Bank, 2018). Chronic water shortages have sometimes led to social frustrations, as evidenced most recently by the "thirsty protests" organized by residents in southern Morocco in the summer of 2017. According to a 2013 World Bank study, climate projections in Morocco have shown that climate change is likely to result in (i) an increase in summer temperatures of up to $3.7^{\circ} \mathrm{C}$ by 2030 , and (ii) a reduction in rainfall in the region by 5 to 15 percent by 2030 and 10 to 25 percent by 2050 . The $3^{\circ} \mathrm{C}$ increase in temperature and 15 percent reduction in rainfall by 2030 could reduce the available groundwater recharge by 33 to 45 percent and thus reduce the amount of groundwater that can be used sustainably.

Figure 3.2 Decreasing Availability of Water in Morocco, 1960-2020

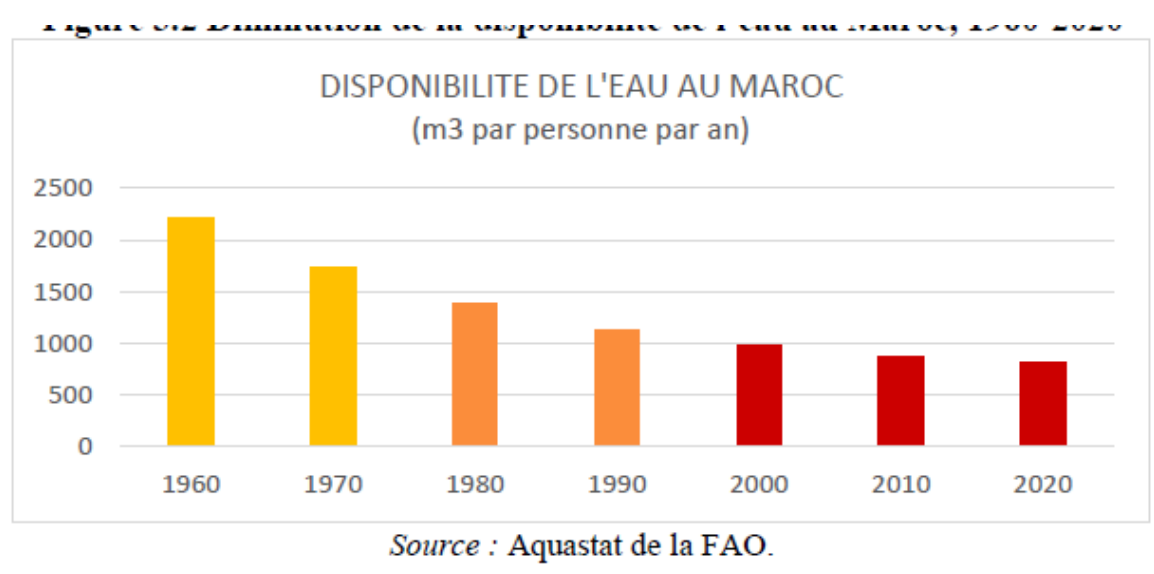


The financing needs for the water sector are enormous and the marginal cost of investments in supply will increase significantly in the future. According to figures from the Directorate of Budget, the state has allocated 10 billion dirhams a year from the general state budget to finance the water sector, of which an average of 7 billion dirhams is for the authority responsible for water resources (dams, transfers, flood control) and 3 billion for drinking water and sanitation. The program for savings in irrigation water consumes around 4 to 5 billion dirhams per year. The infrastructure stock, accumulated over more than a century, valued at cost adjusted for inflation exceeds 100 billion dirhams for just dams. Implementation of the national water plan (Plan national de l'eau) 2015, requires investments and associated financing in excess of 261 billion dirhams for the period $2013-2030$.

Climate change is already having tangible impacts on Morocco's infrastructure and calls for a change in approach to infrastructure development. Morocco has suffered extreme weather events in recent years, notably the 2014 floods, which have compromised the structural integrity of many road networks. Extreme temperatures could accelerate the degradation of paved roads, calling for improved asset monitoring and regular maintenance and upgrades to road infrastructure. However, the impact of climate change in the roads sector has so far been overlooked, particularly as far as maintenance is concerned. Another sector that has been severely affected by climate change is water. Although Morocco is a water-scarce country, it has up to now managed to ensure basic water services for domestic, industrial and agricultural purposes. Climate change is expected to exacerbate water scarcity, and the rapid growth of Morocco's coastal cities - especially Casablanca and Agadir - as well as Marrakesh, will put significant strains on basic water supply. There is therefore a need for both improved water resources management, particularly groundwater, and alternative sources of water (such as desalination and reuse of treated wastewater) to avoid water shortages and service disruptions, all while evaluating the costs and financing mechanisms to support such investments. In particular, the high cost of mobilizing unconventional resources (e.g. desalination, wastewater, etc.) requires rethinking the economic model. Better water governance, demand management and improvements in efficiency are needed to ensure cost-effective water supply.

Finally, continued infrastructure investments in rural areas will be essential in reducing regional disparities. Poor households are concentrated in rural areas. In 2014, 63 percent of poor households were in six administrative regions that represented 36 percent of Moroccan households. ${ }^{51}$ The fact that these same regions represented 60 percent of Morocco's poor population in 2007 emphasizes the extent and persistence of geographical disparities. This is illustrated in figure 3.3.

Figure 3.3 Population distribution and poverty, 2014

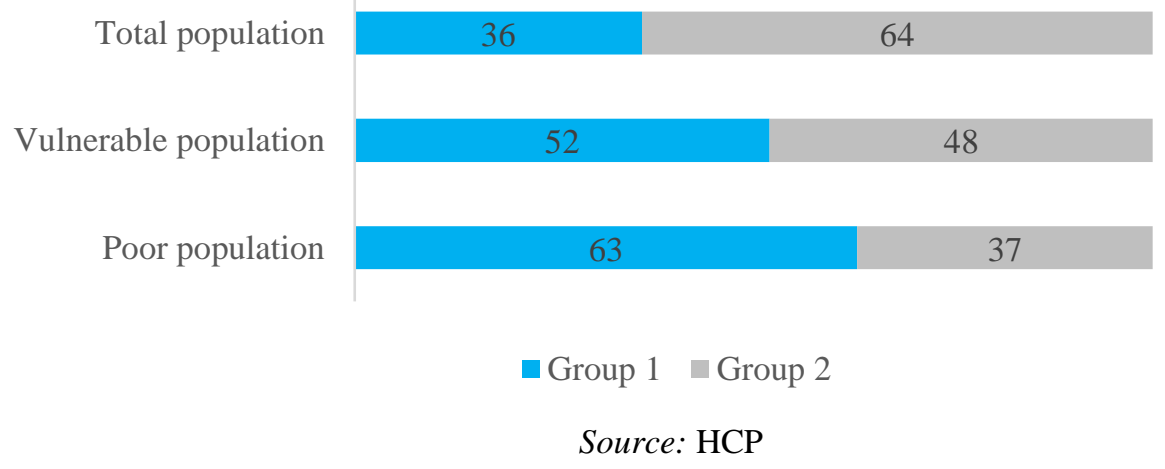

Group 1: Tadla-Azilal; Meknes-Tafilalet; Gharb-Chrarda-Beni Hssen; Taza-Al Hoceima-Taounate; DoukalaAbda; Sous-Massa-Daraa.

Group 2: Fez-Boulemane; Chaouia-Ouardigha; Marrakesh-Tensift-Al Haouz; Rabat-Sale-Zemmour-Zaer; Tangier-Tetouan; Grand Casablanca.

51 These regions were Souss-Massa-Daraâ; Gharb-Chrarda-Beni Hssen; Doukala-Abda; Tadla-Azilal; Meknès-Tafilalet; and Taza-Al Hoceima-Taounate. In 2015, the initial 16 regions in Morocco were restructured into 12 new administrative regions. 


\subsection{Macro-economic and fiscal constraints}

The macroeconomic and fiscal situation is becoming more challenging. The ratio of state debt to GDP of 65 percent - above the 58 percent unweighted average for the MENA region - represents a potential source of concern if the government must increase its borrowing to finance infrastructure. With a projected increase in global interest rates, the cost of external debt service would increase, making borrowing less sustainable. As illustrated in figure 3.4, Morocco relies heavily on domestic debt, representing 50 percent of GDP, while external public debt is at 14 percent of GDP, with interest payments at 2.6 percent of GDP. While 78 percent of the domestic debt is denominated in local currency, there has been growth of corporate external debt, which reached 20 percent in 2017. The government's ability to control debt depends on its ability to contain current spending, enhance tax revenues, boost productivity, and address unemployment (which was 10 percent nationwide in 2017) and social tensions. A key challenge is controlling the wage bill, which represents more than 10 percent of GDP. Improvements in revenue will depend on the ability to implement comprehensive tax reform including measures to reduce tax exemptions, lower corporate tax rates, and better enforce the taxation requirements of the self-employed and of liberal professions.

Figure 3.4 Public Debt (\% of GDP)

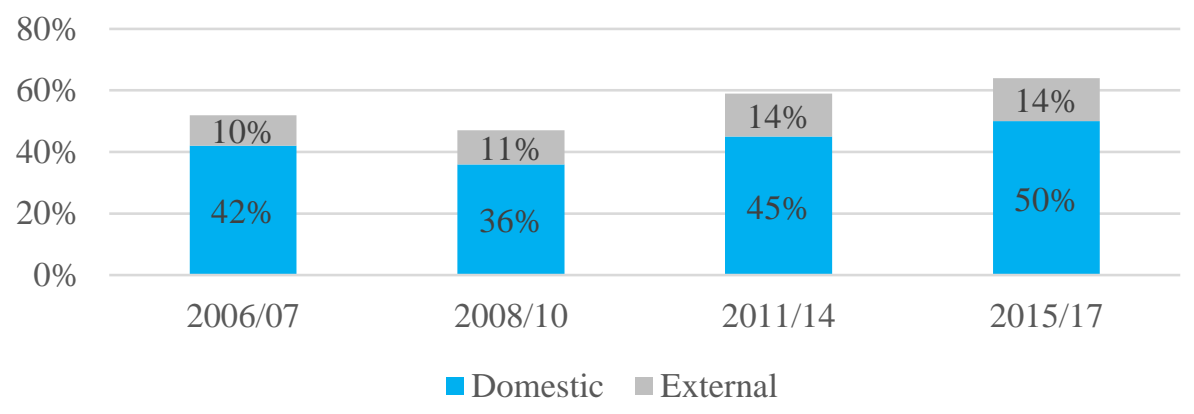

Source: International Monetary Fund.

The reduced fiscal space underlines the need for reforms to augment the impact of investments. Given the increasingly constrained fiscal space, the government should accelerate reforms aimed at making gains in efficiency, improving planning and execution, reducing unit costs and reducing the overall level of subsidies to the infrastructure sector. Better spending should be one of the principle areas of focus, especially in the construction of infrastructure. Reducing costs and carrying out lifecycle costing analysis ${ }^{52}$ will enable Morocco to enhance value for money in infrastructure spending over the long-run. As SOEs are the main vehicles for public infrastructure spending, they are the natural target for efficiency improvements.

In addition, given the constraints on public resources, the government will need to increasingly leverage private sector investments through PPPs, as well as increase the mobilization of resources from local financial markets. Well-structured PPPs and other forms of private sector participation can also bring efficiency gains through modern management methods, improved operations and innovative technology. In addition, SOEs that are run on a commercial basis should increasingly be able to issue and manage non-guaranteed or partially guaranteed debt.

Finally, decentralization of investments could help manage the fiscal space. The 2011 Constitution envisages a new approach to empower regions to play a greater role in economic development. For now, the regional development plan envisions an increase in overall investments in Morocco's 12 administrative regions to increase the stock and quality of infrastructure across sectors; however, the exact remit of regional entities and the approaches to financing are yet to be defined. As regions become

52 Lifecycle costing refers to the cost-effectiveness of competing alternatives when considering all costs incurred over the life of an asset 
increasingly responsible for infrastructure investment, it is important to identify potential mismatches between their investment mandates and financial resources, and to ensure that there are adequate financial and human resources at the regional level to support project preparation, evaluation and implementation.

\subsection{Conclusion}

This chapter presented a scenario analysis showing that continued investment in infrastructure, both in terms of asset development and asset maintenance, is critical to ensure continued economic growth while addressing regional disparities. The changing macroeconomic context - and the growing public debt - is starting to impose a limit on how much the government can continue to finance infrastructure from public sources, requiring increased attention to value for money, efficiency of public enterprises, sustainability and cost recovery. The development of PPPs can bring operational efficiency, technology and mobilization of resources, which will reduce the calls on government resources and guarantees. The next chapter will present elements of a reform agenda that could help the country meet its future infrastructure needs despite a tighter fiscal context. 


\section{Chapter 4. Toward an Action Plan}

The previous chapters concluded that Morocco has made impressive progress in developing its infrastructure, and that large investments in infrastructure have contributed in a significant way to growth and poverty alleviation. It also shows that Morocco's infrastructure sector faces a number of challenges that have constrained the impact of these investments and increased the reliance on fiscal support. Maintaining the momentum of investments will be harder to achieve in a more constrained fiscal environment. In order to meet this challenge, the report proposes to focus on four major areas for action: (i) improving the planning and socio-economic impact of infrastructure investments, (ii) enhancing cost recovery and improving the management of fiscal impact; (iii) improving the efficiency of SOEs in carrying out their mandates, and; (iv) leveraging PPPs and domestic financing to supplement government funding and guarantees. These actions are not sequential and may be carried out in parallel. Sector specific recommendations and selected projects in the infrastructure pipeline are presented in Appendix B.

\section{A. Improving the planning and impact of infrastructure investments}

\section{Deploy a stronger public investment management (PIM) framework}

A PIM framework is being finalized by the Directorate of Budget under the MEF. Applied systematically, it would enable prioritizing investment projects and improving social impacts by:

(i) Development of a legal framework to strengthen and coordinate subsector planning. This includes the adoption and implementation of the Organic Law for Public Financing and development of a unified framework for preparing and managing investment projects. Development of an integrated project management system and database for investment projects, and preparation of process manuals and guidelines for evaluating and managing public investment projects.

The application of relevant aspects of the PIM framework should be specifically adopted by public agencies responsible for investment in each infrastructure sub-sector. Investment plans should include an explicit assessment of the financial and economic costs and benefits of the proposed infrastructure projects, as well as options scenarios for alternative investments and the costs of inaction. An assessment of project bankability and potential sources of finance should be carried out following common evaluation guidelines for all subsectors. Procurement and contracting systems should be upgraded to improve value for money in public procurement, and the effects monitored to assess their impact on outcomes. Additionally, inefficiencies within the infrastructure supply chain should be addressed to reduce the overall construction cost (see Box 4.1).

\section{Box 4.1: Construction Costs}

Inefficiencies within the construction industry contribute to higher spending on infrastructure. Specifically, high construction costs result from two sources: inputs, such as cement and steel; and, services, such as those provided by construction and engineering firms. The higher costs are a result of weaknesses in market structure and public policy that prevent the industry from being competitive. For example, the United Kingdom has in recent years adopted a national strategy of digitalization of the construction industry known as building information modelling (BIM). Thanks to the ensuing increase in both transparency and efficiency, it saw a reduction in the cost of public works by some 15 percent. A deeper analysis of the infrastructure supply chain in Morocco is needed to identify inefficiencies that could contribute to reduced costs if addressed. 


\section{B. Enhancing cost recovery and improving the management of fiscal impact}

\section{Adopt quantitative techniques for performance benchmarking}

Quantitative efficiency benchmarking will be key to organize the regulatory process and would signal the country's commitment to competitiveness in its infrastructure activities. It would also identify opportunities to reduce cost through improvements in operating efficiency and investments. This would include tracking the cost of capital and asset values, as well as assessing the drivers of the rate of return, of the level and quality of services, and of investment commitments made in contracts between the state and operators. These tools are useful whether the operators are public or private and will improve the transparency of decisions. Effective, fair, and transparent economic regulation is a key factor in the assessment of risk by creditors. Most importantly, benchmarking would incentivize service providers to increase capacity and efficiency.

\section{Develop rigorous methodology for tariff setting and monitoring of fiscal impact}

Better pricing of services (in terms of affordability, tariff structure and periodic reviews) should play an increasing role in the financial and social sustainability of projects. This requires establishing tariffs on sound methodologies, while accounting for transfers and taxes in the financing mix. The establishment of the unique social register and biometric system will help to target direct subsidies to households or, failing that, provide tariff advantages for these beneficiaries.

When enhanced cost recovery threatens to make services unaffordable for certain user groups, and when subsidies are not an option, it would be desirable to sharpen price discrimination. Price discrimination could introduce new tariff levels and structures for various levels of consumption. If well-regulated, such structures would signal to the market that the country is committed to ensuring adequate revenue while protecting vulnerable consumers and allowing operators to achieve a fair rate of return.

\section{Improving the efficiency of the SOEs}

\section{Rationalize the mandates of public stakeholders}

SOEs will continue to play a critical role in infrastructure services delivery for the foreseeable future. One of the most pressing institutional needs is to carry out a detailed inventory of the infrastructure mandates of public sector stakeholders at all levels of government to reveal overlaps, omissions, and inconsistencies. Such an inventory would make it possible to simplify the organization of each subsector, reduce coordination challenges, and facilitate the provision of institutional support for infrastructure services delivery. In the context of the impending decentralization, it is necessary to map the roles and responsibilities of agencies in the infrastructure sectors to avoid overlap and ensure controls and adequate balances.

\section{Apply the existing code of good corporate governance practices to all infrastructure SOEs}

The annex of SOEs under the governance code was promulgated in 2012. The main recommendations of the code are developed across the following main points: clarifying the relation between the state and the SOEs; the role and responsibilities of the governing bodies (SOEs administrative councils or boards); shareholder rights and their equitable treatment; transparency and dissemination of information; and, improving relations with stakeholders, including consumers, suppliers and financiers.

Around twenty SOEs have adopted the code so far, including a few from infrastructure sectors. Implementing the recommendations could contribute to improving governance of SOEs, for instance by integrating independent administrative members to the governing bodies (administrative councils or boards), developing internal regulations, creating specialized committees, developing a governance 
charter, a dividend policy and disseminating information on the performance of management and operations in a transparent manner. The partial listing of financially viable public companies could also improve their governance, transparency and efficiency, while mobilizing additional capital.

\section{Accelerate SOE reforms to improve their efficiency}

Many SOEs have respectable technical capabilities, but their level of financial indebtedness and reliance on Treasury guarantees is a source of concern. Working with supervisory authorities, each SOE should accelerate measures already initiated and aimed at increasing efficiency in the delivery of services and strengthening their capacity to carry out new investments.

\section{Review of the contrats programmes to regulate the performance of SOEs against targets}

Regulation can either be done by contract or through independent regulatory agencies, with the principle aim of objectively setting tariffs and performance benchmarks. Independent regulation becomes more relevant in sectors where there are a number of service providers and there is a need for a national regulator to license providers, monitor performance standards and enforce compliance. Morocco has opted to regulate infrastructure sectors by contract (contrats programmes) between the state and SOEs. Under this model, it is also important to have independent monitoring of contract implementation and the performance of the service providers, in addition to the controls already applied by the state.

Timely and realistic contrats programmes can help SOEs clarify their objectives, investment plans, and mutual obligations of the state and the enterprise in meeting targets. These instruments can also help access market finance, as the key issue for private lenders is the reliability of cash flows. For example, a subsidy regime agreed through the contrats-programmes could enhance confidence in sustainability of SOE operations needed by commercial lenders to increase their exposure.

\section{Leveraging PPPs and mobilizing financing without state guarantees}

Morocco already has experience in PPPs and can increase their role in developing and managing infrastructure. This would require more effective organization and origination of these projects, and a focus on bankability.

\section{Originating PPP projects}

Effective origination of PPP projects requires organization and coordination between different stakeholders, a high level of technical and commercial expertise at national and regional agencies responsible for PPP development, and sufficient funds to cover preparation costs.

International experience shows that it is important that line ministries and implementing agencies retain responsibility for the development of PPP projects in their respective sectors, and that they are signatories to contracts with the private parties. The level of experience with PPP transactions in Morocco varies between sectors, ministries and agencies. Certain sectors, such as water, energy, transport and ports have considerable experience and technical and institutional capacity to develop PPPs. That said, developing PPPs will require further technical support and transaction level advice to prioritize, evaluate, structure, and negotiate projects, and evaluate them after completion. This external expertise represents a significant cost, and so, Morocco could consider establishing a project development fund to finance the following categories of expenditure related to PPPs:

i) Institutional development of the PIM-PPP framework: technical assistance, reinforcing capacity at contracting agencies, socio-economic and cost-benefit studies, etc;

ii) Upstream management of PPP projects: strategic advice, pre-feasibility studies etc; 
iii) Downstream activities required to bring mature projects to market: detailed feasibility studies detailed; contractual and financial structuring, preparation of tenders, transactional advice etc. until the signing of project contracts and financing agreements;

iv) After contract signature, monitoring during the construction and implementation period, and where necessary, external advice for restructuring.

\section{Bankability of PPP projects}

PPP transactions generally fall into one of the following three categories:

i) Projects with high socio-economic benefits and which are commercially viable as a result of tariffs charged to consumers;

ii) Projects with high socio-economic benefits but which do not generate sufficient commercial revenues and hence rely government budget support to cover costs; and,

iii) Efficiency improvement or cost reduction projects (which may only require low investment)

Projects falling under the first category include: ports and airports with high commercial traffic; solar and wind energy generation; desalination and reuse of wastewater; irrigation for commercial-scale agriculture; and, ICT-related investments, such as broadband, network expansion and submarine cables. The "bankability" of PPP projects in the second category can be strengthened through the use of a viability gap fund, and additional compensation for projects offering high socioeconomic benefit but with insufficient revenues to satisfy commercial investors.

PPPs can improve the efficiency of infrastructure provision through enhanced quality of service, new technologies and the possibility of lower costs, especially when there is sufficient competition in the in the tendering phase; however, it is important to monitor and regulate the obligations of private providers to realize these potential benefits. And where the cost of services increases, targeted subsidies to households may be necessary to protect the most vulnerable segments of the population.

\section{Build the capacity of SOEs to raise financing without state guarantees and develop bond markets.}

Infrastructure SOEs benefit from state budget support in at least two ways. So far, infrastructure SOE loans from external creditors, and to a certain extent domestic creditors, have been supported with guarantees from the national Treasury. Furthermore, reimbursement of SOE loans is assured, at least in part, through the national budget, for example through operating subsidies if the gross operating surplus generated from user fees is insufficient to cover the entire debt service. Hence the objective should be to increasingly strengthen the capacity of SOEs to borrow with less support from government guarantees, and ultimately, to service their debt with minimum recourse to the national budget. The contrats programme can help achieve this objective. In certain cases, public enterprises could consider splitting some of their activities into two types of businesses from a financial perspective-a commercial business producing the cash flow required for private commercial debt and a strictly public business that must continue to depend on subsidies or guarantees.

Subject to establishing their repayment capacity to meet the criteria of financial investors, SOEs could access new local financing sources, including infrastructure project bonds. These bonds could refinance bank loans once projects reach the commercial operation phase. To develop (public or private) corporate bonds in Morocco, it would be useful to further develop the credit culture, so that the pricing of securities reflects their relative credit risk. This could be supported by the establishment of a local credit rating agency. Prudential requirements may also need to be revisited, so that asset allocation more systematically takes into account the credit risk associated with different types of securities. The use of international financing may also prove useful on a case-by-case basis if the (long) duration and rates are attractive, although exchange rate risk remains a handicap for this type of financing. 


\section{E. Infrastructure sub-sector priorities}

In addition to the cross-cutting actions outlined above, there are several important measures to be taken at the infrastructure sub-sector level. The highlights are presented here, and further details of sub-sector specific recommendations and selected projects in the infrastructure pipeline are presented in Appendix B.

Water and sanitation: Proposed areas of reform consist of updating the institutional and regulatory framework, strengthening the viability of sector agencies, and improving the management of water resources and reuse of wastewater. Envisaged measures: improving sector data and planning; establishing a water information system for collecting, processing and disseminating sectoral data, for example, through a national observatory; developing guidelines to implement the 2016 water $1 \mathrm{w}^{53}$, considering mechanisms to facilitate the development of desalination, valuation and reuse of wastewater, while strengthening integrated water resources management systems; establishing performance and investment objectives when finalizing the contrat programme between the state and ONEE; addressing rural water and sanitation access gaps through further investment in rural areas; diversifying water resources, including through desalination and wastewater reuse; addressing the financial sustainability of the sector by reviewing tariffs along the entire water chain, as well as other sources of funding such as taxes and transfers; and reforming the regional agricultural development offices.

Transport: Proposed areas of reform are strengthening the regulatory framework, particularly with regards to the participation of the private sector, and improving the viability of SOEs in the transport sector. Envisaged measures: Continuing to increase the operational efficiency of ONCF and considering opening parts of the of the company's operations to private sector participation; reviewing options for increased private sector participation in the ports and airports sub-sectors; continuing to improve the financial viability of AdM and ONCF, and the financial sustainability of the urban transport sector through a review of tariffs and cost structures; and, sustaining the financial viability of the ports authorities and entities (ANP, TMSA, and SODEP Marsa Maroc), as well as that of ONDA.

Electricity: Envisaged areas of reform concern the liberalization of the renewable energy sector, operationalizing energy efficiency, as well as the continued evolution of the sector institutional framework. Envisaged measures: Operationalizing the independent regulatory authority, the Autorité Nationale de Régulation de l'Eléctricité (ANRE), to stimulate investment in renewables and regulate private energy companies; improve the operating efficiency of the sector by rationalizing the roles of sector agencies to clarify responsibilities and avoid overlap ${ }^{54}$; pursuing reforms to stimulate private investment in the small and medium size renewable energy market; and, operationalizing the energy efficiency law in order to realize energy savings

ICT: Envisaged measures: Strengthening the national policy framework to stimulate investment, including formal adoption of the national digital economy strategy and the note on sector strategic orientation 2019-2024; strengthening competition by permitting new private players to invest in broadband infrastructure; using the Universal Service Fund to attract private investment in broadband infrastructure in underserved areas; optimizing the use of existing digital infrastructures owned by SOEs; and stimulating the demand for broadband by improving consumer readiness and increasing the availability of relevant local content.

\footnotetext{
53 Law No. 36-15, promulgated by Dahir No. 1-16-113 of August 10, 2016 on water

${ }^{54}$ The new Bill 13-09 should improve the situation in the area of renewable energy
} 


\section{Appendix A. Key Sector Indicators}

\section{Water sector}

\begin{tabular}{|c|c|c|}
\hline Country context & 2011 & 2017 \\
\hline Infant mortality (Per '000 live births) & 27.8 & $24(2015)$ \\
\hline \multicolumn{3}{|l|}{ Sector structure } \\
\hline Agricultural irrigated land (\% of total agricultural land) & 4.3 & $4.6(2011)$ \\
\hline $\begin{array}{l}\text { Annual freshwater withdrawals, agriculture (\% of total freshwater } \\
\text { withdrawal) }\end{array}$ & & $88(2015)$ \\
\hline Improved sanitation facilities (\% of the population with access) & 83 & 89 \\
\hline Improved sanitation facilities, rural (\% of rural population with access) & 69 & 79 \\
\hline Improved sanitation facilities, urban (\% of urban population with access) & 92 & 94 \\
\hline Improved water source (\% of population with access) & 79 & $\begin{array}{c}87 \text { (WDI)/ } 97 \\
(\mathrm{ONEE} / \mathrm{HCP}) \\
(2015) \\
\end{array}$ \\
\hline Improved water source, rural (\% of rural population with access) & 56 & $\begin{array}{c}71(\mathrm{WDI}) / 97 \\
(\mathrm{ONEE} / \mathrm{HCP}) \\
(2015)\end{array}$ \\
\hline Improved water source, urban (\% of urban population with access) & 95 & 97 \\
\hline People practicing open defecation (\% of population) & 18 & 7 \\
\hline People practicing open defecation, rural (\% of rural population) & 39 & 19 \\
\hline People practicing open defecation, urban (\% of urban population) & 1 & 0 \\
\hline $\begin{array}{l}\text { Water productivity, total (constant } 2010 \text { \$ GDP per cubic meter of total } \\
\text { freshwater withdrawal) }\end{array}$ & & $10(2015)$ \\
\hline \multicolumn{3}{|l|}{ Extent of PSP $(\%)$} \\
\hline \multicolumn{3}{|l|}{ Access } \\
\hline \multicolumn{3}{|l|}{ Household with access to: } \\
\hline Water connection (piped onto premises) (\%) & 65 & 70 \\
\hline Sewerage connection $(\%)$ & 52 & 56 \\
\hline \multicolumn{3}{|l|}{ Urban households with access to: } \\
\hline Water connection (piped onto premises) (\%) & 88 & 89 \\
\hline Sewerage connection $(\%)$ & 86 & 88 \\
\hline \multicolumn{3}{|l|}{ Rural households with access to: } \\
\hline Water connection (piped onto premises) (\%) & 33 & 40 \\
\hline Sewerage connection $(\%)$ & 3 & 3 \\
\hline \multicolumn{3}{|l|}{ Average water connection charge $(\$)$} \\
\hline \multicolumn{3}{|l|}{ Average sewerage connection charge (\$) } \\
\hline \multicolumn{3}{|l|}{ Average time to water source (mins) } \\
\hline \multicolumn{3}{|l|}{ Affordability } \\
\hline Average tariff $\left(\$ / \mathrm{m}^{3}\right)$ for $15 \mathrm{~m}^{3} / \mathrm{month}$ & & $0.73(2016)$ \\
\hline Average water consumption ( $\mathrm{m}^{3} /$ month) & 2.55 & \\
\hline
\end{tabular}

Source: authors' compilation based on various sources and exchanges with key sector stakeholders.

Note: GDP = gross domestic product; $\mathrm{m}^{3}=$ cubic meter; WDI = World Development Indicators; $\mathrm{HCP}=$ High Commissioner for Planning 


\section{Transport sector}

\begin{tabular}{|c|c|c|}
\hline Country context & 2011 & 2016 \\
\hline Air transport, freight (million ton-km) & 41 & $74(2017)$ \\
\hline Air transport, passengers carried (WDI) ${ }^{55}$ & $3,492,984(2005)$ & $8,436,970$ \\
\hline Air transport, registered carrier departures worldwide & $48,651(2005)$ & $80,085(2014)$ \\
\hline $\begin{array}{l}\text { Quality of port infrastructure, WEF }(1=\text { extremely underdeveloped to } 7= \\
\text { well developed and efficient by international standards) }\end{array}$ & $4.1(2005)$ & $5.0(2017)$ \\
\hline Rail lines (total route-km) & $1,907(2005)$ & 2,109 \\
\hline Railways, goods transported (million ton-km) & $5,919(2005)$ & $4,749(2015)$ \\
\hline Railways, passengers carried (million passenger-km) & 2,987 (2005) & 5,208 \\
\hline \multicolumn{3}{|l|}{ Sector structure } \\
\hline Length of road network $(\mathrm{km})$ & $58,698(2011)$ & 57,334 \\
\hline Length of paved road network $(\mathrm{km})$ & $41,105(2012)$ & 43,318 \\
\hline Primary (national) & $9,816(2012)$ & 10,203 \\
\hline Secondary (regional) & $9,221(2012)$ & 9,370 \\
\hline Tertiary (provincial) & $22,068(2012)$ & 23,745 \\
\hline Traffic (vehicle km per day) & 80 million (2011) & 99.35 million \\
\hline Primary (national) & & 42.39 million \\
\hline Secondary (regional) & & 19.22 million \\
\hline Tertiary (provincial) & & 16.39 million \\
\hline Highways & $\begin{array}{l}18.01 \text { million } \\
(2012)\end{array}$ & 21.34 million \\
\hline \multicolumn{3}{|l|}{ Length of primary network (national) $(\%)$} \\
\hline$<750$ vehicles per day $(\%)$ & $20.9(2011)$ & 20.57 \\
\hline$>4,500$ vehicles per day $(\%)$ & $35(2011)$ & 32.35 \\
\hline \multicolumn{3}{|l|}{$\begin{array}{c}\text { Access } \\
\end{array}$} \\
\hline Access to all-weather road by rural population (\%) & $74(2012)$ & 80 \\
\hline \multicolumn{3}{|l|}{\begin{tabular}{|c|} 
Affordability \\
\end{tabular}} \\
\hline Transport expenditure—national (\% income) & $8.8(2007)$ & $7.1(2014)$ \\
\hline Urban (\% income) & $9.6(2007)$ & $7.4(2014)$ \\
\hline Rural (\% income) & $7.2(2007)$ & $6.5(2014)$ \\
\hline Subsistence expenditure-national (\% income) & $40.6(2007)$ & $37(2014)$ \\
\hline \multicolumn{3}{|l|}{$\begin{array}{c}\text { Quality } \\
\end{array}$} \\
\hline Paved road in good to average condition (\%) & $53.4(2012)$ & 60 \\
\hline \multicolumn{3}{|l|}{$\begin{array}{ll} & \text { Sustainability } \\
\end{array}$} \\
\hline Public expenditure on roads $(\$ / \mathrm{km})$ & & 179,270 \\
\hline
\end{tabular}

Source: authors' compilation based on various sources and exchanges with key sector stakeholders.

Note: $\mathrm{km}^{2}=$ square kilometers; WDI = World Development Indicators

55 ONDA reported 9,192,770 of air passengers transported in 2005 and 18,257,851 in 2016 based on a different estimation methodology. 


\section{Energy sector}

\begin{tabular}{|c|c|c|}
\hline $\begin{array}{l}\text { Country context } \\
\end{array}$ & 2012 & 2014 \\
\hline Final energy consumption (Tcal ‘000’s) & 0 & 190.7 \\
\hline Energy consumption per capita (Gcal) & 5.4 & 5.6 \\
\hline Energy intensity of GDP (kgoe/\$2011 PPP GDP) & 0.08 & 0.08 \\
\hline Electricity consumption $(\mathrm{GWh})$ & 26,806 & 27,924 \\
\hline Natural gas consumption $\left(\right.$ million $\left.\mathrm{m}^{3}\right)$ & 1,177 & 1,108 \\
\hline Electricity consumption per capita $(\mathrm{kWh})$ & 810 & 825 \\
\hline Access to clean fuels and technologies for cooking (\% of population) & 94 & 99 \\
\hline Access to electricity, rural (\% of rural population) & $97.4(2011)$ & $99.53(2017)$ \\
\hline Access to electricity, urban (\% of urban population) & $97.7(2011)$ & $100(2017)$ \\
\hline Electric power transmission and distribution losses (\% of output) & $10.693(2011)$ & 15 \\
\hline Electricity production from hydroelectric sources (\% of total) & $8(2011)$ & 6 \\
\hline Electricity production from natural gas sources (\% of total) & $16.2(2011)$ & 20 \\
\hline Electricity production from oil sources (\% of total) & $26.3(2011)$ & 13 \\
\hline Electricity production from oil, gas, and coal sources (\% of total) & $89.211(2011)$ & 88 \\
\hline $\begin{array}{l}\text { Electricity production from renewable sources, excluding hydroelectric (\% of } \\
\text { total) }\end{array}$ & $2.767(2011)$ & 7 \\
\hline $\begin{array}{l}\text { Electricity production from renewable sources, excluding hydroelectric } \\
\text { (MWh) }\end{array}$ & $692,000(2011)$ & $1,924,000$ \\
\hline \multicolumn{3}{|l|}{ Sector structure } \\
\hline \multicolumn{3}{|l|}{ Number of players } \\
\hline Electricity generation & 4 & 5 \\
\hline Electricity transmission & 1 & 1 \\
\hline Electricity distribution & 12 & 12 \\
\hline \multicolumn{3}{|l|}{ Private sector participation $(\%)$} \\
\hline Electricity generation (in terms of energy GWh) & $12,619.9(2011)$ & $20,153.1(2016)$ \\
\hline Electricity capacity (in terms of capacity MW) & 6,377 & \\
\hline Electricity transmission & 0 & 0 \\
\hline Electricity distribution (in terms of energy sales in GWh) & $6,852.5(2011)$ & $7,667.7(2015)$ \\
\hline Electricity distribution (in terms of clients) & $1,836,274(2011)$ & $2,107,623(2015)$ \\
\hline \multicolumn{3}{|l|}{ Number of players } \\
\hline Gas transportation & 0 & 0 \\
\hline LPG distribution & 0 & 0 \\
\hline \multicolumn{3}{|l|}{ Extent of PSP $(\%)$} \\
\hline Gas transportation & 100 & 100 \\
\hline LPG distribution & 100 & 100 \\
\hline \multicolumn{3}{|l|}{ Access } \\
\hline \multicolumn{3}{|l|}{ Access to electricity (\%) } \\
\hline Urban & 100 & 100 \\
\hline Rural & 98.06 & 98.95 \\
\hline Total & 99 & 100 \\
\hline \multicolumn{3}{|l|}{ Access to modern fuels (\%) } \\
\hline Urban & 100 & 100 \\
\hline Rural & 100 & 100 \\
\hline Total & 100 & 100 \\
\hline \multicolumn{3}{|l|}{ Access to natural gas (\%) } \\
\hline In proximity to distribution network & 0 & 0 \\
\hline Among total urban population & 0 & 0 \\
\hline Among total population & 0 & 0 \\
\hline Access to LPG $(\%)$ & 100 & 100 \\
\hline \multicolumn{3}{|l|}{ Affordability } \\
\hline \multicolumn{3}{|l|}{ Average electricity tariff $(\mathrm{cDH} / \mathrm{kWh})$ of ONEE } \\
\hline \multicolumn{3}{|l|}{ Residential-Urban } \\
\hline 1 to $200 \mathrm{kWh}(\mathrm{cDH} / \mathrm{kWh})$ & & $6(2016)$ \\
\hline 201 to $350 \mathrm{kWh}(\mathrm{cDH} / \mathrm{kWh})$ & & $9(2016)$ \\
\hline 351 to $700 \mathrm{kWh}(\mathrm{cDH} / \mathrm{kWh})$ & & $12(2016)$ \\
\hline More than $701 \mathrm{kWh}(\mathrm{cDH} / \mathrm{kWh})$ & & $19(2016)$ \\
\hline \multicolumn{3}{|l|}{ Rural } \\
\hline 1 to $100 \mathrm{kWh}(\mathrm{cDH} / \mathrm{kWh})$ & & $9(2016)$ \\
\hline More than $101 \mathrm{kWh}(\mathrm{cDH} / \mathrm{kWh})$ & & $19(2016)$ \\
\hline Commercial & & \\
\hline
\end{tabular}




\begin{tabular}{|c|c|c|}
\hline Small (cDH/kWh) & & 22 or $25(2016)$ \\
\hline Large (cDH/kWh) & & $30(2016)$ \\
\hline \multicolumn{3}{|l|}{ Industrial } \\
\hline Small (cDH/kWh) & & $22(2016)$ \\
\hline Large $(\mathrm{cDH} / \mathrm{kWh})$ & & $35(2016)$ \\
\hline \multicolumn{3}{|l|}{$\begin{array}{ll}\text { Efficiency } \\
\end{array}$} \\
\hline \multicolumn{3}{|l|}{ Electricity distribution performance (ONEE) } \\
\hline Distribution losses (\%) & 10.4 & 10.5 \\
\hline Workers per 1,000 connections & 1.42 & 1.33 \\
\hline \multicolumn{3}{|l|}{ Delay in payment (days) } \\
\hline \multicolumn{3}{|l|}{ Amount billed (million DH) } \\
\hline Amount collected from energy sales (million DH) & $22,366(2011)$ & $29,680(2016)$ \\
\hline \multicolumn{3}{|l|}{ Collection rate $(\%)$} \\
\hline \multicolumn{3}{|l|}{ Quality } \\
\hline \multicolumn{3}{|l|}{ Quality of electricity service } \\
\hline Hours of service per day & 24 & 24 \\
\hline Interruptions per month & 0.31 & 0.26 \\
\hline Hours of interruption per month & Oh $19 \mathrm{~m} \mathrm{10s}$ & Oh $17 \mathrm{~m}$ \\
\hline \multicolumn{3}{|l|}{ Sustainability } \\
\hline Public investments (million DH) & $5,818(2011)$ & $6,002(2016)$ \\
\hline Future public investment plans (million DH) & & $\begin{array}{c}115,000 \text { budgeted } \\
\text { between } 2016 \text { and } \\
2020\end{array}$ \\
\hline Generation plants to be constructed (MW) & & $\begin{array}{c}1,186.5 \text { MW } \\
\text { ONEE and 4,446 } \\
\text { MW IPPs between } \\
2017 \text { and } 2020\end{array}$ \\
\hline
\end{tabular}

Source: authors' compilation based on various sources and exchanges with key sector stakeholders.

Note: $\mathrm{cDH}=$ cents of $\mathrm{DH} ; \mathrm{DH}=$ Moroccan dirham; $\mathrm{Gcal}=$ gigacalorie $; \mathrm{GDP}=$ gross domestic product GWh = gigawatthour; IPP = independent kgoe = kilogram of oil equivalent; $\mathrm{kWh}=$ kilowatt-hour; $\mathrm{LPG}=$ liquid petroleum gas; $\mathrm{m}^{3}=$ cubic meter; $\mathrm{MW}=$ megawatt; $\mathrm{MWh}=$ megawatt-hour; ONEE = Office National de l'Electricité et de l'Eau Potable; $\mathrm{PPP}=$ purchasing power parity; $\mathrm{PSP}=$ private sector participation; $\mathrm{Tcal}=$ teracalorie . 


\section{Information and communication technology (ICT) sector}

\begin{tabular}{|c|c|c|}
\hline $\begin{array}{c}\text { Context } \\
\end{array}$ & 2010 & 2015 \\
\hline \multicolumn{3}{|l|}{ Long distance traffic (minutes/subscription/month) } \\
\hline National & 35.9 & 89.6 \\
\hline International & 52 & 57.1 \\
\hline \multicolumn{3}{|l|}{ International voice traffic } \\
\hline \multicolumn{3}{|l|}{ Sector structure } \\
\hline Number of players & 3 & 3 \\
\hline Local telephony providers & 3 & 3 \\
\hline Long-distance providers & 3 & 3 \\
\hline Cellular telephony providers & 3 & 3 \\
\hline Internet service providers (ISPs) & 3 & 3 \\
\hline Number of ISPs independent from the licensed telecom operators & 0 & 0 \\
\hline $\begin{array}{l}\text { Number of facility-based ISPs independent from the licensed telecom } \\
\text { operators }\end{array}$ & 0 & 0 \\
\hline Number of wholesale operators & 0 & 0 \\
\hline Number of mobile virtual network operators (MVNOs) & 0 & 0 \\
\hline Separate telecommunications/ICT regulator & Yes & Yes \\
\hline Status of main fixed-line telephone operator & Mixed & Mixed \\
\hline \multicolumn{3}{|l|}{ Level of competition (competition, partial competition, monopoly) } \\
\hline International gateway(s) & Competition & Competition \\
\hline Mobile telephone service & Competition & Competition \\
\hline Internet service providers & Competition & Competition \\
\hline Foreign ownership (not allowed, restricted, allowed) & Allowed & Allowed \\
\hline $\begin{array}{l}\text { Regular treatment of voice over internet protocol (VoIP) (banned, closed to, } \\
\text { no framework, allowed) }\end{array}$ & Closed & Banned \\
\hline Existence of a regulation council within the regulatory authority (Yes/No) & No & No \\
\hline \multicolumn{3}{|l|}{ Access } \\
\hline \multicolumn{3}{|l|}{ Teledensity (per 100 inhabitants) } \\
\hline \multicolumn{3}{|l|}{ Telephones } \\
\hline Fixed-telephone subscriptions & 11.8 & 6.5 \\
\hline Mobile-cellular telephone subscriptions & 101.1 & $123(2017)$ \\
\hline \multicolumn{3}{|l|}{ Fixed lines outside larger cities } \\
\hline Fixed-broadband subscriptions & 1.6 & 3.4 \\
\hline Mobile-broadband subscriptions & 0.6 & 23 \\
\hline Individuals using the Internet (\%) & 52 & $61.7(2017)$ \\
\hline Households with Internet & 26 & 67 \\
\hline \multicolumn{3}{|l|}{ Ownership (\% of households) } \\
\hline Computer & 34.2 & 54.8 \\
\hline Internet access at home & 25.5 & 66.5 \\
\hline Telephone mobile & 83 & 94 \\
\hline \multicolumn{3}{|l|}{ Urban ownership (\% of households) } \\
\hline Computer & 59 & 69 \\
\hline Internet access at home & 51 & 76 \\
\hline Telephone mobile & 96 & 97 \\
\hline \multicolumn{3}{|l|}{ Rural ownership (\% of households) } \\
\hline Computer & 22 & 26 \\
\hline Internet access at home & 16 & 47 \\
\hline Telephone mobile & 86 & 89 \\
\hline \multicolumn{3}{|l|}{ Affordability } \\
\hline \multicolumn{3}{|l|}{ Fixed-telephone subbasket (\$ a month) } \\
\hline Mobile-cellular subbasket (\$ a month) & 33.1 & 10.2 \\
\hline Fixed-broadband subbasket (\$ a month) & 11.7 & 10.1 \\
\hline Mobile-broadband, prepaid handset-based, 500 megabytes (MB) (\$ a month) & 46.4 & 5.1 \\
\hline Mobile-broadband, postpaid computer-based, 1 gigabyte (GB) (\$ a month) & 11.5 & 10.1 \\
\hline \multicolumn{3}{|l|}{ Cost of a three-minute call (\$) } \\
\hline Long distance national & 0.38 & 0.30 \\
\hline \multicolumn{3}{|l|}{ Long distance international } \\
\hline Cellular telephony & 0.43 & 0.09 \\
\hline \multicolumn{3}{|l|}{ Cost of monthly subscription $(\$)$} \\
\hline Fixed line & & \\
\hline
\end{tabular}




\begin{tabular}{|c|c|c|}
\hline \multicolumn{3}{|l|}{ Mobile line } \\
\hline Internet service provider & 17.6 & 10.4 \\
\hline \multicolumn{3}{|l|}{ Efficiency } \\
\hline Telecommunications revenue (\% GDP) & 4.6 & 3.5 \\
\hline Telecommunications investment (\% of revenue) & 17.0 & 19.9 \\
\hline Private investment in telecom infrastructure $(\$)$ & $1,980,000,000$ & $800,000,000$ \\
\hline \multicolumn{3}{|l|}{ Kilometers of fiber-optic infrastructure built by telecom operators } \\
\hline Maroc Telecom & & 25,000 \\
\hline Orange/Meditel & & 3,400 \\
\hline Wana/Inwi & & 2,100 \\
\hline \multicolumn{3}{|l|}{$\begin{array}{l}\text { Kilometers of fiber-optic infrastructure built by utility companies (other than } \\
\text { telecom operators) }\end{array}$} \\
\hline Office National des Chemins de Fer (ONCF) & & 1,600 \\
\hline Office National de l'Electricité et de l'Eau Potable (ONEE) & & 7,000 \\
\hline Autoroutes du Maroc (ADM) & & 2,050 \\
\hline Number of fiber-optic submarine cables & & 4 \\
\hline \multicolumn{3}{|l|}{ Sustainability } \\
\hline Population covered by at least a $2 \mathrm{G}$ mobile network (\%) & 98 & 99 \\
\hline Population covered by at least a 3G mobile network (\%) & 69 & 80 \\
\hline Population covered by at least an LTE/WIMAX mobile network (\%) & & 45 \\
\hline International Internet bandwidth (bit/s per Internet user) & 4,558 & 18,316 \\
\hline Household with Internet equipment in urban areas (\%) & 51 & 76 \\
\hline Household with Internet equipment in rural areas (\%) & 16 & 47 \\
\hline
\end{tabular}

Household with Internet equipment in rural areas (\%) Source: authors' compilation based on various sources and exchanges with key sector stakeholders Note: $2 \mathrm{G}=$ second-generation cellular technology; $3 \mathrm{G}=$ third-generation cellular technology; LTE = long-term evolution; WIMAX = Worldwide Interoperability for Microwave Access. 


\section{Appendix B. Sub-sector specific recommendations and investment project pipeline}

\section{Water and sanitation}

This section presents a number of short- and medium- to long-term measures in the water and sanitation sector that could help attract private investment and commercial financing, as well as better manage costs. A list of potential investment opportunities is also presented.

\section{Short-term measures}

\section{a) Develop implementing guidelines under the water law}

Law 36/15, enacted in October 2016 but pending implementation, aims to clarify the water sector legal framework, which would help in attracting private investment into the sector. The implementing regulations are expected to contain provisions that would assist the development of desalination and water reuse - through PPPs, the creation of river basin committees, and strengthening the involvement of water users' associations in the management of groundwater resources through framework conventions (contrats de nappes). Article 88 refers to the creation of Hydraulic Basin Councils, which would be in charge of examining and providing advice on planning matters.

\section{b) Adoption of the national plan for water and sanitation}

In 2005, Morocco launched an ambitious national sanitation plan to connect 80 percent of the population in urban areas to the sewer network by 2020 , and to ensure that 60 percent of wastewater is treated. By 2016, the sewer connection rate in urban areas was 73 percent and the wastewater treatment rate was 36 percent, compared with just 8 percent at the start of the plan. With increasing demand from rural populations for household water connections, the urgency of providing appropriate sanitation solutions is rising. ONEE does not have a clear mandate to provide sanitation services in rural areas and it seems that in the current situation, it will not take in charge that service in those areas. Therefore, until institutional responsibilities are clarified, the prospects of boosting access to clean and affordable sanitation facilities and services are slim. Part of the challenge is to define clear funding sources for rural sanitation infrastructure and services, probably through a combination of budgetary allocations, end-user fees, and concessional financing. A national framework for wastewater reuse is also lacking, although the government is currently finalizing a new plan to address holistically the issues of urban sanitation, rural sanitation and wastewater reuse. There may be PPP opportunities in these areas.

\section{c) Finalize the contrat programme between the state and ONEE}

ONEE's most recent contrat programme was for the period 2014-17, and while it was extended for an additional year, it is anticipated that a new contract should start in December 2019. This provides an opportunity for a clear discussion between the state and ONEE on funding, tariffs, and reforms for ONEE to improve its financial situation, particularly with regards to its water and sanitation business, and the role of increased private sector participation in its activities.

\section{d) Improve sector data and planning}

In general, sector information could be better centralized to allow performance evaluation and serve as the basis for better planning. One option is to set up a national observatory to centralize data in the sector, which would allow, among other things, a better forecast of water supply and demand according to dynamic land use planning (such as the basins located east of the Atlas mountains where population growth is out of step with the available water resources). 
In terms of planning, the items stipulated in the National Water Plan should be more systematically taken into account in accordance with the provisions of the water law and regional development programs.

\section{e) Mobilize private sector solutions}

Based on lessons learned from recent pilots, such as the output-based aid approach in Jorf El Melha, there may be opportunities to involve private operators and mobilize private finance through blending with concessional sources.

\section{Medium-to-long-term measures}

\section{a) Review tariffs along the water chain}

Law 36-15 of 2016 states that water produced from public sources must be priced per the provisions of the law. A comprehensive overhaul of the tariff system is necessary in the context of reform of regional multi-service distribution (water, sanitation, electricity) to move towards cost recovery for the different uses of water and sanitation services, while considering the ability and willingness to pay of households. The sector would benefit from a review of financial flows throughout the sector (including revenues and the role of surcharges, and working capital requirements caused by the differential in value-added tax between purchases and sales), and a closer look at tariff adequacy for water, sanitation and irrigation services. Other sources of funding for the sector should be explored such as securitization, access to climate funds, creation of a fund project aimed at combating the effects of climate change in order to support operators of the sector, etc. In the case of agriculture, a review of subsidies for drip irrigation is necessary, as it appears that some farmers continue receiving subsidies even after the Offices regionaux de mise en valeur agricole (ORMVAs) has modernized public infrastructure. This would help ensure effective use of scarce subsidies.

\section{b) Reform the regional agricultural development authority, the Offices regionaux de mise en valeur agricole}

The role of the ORMVA today goes well beyond providing water for agricultural use. A review of its activities in line with the institutional review and reform measures highlighted earlier could bring about opportunities to ring-fence certain profitable activities that could attract commercial investment, and better leverage the government subsidies.

\section{Investment opportunities}

There are several bulk water infrastructure projects in the pipeline, as documented in the national water plan. These are shown in Table B.1.

Table B.1 Selected infrastructure development plans for bulk water resources

\begin{tabular}{|l|l|}
\hline \multicolumn{2}{|c|}{ Bulk water infrastructure (Plan National de l'Eau) } \\
\hline Dams & 1,751 million $\mathrm{m}^{3} /$ year in new construction \\
\hline Desalination & 510 million $\mathrm{m}^{3} /$ year in new construction \\
\hline Wastewater reuse & 325 million $\mathrm{m}^{3} /$ year in new capacity \\
\hline Interbasin transfers & $\begin{array}{l}800 \text { million } \mathrm{m}^{3} / \text { year from the basins of Sebou, Loukkos, and Côtiers Méditerranéens } \\
\text { toward Bou Regreg-Chaouia, Oum Er Rbia, and Tensift }\end{array}$ \\
\hline Dam to basin transfers & $\begin{array}{l}50 \text { million } \mathrm{m}^{3} / \text { year from the Sidi Driss major dam in the Oum Er Rbia basin toward } \\
\text { the Tensift basin following the North-Center transfer }\end{array}$ \\
\multicolumn{2}{|c|}{ Source: Ministère de Transport, Plan Route 2030, and Conseil Supérieur de l'Eau et du Climat-10ème Session. } \\
Note: $\mathrm{km}=$ kilometer; $\mathrm{m}^{3}=$ cubic meters.
\end{tabular}

The water sector has certain opportunities for private sector participation, including commercial financing. Most of the opportunities will be in desalination, treated water reuse and irrigation. Table 
B. 2 presents a non-comprehensive list of sector investments that could benefit from private sector participation .

Table B.2 Investment opportunities in the water sector

\begin{tabular}{cl}
$\begin{array}{c}\text { Project or } \\
\text { activity }\end{array}$ & \multicolumn{1}{c}{ Description } \\
\hline PPPs in irrigation & $\begin{array}{l}\text { Following the example of the Guerdane irrigation PPP, several greenfield irrigation PPPs } \\
\text { are in the pipeline or under construction, including Bir Jdid (3,200 hectares south of } \\
\text { Casablanca), Chtouka (15,000 hectares; joint project for ONEE), Saïss (30,000 hectares), } \\
\text { Dakhla (5,000 hectares), Dar Khrofa, and Kadoussa. }\end{array}$
\end{tabular}

PPPs in

desalination

Morocco already has experience in developing small desalination plants. A much larger one now under construction in Chtouka is expected to produce $275,000 \mathrm{~m} 3 /$ day by 2020 (for both potable and agricultural water). More desalination plants are likely to be needed in the years ahead, given the increase in water demand and the fact that conventional water resources are being fully exploited. Plans for a large desalination plant in Casablanca are being prepared by the government.

PPPs for reuse of wastewater from treatment plants
Morocco needs to develop more nonconventional sources of water to enhance water security. Part of the effort involves promoting tertiary treatment in wastewater treatment plants, which would allow treated wastewater to be reused, particularly for agricultural purposes or for watering green areas. The number of wastewater treatment stations has increased from 21 in 2005 to 70 at present, but less than $5 \%$ of treated wastewater is reused. Reuse of wastewater for irrigation could attract private operators possessing the necessary technical and financial means. The approval of the National Plan on Urban and Rural Sanitation and Water Reuse would serve to clarify the policy framework for potential private investors.
Interbasin transfer projects to boost water supply
The government plans two additional inter-basin transfer projects to boost water supply to both Marrakesh (up to 90 million $\mathrm{m}^{3}$ ) and Haouz Centrale. In addition, a north-south inter-basin water transfer project now being planned will consist of a 400-kilometer canal and four tunnels totaling 164 kilometers. The cost through 2030 is estimated at MAD 26-29 billion (USD2.6 billion).

Source: Authors' elaboration.

\section{Transport}

This section presents a number of short- and medium- to long-term measures in the transport sector that could help attract private investment and commercial financing, as well as better manage costs. A list of potential investment opportunities is also presented.

\section{Short-term measures}

\section{a) Increase the operational efficiency of ONCF and consider opening parts of the company's operations to private sector participation}

Some proposals to improve operating efficiency of ONCF include: (i) corporatizing ONCF in the context of a new Railways Law to strengthen its culture of efficiency and accountability, and (ii) pursuing options for increased private sector participation that could take the form of joint-ventures (particularly in the maintenance of rolling stock for instance) and management contracts with international operators to increase the level of operational knowledge and expertise of ONCF. This would help gradually open currently underserved areas for private investment, such as specialized freight transport services through the issuance of railway operations licenses. 


\section{a) Continue to improve the financial viability of AdM, following its recent partial financial restructuring}

Possible solutions to resolve some of the financial challenges faced by AdM noted earlier in this paper include: (i) continuing the balance sheet restructuring of AdM through equity capital infusions, conversion of debt into equity, and/or debt repayment restructuring, particularly refinancing existing debt with relatively short maturities and/or denominated in currencies that are difficult to hedge; (ii) improving selectivity in the choice of new highway projects that would be undertaken with public financing (recent extensions of the network in the lagging regions of the country have been for the most part less commercially successful and financially profitable than older ones); and, (iii) gradually increasing toll fares for specific sections that have been kept below cost recovery or market equilibrium levels for socio-political reasons.

\section{b) Improve the operational efficiency of AdM and the Directorate of Roads of the Ministry of Equipment, Transport, Logistics, and Water}

Possible solutions to improving operational efficiency include: (i) progressively outsourcing an increasing number of tasks to the private sector, including the preventive maintenance of primary, secondary, and tertiary roads (the latter via contracting to SMEs, microenterprises and cooperatives); (ii) adopting methods such as performance-based contracting for the construction and maintenance of highways and primary roads; and (iii) encouraging partnering with international firms to strengthen the level of operational knowledge and expertise within AdM.

\section{c) Improve the financial viability of $\mathrm{ONCF}$}

Possible solutions to improve the financial viability of ONCF include: (i) restructuring the balance sheet, both in terms of assets (for instance, sale of surplus or non-strategic assets, extending concessions or franchising under contract, leasing or reassigning operating assets, joint asset use, sale of operating rights, etc.) and liabilities (for instance, equity capital infusion, debt repayment restructuring, and debt reassignment; (ii) optimizing revenues by adopting a flexible market-based fare policy using yield management principles; and (iii) improving the selectivity in the choice of new railways projects to undertake with public financing.

\section{d) Improve the financial sustainability of the urban transport sector}

Some measures to improve the financial sustainability of the urban transport sector include: (i) increasing the use of contracting the private sector to operate buses under management contracts with increased risk sharing arrangements; (ii) improving fare integration between the various transport modes; (iii) reducing the structural legacy costs that are routinely transferred to new private actors as part of the concession terms (primarily substantial personnel costs, resulting from historic overstaffing of public operators); (iv) ensuring stricter regulation of taxis and other informal operators, especially on the most profitable routes. To mitigate the impact of these actions on the poor, there should be sufficient fiscal sources for urban transport at the municipal level to enable cities to co-finance urban transport projects. The national Urban Transport Fund (FART) is an ideal funding mechanism that can be used to channel central government funding.

e) Sustain the financial viability of the ports authorities, ANP, TMSA, and SODEP Marsa Maroc

The most critical aspect here is to allow selectivity in the choice of new port projects to be undertaken with public financing in order to ensure positive economic, and as far as possible, financial returns. This would ensure that ports authorities can raise unguaranteed finance from the markets. 


\section{f) Sustain the current financial viability of ONDA}

The following actions would maintain the current financial viability of ONDA: (i) improving the selectivity of new airport projects to be undertaken with public financing to ensure positive economic, and as far as possible, financial returns; (ii) readjusting the scope of its areas of interventions so that service delivery is efficient (for instance, by delegating construction or other non-core activities); and (iii) corporatizing ONDA to improve its level of efficiency and accountability and potentially listing a minority stake of the newly formed limited liability company in the Casablanca Stock Exchange, similarly to what has been done in the port subsector.

\section{Investment opportunities}

There are several planned large infrastructure projects in the transport sector, which are highlighted in Table B.3.

Table B.3 Selected infrastructure development plans in transport

\section{Transport infrastructure}

\begin{tabular}{|l|l|}
\hline \multicolumn{2}{|c|}{ Transport infrastructure } \\
\hline Highways Plan & $1,400 \mathrm{~km}$ of new highways and 1,000 km of express routes planned by 2025 \\
\hline Ports Plan & 6 port poles and 4 major new ports to be constructed by 2030 \\
Airports Plan (Ajwae & $\begin{array}{l}\text { Increasing airport capacity to reach 75 million passengers by 2035. Some of the } \\
\text { airports that will benefit include Casablanca Mohammed V airport (construction of } \\
\text { new terminal), Rabat-Sale (construction of new terminal), Marrakesh (new } \\
\text { terminal), Nador (extension of airport), and the southern regional center (Centre de } \\
\text { Contrôle Régional) }\end{array}$ \\
\hline Railways Plan & $\begin{array}{l}2,750 \mathrm{~km} \text { of new conventional railway lines and 1,500 km of high-speed railway } \\
\text { lines }\end{array}$ \\
\hline
\end{tabular}

The transport sector has several opportunities for private sector participation, including commercial financing. Most of the opportunities will be in the ports and airports sectors but some segments of roads and railways also show promise for private sector participation. Table B.4 presents a non-comprehensive list of sector investments that could benefit from private sector participation.

Table B.4 Investment opportunities in the transport sector

\begin{tabular}{|c|c|}
\hline Project or activity & Description \\
\hline Roads & $\begin{array}{ll}\text { - } & \text { Highway linking Casablanca to Rabat (planned), parallel to the existing one } \\
\text { - } & \text { Highway linking Tanger to Tétouan (planned) } \\
\text { - } & \text { Highway linking Marrakech to El Kelaâ des Sraghna (planned) } \\
\text { - } & \text { Highway linking Guercif to Nador (planned) }\end{array}$ \\
\hline Railways & $\begin{array}{ll}\text { - } & \text { Greenfield passenger railways lines (linking Tanger and Tetouan, Khouribga } \\
\text { and Beni Mellal, and Marrakech and Agadir, etc.) } \\
\text { - } \quad \text { Greenfield passenger and freight railway line (linking Nador and Selouane) } \\
\text { - } \quad \text { Greenfield rolling stock maintenance workshops } \\
\text { - } \quad \text { Greenfield railway-linked dry ports (in Oujda, Tangier, Marrakech, etc.) } \\
\text { - } \quad \text { New container/freight and logistics services (from/to Tanger Med, from/to } \\
\text { Nador West Med, etc.) } \\
\text { - Potential partial divesture of existing business units and assets (including } \\
\text { real estate) }\end{array}$ \\
\hline Urban transport & $\begin{array}{l}\text { - Renewal of rolling stock in Greater Rabat in the context of the new bus } \\
\text { concession (concession awarded, to start in 2018) }\end{array}$ \\
\hline
\end{tabular}


- $\quad$ Renewal of rolling stock in Greater Casablanca in the context of the new bus concession (not yet awarded, concession to start in 2019)

- Renewing bus rolling stock in Marrakesh in the context of the new concession (not yet awarded, concession to start in 2019)

- $\quad$ Greenfield Bus Rapid Transit projects (line 1 and 2) in Agadir (planned)

- Greenfield tramways projects (line 3 and 4) in Casablanca

- Extension of the existing tramway network in Rabat

- Parking structures in Casablanca

\begin{tabular}{lll}
\hline Ports & - & Operational concession of Nador West Med greenfield port (under \\
& & construction) \\
& - & BOT of Kénitra Atlantique greenfield port (planned) \\
& BOT of Jorf Lasfar port extension (planned) \\
\hline Airports & - & Casablanca airport extension (planned) \\
& - & Tangier airport extension (planned) \\
& - & Marrakech greenfield airport (planned) \\
& (planned)
\end{tabular}

Source: Authors' elaboration.

\section{Electricity}

This section presents a number of short-term and medium- to long-term measures in the electricity sector that could help attract private investment and commercial financing, as well as better manage costs. A list of potential investment opportunities is also presented.

\section{Short-term measures}

\section{a) Operationalize the regulator}

To support the renewable energy transition, the government created through Law 48-15 of 2015, a new independent regulatory authority, the Autorité Nationale de Régulation de l'Eléctricité (ANRE). Although ANRE's president has been appointed in August 2018, the regulatory authority has not yet been fully established. Given the previous lag in instituting the agency (an idea first proposed in the 1990s), it is important that the government moves quickly to empower the regulator the necessary powers and statutes. For ANRE to become fully operational, the Ministry of Energy Mines and Sustainable Development (MEMDD) needs to nominate by decree the three key members of the council, the legal, financial and technical energy experts. A well-structured sector with an autonomous and independent regulator could increase the attractiveness of the electricity sector for private investors. It is important to ensure adequate competition in energy production, transparency, and a functional market for electricity sales, while progressively lessening the public burden of renewable energy financing. The main task of ANRE will be to establish and oversee the conditions and rules governing integration into the grid of renewable energy investments. While ANRE's initial objectives will be modest, these could be broadened over time as the agency builds in-house capacity.

\section{b) Role rationalization}

The energy sector has several actors: The Ministry of Energy, Mines, and Sustainable Development (titular authority), Ministry of Interior (an authority in the distribution segment), ONEE, the renewable energy agency (MASEN), Agence Marocaine de l'Efficacité Énergétique (AMEE), and Société d'Investissement Energétique (SIE). Institutional rationalization and role clarification is needed to avoid overlaps in responsibilities. For instance, the electricity distribution segment is overseen by two different ministries (Ministry of Energy and Ministry of Interior) whose activities are not always 
coordinated. The position of the government with respect to the framework laid out in Law 13-09 and the role of stakeholders, particularly those of MASEN and ONEE, therefore needs to be clarified by decree. The reform of that Law is currently ongoing, which might address this issue. The transfer of assets between ONEE and MASEN, as outlined in the article 2 of Law 38- is ongoing within the scope of a specific agreement that identifies assets to transfer, transfer procedures and modalities, etc.

\section{c) Pursue reforms to stimulate private investment in the small and medium size renewable energy market}

The current economics of solar and wind energy makes it possible to produce energy at lower costs. In addition to the development of the Integrated Wind Program and theSolar Plan underway, the government aims to allow private operators to sell renewable energy directly to consumers. A set of three policy actions are recommended to enable decentralized generation and the liberalization medium voltage for private operators, low voltage liberalization for classical household consumers, and to both medium and low voltages. These proposed policies involve:

(i) Completing Decree 2-15-772 (under Law 13-09 on renewable energy) to release the ministerial order setting a threshold in GWh for the level of decentralized renewable energy generation to be allowed to feed into the national grid.

(ii) Completing modalities to allow the opening of the electricity market for low voltage renewables provided for under Law 58-15, which has not yet been operationalized.

(iii) Completing law 58-15, which would allow the sale of energy surpluses for all voltage levels.

Supporting the successful implementation of decentralized renewable power generation would contribute to: (i) increased reliability and security of the national electricity supply by relieving distribution and transmission congestion; (ii) reduced emissions; and (iii) improved quality of electricity supply to end users.

\section{Medium- to long-term measures}

\section{a) Operationalize the Energy Efficiency Law}

The "price signal," one of the strongest behavioral change factors in energy efficiency economics, is now a reality in Morocco, as tariffs are increasingly reflecting real power costs thanks to the recent elimination of fossil-fuel subsidies in the power sector. In this context, the government of Morocco is well positioned to operationalize its Energy Efficiency Law 47-09 and to stimulate a new market for energy service companies (ESCOs). Enabling a market for private can lead to a greener and more efficient energy landscape in Morocco, both in the areas of domestic consumption and for the industrial, tourism and agricultural sectors.

\section{Investment opportunities}

The energy sector has several opportunities for private sector participation, including commercial financing. Most of the opportunities will be in electricity generation and in the gas to power project. Table B.5 presents a non-comprehensive list of sector investments that could benefit from private sector participation. 
Table B.5 Investment opportunities in the energy sector

\begin{tabular}{|c|c|}
\hline Project or activity & Description \\
\hline $\begin{array}{l}\text { LNG Gas to Power } \\
\text { Project (liquefied } \\
\text { natural gas plus } \\
\text { combined-cycle gas } \\
\text { turbine ) }\end{array}$ & $\begin{array}{l}\text { The project, which is estimated to cost USD } 4.6 \text { billion, will comprise: a maritime jetty } \\
\text { north of the port of Jorf Lasfar to receive and unload LNG tankers; an onshore LNG } \\
\text { regasification unit; LNG storage tanks; a } 400 \mathrm{~km} \text { gas pipeline linking the LNG terminal } \\
\text { to the Maghreb-Europe pipeline; and, two new combined-cycle gas turbine power } \\
\text { plants at Jorf Lasfar and Dhar Doum with a combined capacity of } 2,400 \text { MW. The } \\
\text { project, now in the feasibility/structuring stage, will be developed as a single package } \\
\text { under a build, own, operate and transfer model. Financial close is expected in } 2019 \text {. }\end{array}$ \\
\hline $\begin{array}{l}\text { Ifahsa STEP } \\
\text { (Hydro) }\end{array}$ & $\begin{array}{l}\text { Pumped hydro storage project at an early stage of development. Capacity: } 300 \mathrm{MW} \text {. } \\
\text { Commissioning date to be determined. }\end{array}$ \\
\hline $\begin{array}{l}\text { El Menzel STEP } \\
\text { (Hydro) }\end{array}$ & $\begin{array}{l}\text { Pumped hydro storage project at an early stage of development. Capacity: } 300 \mathrm{MW} \text {. } \\
\text { Commissioning date to be determined. }\end{array}$ \\
\hline $\begin{array}{l}\text { Noor Midelt Phase I } \\
\text { (Solar Hybrid) }\end{array}$ & $\begin{array}{l}\text { Phase of a hybrid solar project sponsored by MASEN. The plant will be developed, } \\
\text { built, and operated by a private investor, with MASEN acting as the sole offtaker. Its } \\
\text { PPP structure will be similar to that of Ouarzazate and will include an IBRD loan of } \\
\text { USD200 million. It will be mostly publicly financed. Capacity: } 800 \mathrm{MW} \text {. Total cost: } \\
\text { USD2.2 billion. Commissioning date to be determined. }\end{array}$ \\
\hline Noor PV II & 800 MW (Solar PV). Commissioning date to be determined. \\
\hline $\begin{array}{l}\text { Morocco-Portugal } \\
\text { Power } \\
\text { Interconnection }\end{array}$ & $\begin{array}{l}\text { REN and ONEE were mandated by the Governments of Portugal and Morocco to } \\
\text { submit draft proposals with a view to constructing a 200-kilometer electric cable to link } \\
\text { the two countries' grids. }\end{array}$ \\
\hline
\end{tabular}

Source: Authors' elaboration.

\section{Information and communication technology (ICT)}

This section presents a number of short-term and medium- to long-term measures in the ICT sector that could help attract private investment and commercial financing, as well as better manage costs. A list of potential investment opportunities is also presented.

\section{Short-term measures}

\section{a) Strengthen the national policy framework}

Formal adoption of Morocco Digital, the national strategy for digital economy , pending since 2014, would contribute to a digital transformation in Morocco. Institutionally, a new agency responsible for implementing the state strategy for developing the digital economy and the disseminating digital tools to citizens, the Agence du Développement Digital (ADD), was created at the end of 2017. The ADD is currently developing general guidelines for future digital development in Morocco. These guidelines are articulated around several pillars of the Morocco Digital strategy, which include the establishment of digital infrastructure that are a prerequisite for the country's digital transformation. ADD is in the process of setting up the organization and acquiring the appropriate tools for an operational launch of different sites from September 2019. In addition, the new general guidance note from government (NOG 2019-2022) scheduled to be adopted in 2019 should promote the opening of the market and strengthen the regulation of essential infrastructure and large operators. 


\section{b) Strengthen the legal and regulatory framework of the sector}

In order to facilitate the entry of new players into the fixed broadband market, the parliament adopted an amendment (through Law 121.12, for which decrees remain to be adopted in 2019) to the code 24/96 telecoms but this does not include provisions to clarify and facilitate the terms relating to (i) the granting of licenses / authorizations to Internet Service Providers on the market allowing them to deploy their own infrastructure; and (ii) granting licenses / authorizations to Wholesale Infrastructure Operators authorizing them to deploy their own infrastructure. So the government should first adopt another amendment to the telecom code 24/96 incorporating these aspects, and adopt the implementing decree of this amendment which should specify the modalities Licensing / Authorization for Internet Service Providers and Wholesale Operators infrastructure authorized to deploy their own infrastructure.

\section{c) Optimize the use of existing digital infrastructures owned by SOEs through infrastructure sharing}

Morocco has an untapped opportunity to leverage the public fiber optic networks built by SOEs, such as ONCF and ONEE. The networks built by these companies for their own needs have excess capacity, and ONCF and ONEE are legally authorized to commercialize this capacity subject to regulation. These networks $(1,600 \mathrm{~km}$ of fiber for ONCF and 7,000 km for ONEE in 2016) represent a strategic asset for the development of the digital economy. In order to optimize the use of digital infrastructures public, the parliament has already adopted an amendment (through Law 121.12) to the telecom code 24/96 allowing the submission of alternative infrastructure operators to the regulation of telecommunications for the marketing (on the telecommunications market) of their digital infrastructure surpluses under open and non-discriminatory access conditions. These public digital infrastructures are critical to the emergence of a wholesale market of regulated digital infrastructure.

In the medium term, and in the event that the regulation does not bear fruit, the government could consider bringing together all of the public digital infrastructure in a society of assets and delegate the operation of these infrastructures to the private sector under a contract PPP type (generally concession or leasing). International experiences (many exist in Europe and in France in particular; the case of SDIN in Mauritania or ADIE in Senegal constitute other regional examples) have shown the interest of this type of practice which allow the State to benefit from the expertise of the private sector in infrastructure management and generate significant budgetary revenue for public finances. The private operator operating public infrastructure on behalf of the State is required to limit itself to the marketing of infrastructure on the wholesale market and respecting the principles of open and non-discriminatory access to so as to promote competition.

\section{Medium-to-long-term measures}

\section{a) Strategic use the Universal Service Fund (USF)}

Morocco developed the USF to finance broadband infrastructure in underserved areas where private investment is lacking. It is funded by 2 percent of the annual total turnover of telecom operators, and ANRT manages and oversees the fund. To date, USF has only initiated six projects since inception in 2005 , mostly in the education sector. None of these projects funded at scale the deployment of broadband infrastructure in neglected areas. About USD 288 million is still available in the USF, and there are indications that ANRT has launched a national call for tenders to finance broadband development in underserved areas but no public information is available to confirm this. Some considerations to make the USF more impactful include an annual audit of the fund's activities and the development of a universal access strategy aimed at eliminating the digital divide. 


\section{a) Stimulate demand for broadband by improving consumer readiness and increasing the availability of relevant local content}

Some demand side measures to boost demand for broadband services would also help move Morocco towards an increasingly digital economy. Activities could include vocational training in areas that are likely to create future jobs, and the development of digital services in e-education, e-health, egovernment, mobile banking, and other online services.

\section{Investment opportunities}

The ICT sector has some potential opportunities for private sector participation, including commercial financing. Table B.6 presents a non-exhaustive list of potential investment opportunities that could benefit from private sector participation.

Table B.6 Investment opportunities in the ICT sector

\begin{tabular}{ll}
\hline \multicolumn{1}{c}{ Project or activity } & \multicolumn{1}{c}{ Description } \\
\hline PPPs to develop broadband infrastructure & $\begin{array}{l}\text { PPP schemes can support broadband deployment to } \\
\text { underserved parts of the country }\end{array}$ \\
\hline Investment in a new submarine cable & $\begin{array}{l}\text { Morocco's location provides ample scope for } \\
\text { investment in submarine cables linking Morocco with } \\
\text { Europe and West Africa. Morocco can exploit its } \\
\text { location to become a data hub and an important IP transit } \\
\text { route. }\end{array}$ \\
\hline $\begin{array}{l}\text { Investment in backbone and access networks by } \\
\text { newly licensed wholesale operators and internet } \\
\text { service providers. }\end{array}$ & $\begin{array}{l}\text { More investments are needed to extend broadband } \\
\text { infrastructure and improve access to it. }\end{array}$ \\
\hline $\begin{array}{l}\text { Investments in other telecom infrastructure such as } \\
\text { telecom towers, data centers, and internet } \\
\text { infrastructure and service companies }\end{array}$ & $\begin{array}{l}\text { Infrastructure sharing (e.g. independent tower } \\
\text { companies) will help operators monetize assets and will } \\
\text { improve coverage of 4G (and soon 5G) networks. Data } \\
\text { centers and internet infrastructure companies (co- } \\
\text { location, cloud computing, web security, data analytics) } \\
\text { will improve customer experience, meet corporate } \\
\text { demand, allow Morocco to engage in IT exports, and } \\
\text { contribute to increasing employment. }\end{array}$
\end{tabular}




\section{Appendix C. Methodology used to estimate infrastructure spending scenarios}

This appendix provides a summary of the methodology used to estimate future infrastructure investment needs highlighted in Section 3.3. Further details are available in a background paper prepared as part of the research for this report.

Investment refers to expenditure intended to increase the capacity of infrastructure service provision, while renewal CAPEX refers to expenditure needed to maintain service and operate an infrastructure asset at the level of service for which it was designed. With these definitions and international unit costs, a scenario analysis was developed to obtain a rough idea of future spending needs on new and renewal CAPEX, which are computed as follows:

$$
\begin{gathered}
\text { Investment }=\text { variation of stocks } * \text { unit costs } \\
\text { Renewal CAPEX }=\text { stocks } * \text { unit costs } * \text { utilization rate }
\end{gathered}
$$

Renewal CAPEX may be major, periodic, or minor, and is linked to the level of investment, though calibrated to reflect the specificities of each sector. These assumptions are summarized in table C.1.

Table C.1 Average international unit costs

\begin{tabular}{|l|c|c|}
\hline \multicolumn{1}{|c|}{ Infrastructure subsector } & Unit & Unit costs (USD) \\
\hline Paved roads & Kilometer & $1,000,000$ \\
\hline Unpaved roads & Kilometer & 51,000 \\
\hline Rails & Kilometer & $1,200,000$ \\
\hline Ports & TEU & 360 \\
\hline Mobile line & Line & 160 to $103^{1}$ \\
\hline Broadband & Line & 300 \\
\hline Electricity installed capacity & kW & 250 \\
\hline Electricity connection & Person & 150 \\
\hline Sanitation facilities & Person & capacity, \\
\hline
\end{tabular}

Source: For ICT prices, GSMA (2015) and OECD (2005); for electricity installed capacity,

Pinto de Mouraa et al. (2016); and for the rest, Ruiz-Nuñez and Wei (2015).

Note: Water and sanitation costs include only structural assets that provide access to the network, not wastewater treatment and water production.

The following infrastructure variables are used for the low- and high-growth scenarios:

- Transport: kilometers of paved and unpaved roads, kilometers of rails, and capacity of ports

- Electricity: gigawatts generated and access rates

- Water and sanitation: access to water and access to sanitation

- Information and communication technology (ICT): mobile lines per capita and broadband connections per 100,000 inhabitants

The following scenarios were prepared:

(i) A scenario based on the 30-year average (1985-2015) or "Baseline Scenario": The annual change in infrastructure stocks over the period 1985-2015 multiplied by the international unit costs of infrastructure stocks in 2016.

(ii) A scenario targeting the $40^{\text {th }}$ percentile of infrastructure stocks in upper middle-income countries by 2030 or "High Growth Scenario": The yearly evolution of infrastructure stocks 
is computed for Morocco to reach upper-middle-income countries' ${ }^{56} 40^{\text {th }}$ percentile of infrastructure stocks by 2030, as assessed in 2015. This figure is again multiplied by 2016 international unit costs for the construction of infrastructure.

These estimates suggest a range of expenditure needs from 11.5 percent to 18.3 percent of GDP (capital, maintenance and operating costs). The analysis was done by examining future investment and maintenance costs, with assumed operating costs (OPEX) of 4 percent based on the difference between actual spending on operating and maintenance and estimates of maintenance only shown in Table 3.1 and 3.2 of the main report, respectively ${ }^{57}$. Table C.2 presents the results of this scenario analysis.

Table C.2 Scenarios for future infrastructure spending (\% of GDP)

\begin{tabular}{|l|c|c|c|c|}
\hline & $\begin{array}{c}\text { Investment } \\
\text { (CAPEX) }\end{array}$ & Maintenance & OPEX & Total \\
\hline Baseline growth scenario & 3.4 & 4.1 & 4.0 & 11.5 \\
\hline High growth scenario & 9.9 & 4.4 & 4.0 & 18.3 \\
\hline
\end{tabular}

The sectoral expenditure estimates underpinning the numbers above are presented in Table C.3:

Table C.3 Scenarios for future infrastructure spending by sector (\% of GDP)

\begin{tabular}{|l|c|c|c|c|}
\hline \multirow{2}{*}{} & \multicolumn{3}{|c|}{ CAPEX } & \multicolumn{2}{c|}{ Maintenance } \\
\cline { 2 - 5 } & $\begin{array}{c}\text { Low } \\
\text { growth }\end{array}$ & $\begin{array}{c}\text { High } \\
\text { growth }\end{array}$ & $\begin{array}{c}\text { Low } \\
\text { growth }\end{array}$ & $\begin{array}{c}\text { High } \\
\text { growth }\end{array}$ \\
\hline Transport & 1.6 & 3.56 & 2.70 & 2.60 \\
\hline ICT & 0.6 & 0.00 & 0.37 & 0.52 \\
\hline Electricity and W\&S & 1.3 & 6.3 & 1.0 & 1.3 \\
\hline TOTAL & $\mathbf{3 . 4}$ & $\mathbf{9 . 9}$ & $\mathbf{4 . 1}$ & $\mathbf{4 . 4}$ \\
\hline
\end{tabular}

These are top-down simulations using international figures on unit costs. Ideally, the investments included in all sectoral plans would be combined to present a more accurate picture of actual investment needs; however, such an exercise was not possible within the scope of this analysis.

\footnotetext{
56 Countries benchmarked for the high growth scenario are: Malaysia, Bulgaria, Turkey, Brazil, Mexico, Colombia, Peru, Ecuador and Algeria. Tunisia is also included for comparison of Maghreb countries although it has less developed infrastructure than Morocco.

57 It is recognized that the figure of $4 \%$ is not based on an assessment of actual operating costs
} 